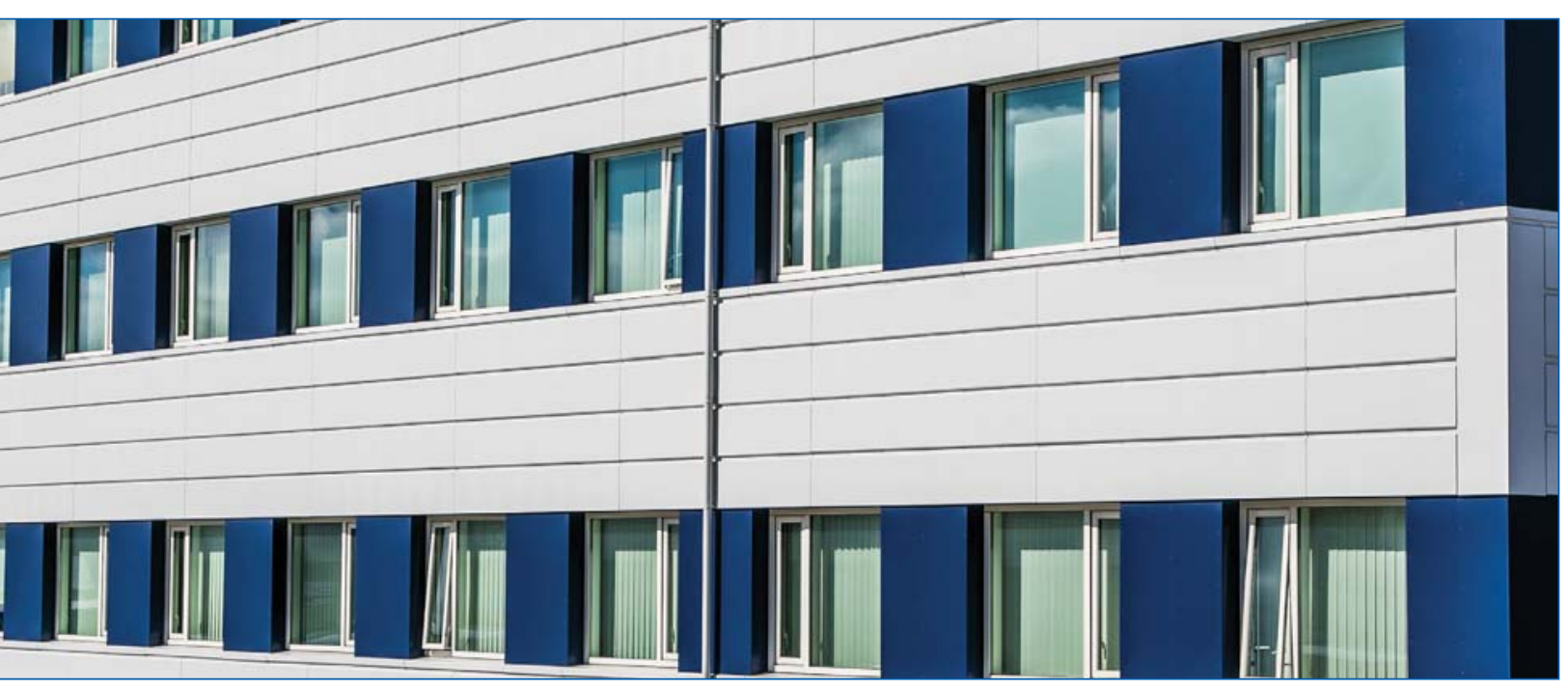

$$
\begin{aligned}
& \text { ÁRSSKÝRSLA } \\
& \text { 2014-2015 }
\end{aligned}
$$

Krabbameinsfélagið 


\section{Ársskýrsla 2014-2015}

Lögð fram á aðalfundi

Krabbameinsfélags Íslands

9. maí 2015

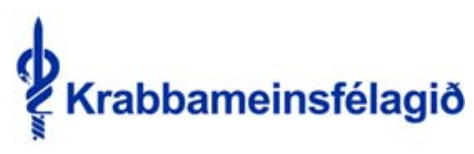




\section{Efni}

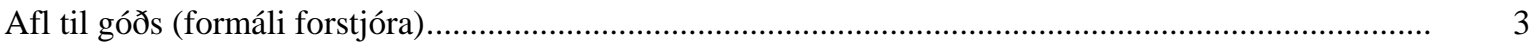

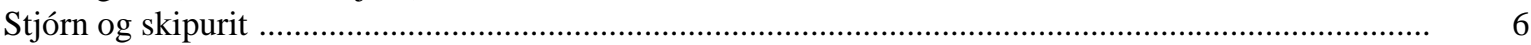

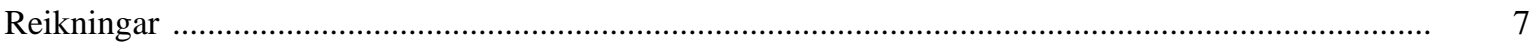

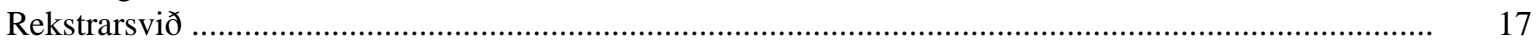

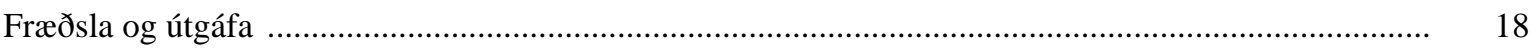

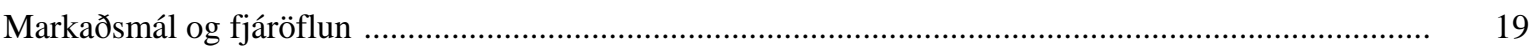

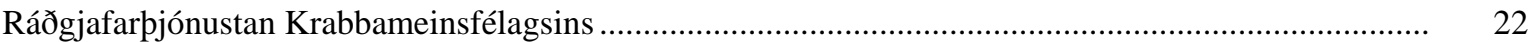

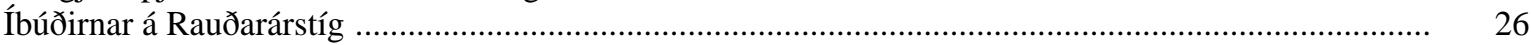

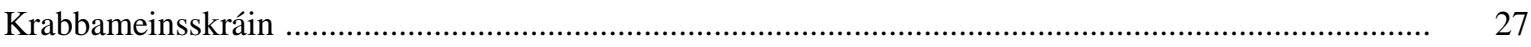

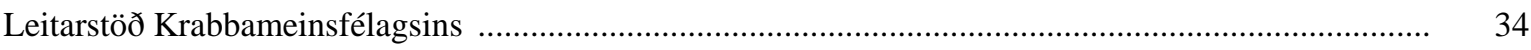

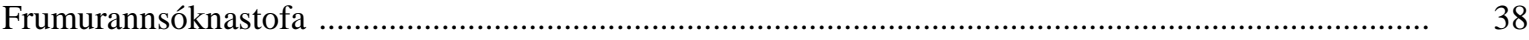

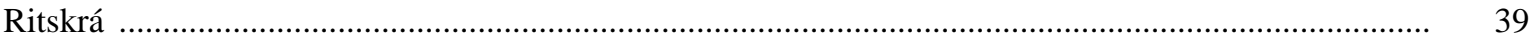

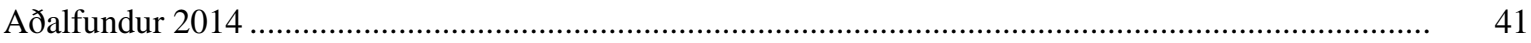

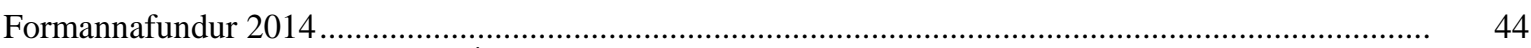

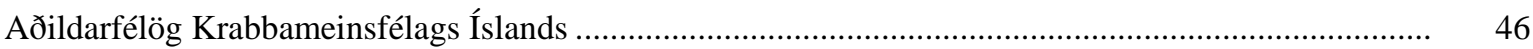

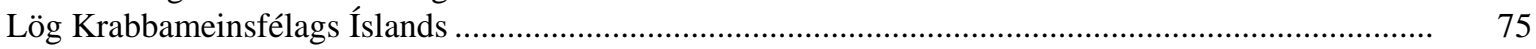




\section{Afl til góðs}

Starfsárið milli aðalfunda árin 2014 og 2015 hefur einkennst af framsækni og vilja til góðra verka, bæði hjá starfsfólki og félagsmönnum. Pannig hafa margvíslegar breytingar litið dagsins ljós og aðrar undirbúnar sem ætlað er að auka og bæta pjónustu við pá sem til okkar purfa að sækja.

Fræðsla til almennings er eitt af lykilhlutverkum Krabbameinsfélagsins. Ráðinn hefur verið læknir sem er í doktorsnámi í lýðheilsuvísindum í starf fræðslustjóra og hefur hann fag- og fræðsluráð sér til samstarfs og ráðgjafar. Lögð er áhersla á að efla fræðslu á netinu og á samfélagsmiðlum og hefur tekist vel til, efnið er skoðað og sótt meira en áður. Dá hefur almenningsfræðslan í auknum mæli farið fram í fjölmiðlum og framundan er reglubundin samvinna Krabbameinsfélagsins og fjölmiðla um kynningar og upplýsingamiðlun. Fræðslustarf fer nú fram á vegum Ráðgjafarpjónustunnar, fræðslustjóra (fag- og fræðsluráðs), markaðsdeildar, Leitarstöðvarinnar og Krabbameinsskrárinnar. Á grundvelli samnings Krabbameinsfélags Íslands og Krabbameinsfélags Reykjavíkur er unnið að margvíslegum fræðsluverkefnum og kemur framkvæmdastjóri Reykjavíkurfélagsins að fjölmörgum fræðsluverkefnum félagsins. Mikil samvinna er milli allra pessara starfseininga. Forvarnaverkefnin eru mörg og tengjast oft fræðslu og kynningarstarfi. Sem dæmi mætti nefna að gefin eru út skilaboð um heilbrigða lífshætti og peim dreift víða. Við tökum pátt í starfi Evrópusamtaka Krabbameinsfélaga (European Cancer Leagues) og leggjum með peim áherslu á að kynna viðvaranir sem unnar hafa verið á vegum peirra samtaka og alpjóðastofnana; European Code Against Cancer.

Leitarstarfið hefur tekið breytingum á árinu. Skipulagsbreytingar á skilgreiningum markhópa sem boðaðir eru í leit að leghálskrabbameinum og gerðar voru í ársbyrjun 2014 hafa ekki haft neikvæð áhrif á mætingu. Breytingin hafði í för með sér fækkun sýna sem komu til skoðunar hjá frumurannsóknastofunni. Árvekniátak í bleika mánuðinum (,„Erum við að leita að pér?”) hafði góð áhrif á mætingu og nýtt fræðslumyndband var líka gagnlegt. Í ársbyrjun 2015 voru í fyrsta sinn send leghálsvökvasýni til greiningar á HPV (veira sem valdið getur leghálskrabbameini) til Svípjóðar. bessi tilraun tókst vel og gert er ráð fyrir að HPV-greiningar verði nú páttur í leitarstörfunum og taki jafnvel við af smásjárskoðun á PAP-strokum á næstu árum eins og próunin er í nágrannalöndum okkar. Töluverð vandamál blöstu við um tíma vegna skorts á röntgenlæknum til starfa við leit að krabbameinum í brjóstum, sérstaklega til pess að sinna klínískri leit, p.e. konum sem purfa frekari skoðunar með en hópleit gefur kost á. Detta leystist með pví að tveir röntgenlæknar sem starfa á Landspítala sinna klínískri leit í Skógarhlíð en gert er ráð fyrir að bessi páttur brjóstaleitarinnar færist síðar yfir á Landspítala.

Hópleit að ristilkrabbameinum parf að komast sem fyrst til framkvæmda að mati Krabbameinsfélagsins sem undanfarin ár hefur lagt áherslu á pessa forvörn með margvíslegum hætti. Í desember sl. veitti tryggingarfélagið Okkar líf félaginu veglegan styrk til að vinna аð undirbúningi skipulegrar leitar að ristilkrabbameini. Í rekstraráætlun félagsins fyrir árið 2015 var gert ráð fyrir (að höfðu samráði við ráðuneyti) að hafinn yrði undirbúningur að slíkri hópleit. Ráðinn var sérfræðingur í meltingarlækningum sem verkefnisstjóri og á vormánuðum 2015 fór ráðuneytið pess á leit við Krabbameinsfélag Íslands að pað gerði tillögur að verkaskiptingu við undirbúning pessarar hópleitar. Tillögum hefur verið skilað og hefur verið myndaður samstarfsvettvangur ráđuneytis, Embættis landlæknis og Krabbameinsfélagsins um næstu skref.

Ráðgjafarpjónustan er rekin að mestu leyti fyrir sjálfsaflafé Krabbameinsfélagsins, en pjónustan móttók nokkra góða styrki á starfsárinu (sjá skýrslu Ráðgjafarpjónustunnar). Starfsemin fer vaxandi ár frá ári. Opnast hafa möguleikar á að efla stuðning og leiðbeiningar gegnum síma og á netinu og bundnar eru vonir við að pessi pjónusta gagnist vel. Ráðgjafarbjónustan hefur mjög víðtækt hlutverk og vinnur náið með öðrum starfseiningum. Nauðsynlegt er að fjölga starfsmönnum par á árinu 2015 og að auka við húsnæðið. Hvoru tveggja nýtur stuðnings stjórnar og er í skoðun.

Krabbameinsfélagið beitir sér fyrir margvíslegum hagsmunum sjúklinga og aðstandenda peirra svo og almennum verkefnum sem tengjast velferð almennings og krabbameinum. Á pessu starfsári voru gefnar út tvær skýrslur, sem vænst er að komi að gagni, hvor með sínum hætti. Skýrsla um endurhæfingu fyrir 
krabbameinssjúklinga var unnin í samvinnu við fjölmarga pá sem starfa á pessu sviði og er unnt að leggja hana til grundvallar stefnumótunar í pessum málaflokki. Skýrslan hefur verið kynnt ítarlega og er nú til skoðunar í velferðarráðuneytinu. Pá var gefin út ný og endurbætt skýrsla um hagnýtar upplýsingar fyrir krabbameinssjúklinga og var henni dreift víða og er hún mjög til hagsbóta fyrir alla pá sem fjalla um pessi mál, starfsmenn heilbrigðisbjónustu jafnt sem sjúklinga. Krabbameinsfélagið hefur tekið virkan pátt í opinberri umræðu um málefni sjúklinga, m.a. í tengslum við átök og kjaradeilur heilbrigðistarfsmanna, greiðslupátttöku sjúklinga í heilbrigðispjónustu og ýmis mál sem tengjast gæðum pjónustunnar.

Tekist hefur á pessu ári að safna stofnfjármagni til vísindasjóðs Krabbameinsfélagsins frá Krabbameinsfélaginu, aðildarfélögum pess og úr sjóðum sem verið hafa í vörslu félagsins, Kristínarsjóði og Ingibjargarsjóði. Upphæð stofnfjár er um 200 milljónir króna. Drög að starfsreglum sjóðsins liggja fyrir. Sjóðurinn mun efla möguleika íslenskra rannsakenda til að stunda vísindastörf og er hans beðið með nokkurri ópreyju. Væntanlega verða styrkir auglýstir til umsóknar með haustinu.

Vísindastarf á vegum félagsins hefur að vanda mest verið á vegum Krabbameinsskrárinnar. Litið er svo á að fjárframlög félagsins til skrárinnar séu fyrst og fremst til að styðja við rannsóknir á vegum hennar, en fjárveiting á fjárlögum greiði kostnað við skráningu meinanna. Heilsusöguverkefnið, samstarfsverkefni Háskóla Íslands og Krabbameinsfélagsins sem rekið er í kjallaranum í Skógarhlíðinni hefur gengið vel, og er verið að vinna úr rannsóknargögnum. Fjármagn vantar til að unnt sé að halda áfram gagnasöfnun með peim krafti sem upphafleg áform gerðu ráð fyrir.

Íslendingar eiga Nordic Cancer Union (NCU) pakkir að gjalda fyrir margvíslegan stuðning á liðnum árum. Á pað ekki síst við um styrki veitta til vísindastarfa, en líka um ýmiss konar ráðgjöf og próunarverkefni sem leitt hafa til árangursríkari verka Krabbameinsfélagsins. Nú er komin röðin að Íslandi að leiða starf NCU og tók forstjóri Krabbameinsfélagsins við formennsku pess í ársbyrjun. Formaður stjórnar Krabbameinsfélags Íslands verður einnig virkur í starfi stjórnar NCU og margir starfsmenn félagsins munu leggja af mörkum vinnu til pessa verkefnis næstu prjú árin.

Flestar bjóðir eiga sér sína krabbameinsáctlun. Árið 2011, á 60 ára afmæli Krabbameinsfélagsins, lofaði ráðherra heilbrigðismála að við Íslendingar fengjum okkar áætlun. Verkið hefur sóst seint, en á pessu starfsári var pað tekið fastari tökum af hálfu ráðuneytisins og liggja nú fyrir drög að krabbameinsáætlun fyrir Ísland, sem vænst er að verði kynnt fljótlega. Krabbameinsfélagið hefur lagt vinnu í pessa áætlun og bindur miklar vonir við hana.

Framtíðarlífeyrisskuldbindingar Krabbameinsfélagsins hafa verið til skoðunar hjá fjármálaráðuneytinu sl. ár ásamt sambærilegum skuldbindingum annarra sjálfseignarstofnana og frjálsra félagasamtaka, sem hafa samninga um rekstur bjónustu við stjórnvöld. Samið var við mörg hjúkrunarheimili en loforð liggur fyrir um að næst verði rætt við Krabbameinsfélagið. Bið eftir peim viðræðum er orðin löng en fyrir liggur ítarleg og vel rökstudd greinargerð frá Krabbameinsfélaginu sem kynnt hefur verið fjármálaráðuneytinu og verður lögð til grundvallar pessum viðræðum.

Ánægjulegt hefur verið að fylgjast með peim breytingum sem húsið í Skógarhlíð hefur tekið, en verklok vegna klæðingar hússins og ýmissa endurbóta voru nú á vordögum. Dráttur á verklokum kemur til af pví að um var að ræða mun viðameiri viðgerð á húsinu en gert hafði verið ráð fyrir, sérstaklega vegna mikils raka og fúa víða. Grunur vaknaði um myglusvepp á nokkrum stöðum í húsinu. Vegna jákvæðrar afstöðu starfsfólks til pessara viðgerða og tillitsemi verktaka við starfsemina tókst að ljúka pessu verki án pess að starfsemin truflaðist að ráði. Er pað samdóma álit starfsmanna að mjög vel hafi tekist til alla staði og að mun betra sé að vera og vinna í húsinu.

Að vanda hefur samvinna og samskipti við stjórnvöld verið með margvíslegum hætti og hefur félagið ritað umsagnir um pingmál og komið á framfæri sjónarmiðum sínum um mál sem tengjast krabbameinum.

Markaðsdeild hefur að vanda borið ábyrgð á fjáröflun og markaðsmálum félagsins og jafnframt komið að ýmsum kynningarmálum og almannatengslamálum. Velunnarakerfi félagsins hefur verið tekið til skoðunar og nú fá allir velunnarar sem hafa gefið okkur netföng sín kveðjur og upplýsingar mánaðarlega um 
starfsemina. Fjáröflunar- og árvekniátök í október og í mars hafa vakið gríðarlega athygli og langt útfyrir landssteinana. Sérstaklega hefur árveknin verið öflug og bæði október átakið „,Erum við að leita að pér?” og marsátakið með áherslu á leit að ristilkrabbameinum, m.a. í „,Dillibossamyndbandi”, hafa vakið verðskuldaða athygli. Fjáröflun á vegum markaðsdeildar er undirstaða margra góðra verka hjá Krabbameinsfélaginu og pví mjög mikilvægt að vel til takist. Á árinu hefur gefist kostur á að vinna með nokkrum fyrirtækjum að stærri verkefnum og pannig að tryggja fjármagn til peirra, og gerir petta félaginu kleyft að sinna verkefnum af meiri styrk en ella.

Fjölmiðlaumfjöllun á árinu hefur verið óvenjulega mikil og oft er kallað eftir áliti starfsmanna Krabbameinsfélagsins auk pess sem fræðsla og árvekni á vegum félagsins hefur komið oft til umfjöllunar. Félagið lét nú í vor gera fjölmiðlagreiningu sem varpar ljósi á umræðuna undanfarin misseri. Umfjöllunin hefur í langflestum tilvikum verið jákvæð í garð félagsins og mælist aðeins brot fjölmiðlaumfjöllunar neikvæð í garð Krabbameinsfélagsins. Í peim tilvikum hafa forsvarsmenn félagsins leitast við að svara með málefnalegum hætti og notað tækifærið til að gera grein fyrir störfum og starfsemi félagsins.

Samskipti fara nú fram í vaxandi mæli á félagsmiðlunum og einnig er upplýsingarveita á heimasíðu félagsins notuð mikið. Forstjóri sendir öðru hverju fréttir til félaga að vanda og haldnir eru reglubundnir starfsmannafundir í Skógarhlíðinni.

Aðildarfélög Krabbameinsfélagsins breytast og próast ár frá ári. Starfið er misjafnt eftir aðstæðum á hverjum stað og ekki síst eftir pví hvort reknar séu pjónustumiðstöðvar á vegum félaganna. Ljóst er að pjónustuskrifstofurnar geta eflt starfsemina og verið mikill stuðningur. Á aðalfundi 2014 voru kynntar niðurstöður könnunar meðal aðildarfélaganna á viðhorfum peirra til samskipta við „,regnhlífina” Krabbameinsfélagið. Voru niðurstöður pær að ánægja ríkir með samskipti og stuðning. Formannafundur var haldinn á Akureyri og nutum við gestrisni heimamanna. Fundað var í höfuðstöðvum KAON og rætt um ýmis innri mál. Velunnarakerfi Krabbameinsfélagsins kom til umræðu, skipulag pess og framkvæmd. Úr velunnarasjóði félagsins er nú veitt ár hvert styrkjum til skilgreindra verkefna aðildarfélaganna og parf að sækja um og rökstyðja beiðnir um styrkina. Nauðsynlegt er að aðildarfélögin fái upplýsingar um próun velunnarakerfisins og hvernig staðið er að pví.

Fjárhagsleg afkoma Krabbameinsfélagsins er pokkaleg, og með ráðdeild hefur verið unnt að auka starfsemina á ýmsum sviðum, svo sem í fræðslumálum. Fjáröflun hefur gengið vel og pað styrkir alla starfsemina. Reglur um meðferð fjár hjá Krabbameinsfélaginu er að finna á heimasíðu pess og par er líka skjal sem veitir margvíslegar upplýsingar um starfsemina, m.a. um fjármál, og var gefið út í október 2014. Skjalinu var dreift í 1.000 eintökum, m.a. til heilsugæslu og aðildarfélaga. Mæltist petta vel fyrir og verður væntanlega framhald á pessari upplýsingamiðlun.

Starfsárið hefur verið viðburðarríkt í sögu Krabbameinsfélagsins og verður m.a. minnst sem ársins pegar undirbúningur var hafinn að hópleit að ristilkrabbameinum, húsið í Skógarhlíð var endurnýjað og vísindasjóður var áfram undirbúinn og fjármagnaður, teknar voru upp HPV-mælingar og margt fleira. Lagður hefur verið góður grunnur að mörgum mikilvægum verkefnum og önnur próast vel á árinu. Allt er petta mögulegt vegna framlags íslensku pjóðarinnar til félagsins og pess trausts sem félagið nýtur. Meðan pess stuðnings nýtur getur Krabbameinsfélagið áfram verið pað afl til góðs sem Íslendingar vænta.

Ragnheiður Haraldsdóttir, forstjóri Krabbameinsfélags Íslands. 


\section{Stjórn og skipurit}

\section{Verndari Krabbameinsfélags Íslands:}

Vigdís Finnbogadóttir, fyrrverandi forseti Íslands

\section{Stjórn Krabbameinsfélags Íslands 2014-2015:}

\section{Aðalmenn:}

Jakob Jóhannsson læknir, formaður

Stefán Eiríksson lögreglustjóri, varaformaður

Sigurður P. Sigmundsson viðskiptafræðingur, gjaldkeri

Hulda Bjarnadóttir framkvæmdastjóri, ritari

Árni Einarsson uppeldisfræðingur, meðstjórnandi

Friðrik Vagn Guðjónsson, meðstjórnandi

Jón Porkelsson viðskiptafræðingur, meðstjórnandi

(kjörtímabil 2014-2016, fyrst kosinn 2008)

(kjörtímabil 2014-2016, fyrst kosinn 2010)

(kjörtímabil 2014-2016, fyrst kosinn 2009)

(kjörtímabil 2013-2015, fyrst kosin 2013)

(kjörtímabil 2014-2015, fyrst kosinn 2014)

(kjörtímabil 2013-2015, fyrst kosinn 2011)

(kjörtímabil 2014-2016, fyrst kosinn 2013)

\section{Varamenn:}

Hinrik Greipsson viðskiptafræðingur

Steinunn Eva Dórðardóttir sálfræðingur

(kjörtímabil 2014-2015, fyrst kosinn 2011)

(kjörtímabil 2014-2015, fyrst kosin 2012)

\section{Forstjóri:}

Ragnheiður Haraldsdóttir hjúkrunarfræðingur

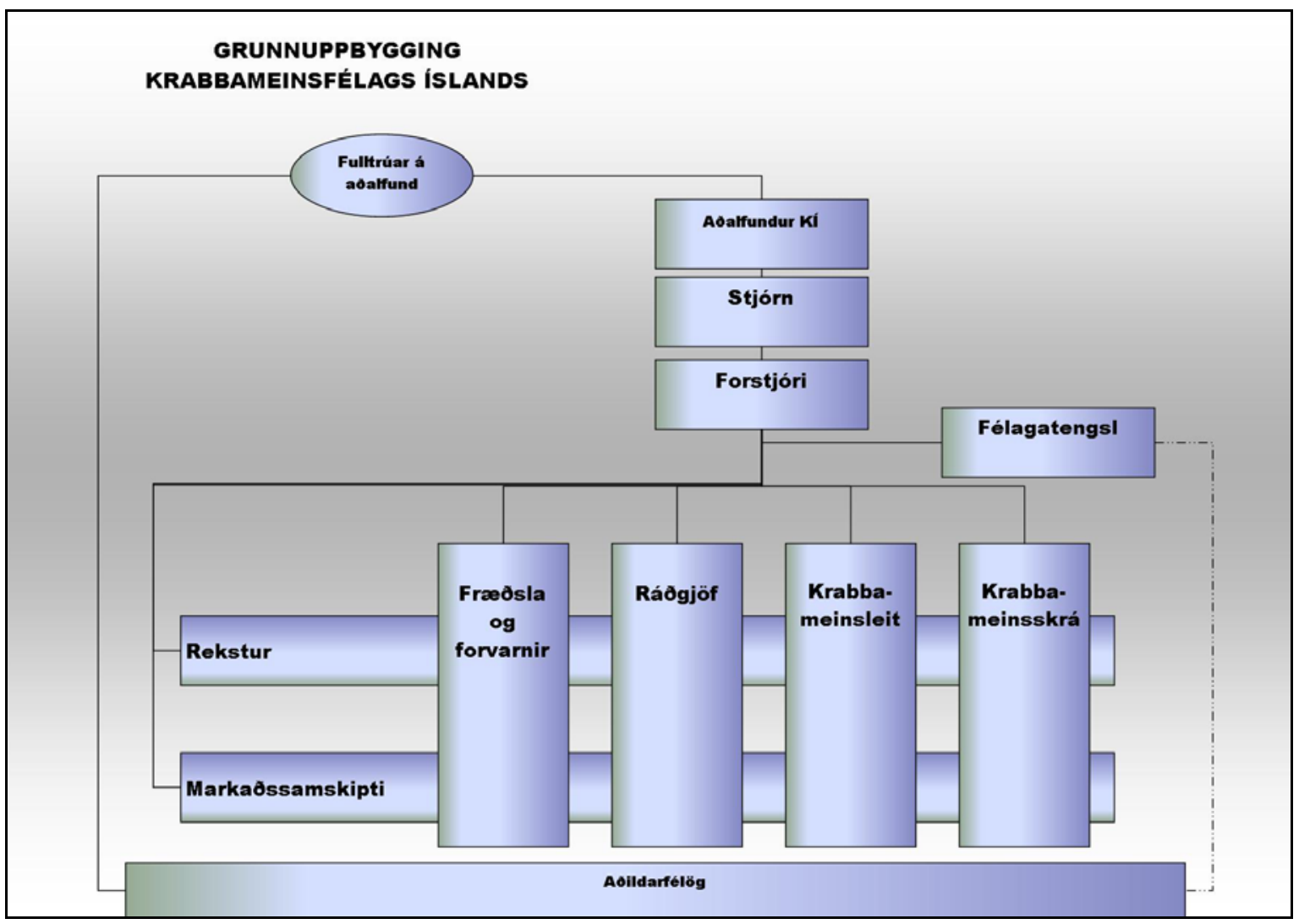




\section{Reikningar}

Frá Ernst \& Young ehf.

\section{Rekstrarreikningur 2014}

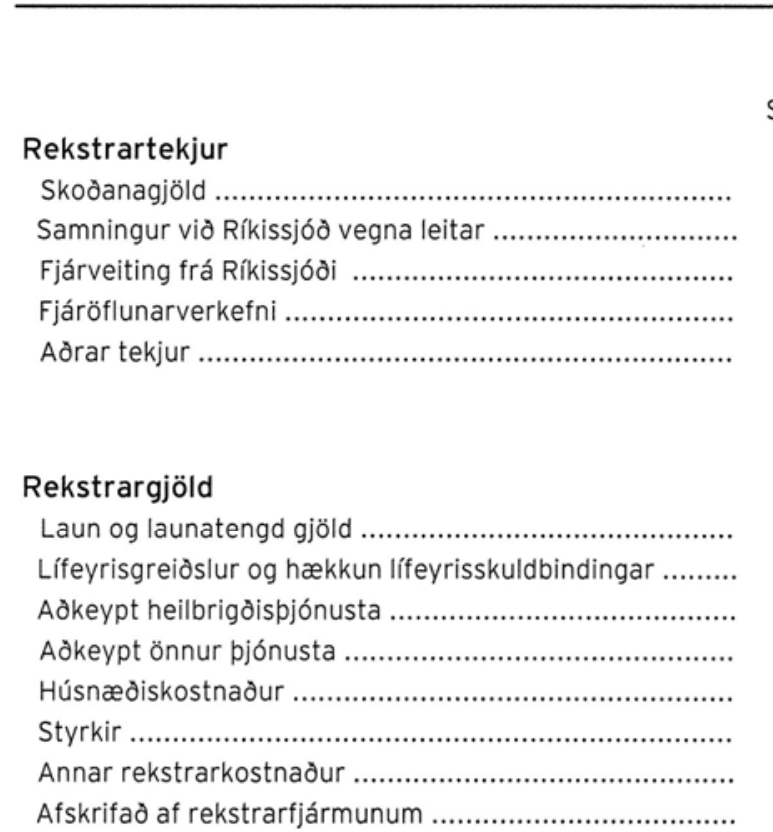

Afkoma án fjármunatekna og fjármagnsgjalda

\section{Fjármunatekjur og fjármagnsgjöld}

Vaxtatekjur, verðbætur og gengismunur

Vaxtagjöld, banka- og innheimtukostnaður
2014

2013

Skýr.

162.068.469

342.200 .000

27.700 .000

297.683 .882

39.542 .102

869.194 .453

\begin{tabular}{lr}
3 & 340.288 .127 \\
4 & 32.046 .208 \\
& 46.551 .357 \\
& 145.757 .660 \\
& 36.060 .989 \\
& 63.121 .222 \\
& 144.630 .783 \\
5 & 56.995 .076 \\
\hline 6 & 865.451 .422 \\
\hline
\end{tabular}

274.261 .504

58.443 .244

150.135 .218

115.948 .478

41.346 .864

49.947 .142

134.571 .761

32.144 .185

856.798 .396

3.743 .031

$(4.790 .781)$

\begin{tabular}{rrr}
16.017 .135 & & $\begin{array}{c}26.541 .714 \\
(681.401)\end{array}$ \\
\cline { 1 - 1 } & & $(1.125 .919)$ \\
\hline 15.335 .734 & & 25.415 .795 \\
\hline
\end{tabular}

Tekjuafgangur

19.078.765

20.625 .014 


\section{Efnahagsreikningur}

\section{Eignir}

Fastafjármunir

Skógarhlía 8

Raudarárstígur 33

Áhöld, tæki og annar búnaður

Fastafjármunir samtals

\section{Fjáreignir}

Verðbréf og aðrar eignir ífjárvörslu

Fjáreignir samtals

\section{Veltufjármunir}

Ýmsir skuldunautar og að̀rar eignir .............................. Handbært fé

Veltufjármunir samtals
2014

2013

Skýr.

\begin{tabular}{lrrr}
6 & 503.380 .698 & & 412.674 .434 \\
6 & 87.691 .122 & & 64.318 .153 \\
6 & 231.877 .032 & & 270.089 .183 \\
\cline { 2 - 3 } \cline { 3 - 4 } & 822.948 .852 & 747.081 .770 \\
\hline
\end{tabular}

7

\begin{tabular}{rr}
470.044 .530 & 459.238 .114 \\
\hline 470.044 .530 & 459.238 .114 \\
\hline
\end{tabular}

61.507 .833

50.264 .823

244.917 .718

224.527 .991

306.425 .551

274.792 .814 


\section{1. desember 2014}

Eigid fé og skuldir

Eigid fé

Skýr.

Eigið fé samtals

$9 \frac{590.937 .546}{590.937 .546} \frac{571.858 .781}{571.858 .781}$

Skuldbindingar og langtímalán

Langtímalán

10

4.318.953

4.432 .958

Reiknaðar lífeyrisskuldbindingar

11 735.810 .737

740.129 .690

731.414 .252

Skuldbindingar og langtímalán samtals

\section{Skammtímaskuldir}

ógreiddur kostnadur

150.378 .343

127.325.509

Næsta árs afborgun langtímalána

292.810

268.664

Adrar skammtímaskuldir

10

117.680 .544

45.812 .534

Skammtímaskuldir samtals

268.351 .697

173.406 .707

Skuldir samtals

1.008 .481 .387

909.253 .917 


\section{Sjóðstreymi 2014}

\begin{tabular}{|c|c|c|c|}
\hline & & 2014 & 2013 \\
\hline Handbært fé (til) frá rekstri & Skýr. & & \\
\hline 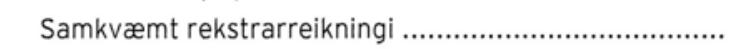 & & 19.078 .765 & 20.625 .014 \\
\hline \multicolumn{4}{|l|}{ Rekstrarliðir sem hafa ekki áhrif á fjárstreymi } \\
\hline 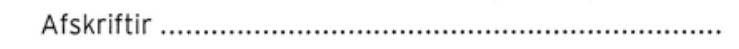 & 6 & 56.995 .076 & 32.144 .185 \\
\hline 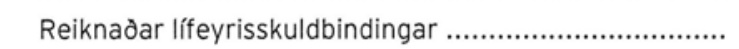 & 11 & 4.396 .485 & 33.318 .013 \\
\hline 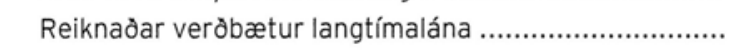 & & 196.755 & 496.285 \\
\hline 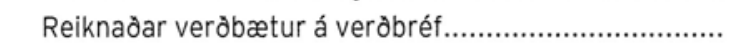 & 7 & $(10.806 .416)$ & $(21.875 .497)$ \\
\hline Hreint veltufé frá rekstri & & 69.860 .665 & 64.708 .000 \\
\hline \multicolumn{4}{|l|}{ Breytingar á rekstrartengdum eignum og skuldum } \\
\hline 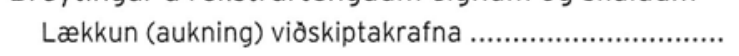 & & $(11.243 .010)$ & 3.981 .437 \\
\hline 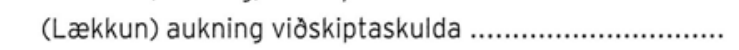 & & 94.920 .844 & 42.234 .345 \\
\hline Breytingar á rekstrartengdum eignum og skuldum & & 83.677 .834 & 46.215 .782 \\
\hline Handbært fé frá rekstri & & 153.538 .499 & 110.923 .782 \\
\hline \multicolumn{4}{|l|}{ Fjárfestingarhreyfingar } \\
\hline 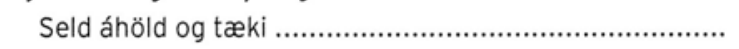 & 6 & 0 & 600.000 \\
\hline 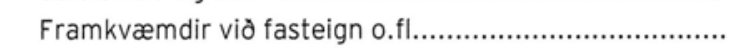 & 6 & $(132.862 .158)$ & $(24.634 .724)$ \\
\hline 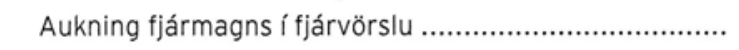 & 7 & 0 & $(48.000 .000)$ \\
\hline Fjárfestingarhreyfingar & & $(132.862 .158)$ & $(72.034 .724)$ \\
\hline \multicolumn{4}{|l|}{ Fjármögnunarhreyfingar } \\
\hline 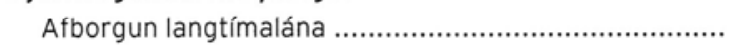 & & $(286.614)$ & $(272.120)$ \\
\hline Fjármögnunarhreyfingar & & $(286.614)$ & $(272.120)$ \\
\hline 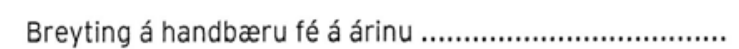 & & 20.389 .727 & 38.616 .938 \\
\hline 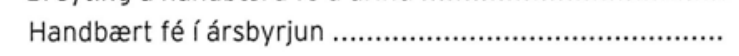 & & 224.527 .991 & 185.911 .053 \\
\hline Handbært fé í árslok & & 244.917 .718 & 224.527 .991 \\
\hline
\end{tabular}




\section{Skýringar}

\section{Upplýsingar um félagið}

Krabbameinsfélag Íslands er sjálfseignarstofnun og er tilgangur félagsins að̀ styðja og efla í hvívetna baráttuna gegn krabbameini. Lögheimili félagsins er að Skógarhlíd 8, 105 Reykjavík.

\section{Reikningsskilaaðferðir}

\section{Grundvöllur reikningsskilanna}

Ársreikningurinn er gerður í samræmi við lög um ársreikninga. Hann er í íslenskum krónum og byggir á kostnaðarverðsreikningsskilum. Hann er gerður eftir sömu reikningsskilaaðferðum og árið áður.

\section{Matsaðferðir}

Við gerð reikningsskilanna purfa stjórnendur að meta ýmis atriði sem tengjast ársreikningnum. Matsaðferðirnar eiga sér stoð í góðri reikningsskilavenju. Raunveruleg verðmæti peirra liða sem pannig eru metnir geta, við sölu eða aðra ráðstöfun, reynst önnur en samkvæmt matinu.

\section{Gengismunur}

Færslur í erlendum gjaldmiðlum eru í upphafi færðar á gengi viðskiptadagsins. Peningalegar eignir og skuldir í erlendum gjaldmiðlum eru umreiknaðar í íslenskar krónur á síðasta skráda gengi í árslok. Gengismunur sem myndast vegna pessa er færður í rekstrarreikning. Eignir og skuldir, adrar en peningalegar, sem færðar eru á kostnaðarverði eru umreiknaðar í íslenskar krónur á gengi viðskiptadagsins. Eignir og skuldir, aðrar en peningalegar, sem eru færðar á gangvirði eru umreiknaðar i íslenskar krónur á gengi pess dags sem gangvirði var ákvarðað.

\section{Verðbætur}

Verðtryggðar eignir og skuldir eru færðar miðað við vísitölur sem tóku gildi 1. janúar 2015. Verðbætur eru færðar í rekstrarreikning.

\section{Varanlegir rekstrarfjármunir}

Varanlegir rekstrarfjármunir eru færðir til eignar á kostnaðarverði eða endurmetnu stofnverði að̊ frádregnum afskriftum og virðisrýrnun ef hún er til staðar. Endurbætur eru eignfærðar ef líklegt er að pær skili félaginu framtíðarhagnaði og hægt er að meta kostnaðinn á áreiðanlegan hátt. Allur viðhaldskostnaður er gjaldfærður í rekstrarreikning pegar til hans er stofnað.

Afskriftir eru miðaðar við áætlaðan nýtingartíma einstakra varanlegra rekstrarfjármuna og reiknaðar sem fastur árlegur hundraðshluti af stofnverði, að̀ frádregnu áætluðu hrakvirði, miðað̃ viò eignarhaldstíma á árinu. Hrakvirði, nýtingartími og afskriftaraðferðir eru endurskoðaðar við lok hvers reikningsárs. Nánar er getið um afskriftir í skýringu nr. 6. 


\begin{abstract}
Verðbréf og ađrar eignir í fjárvörslu
Verðbréf og aðrar eignir í fjárvörslu eru upphaflega metnar á gangvirði eða kostnaðarverði að viðbættum viðskiptakostnaði. Mat á gangvirði miðast við síðasta skráða kaupgengi á reikningsskiladegi pegar til er virkur markaður með viðkomandi eign. Markaður telst virkur ef hægt er að̊ nálgast opinbert verð frá kauphöll eða öđrum aðilum og verðið endurspeglar raunveruleg og regluleg markaðsviðskipti á milli ótengdra aðila. pegar virkur markaður er ekki til staðar er gangvirði viðkomandi fjárfestingar reiknað út meda almennum viðurkenndum matslíkönum.
\end{abstract}

\title{
Viðskiptakröfur
}

Viðskiptakröfur eru færðar samkvæmt upphaflegu viðskiptaverði að teknu tilliti til gengisbreytinga og að frádreginni niðurfærslu sem gerð er til að mæta peim kröfum sem kunna að tapast. Niðurfærslan er byggð á mati á tapsáhættu gagnvart einstökum kröfum og kröfunum í heild. Kröfur sem eru endanlega tapaðar eru færðar út úr bókum félagsins.

\section{Handbært fé}

Til handbærs fjár teljast sjóður og bankainnstæður ađrar en pær sem eru hluti af fjárvörslusamningum.

\section{Tekjur}

Tekjur eru færðar pegar verulegar líkur eru á ad fjárhagslegur ávinningur peirra renni til félagsins og pegar hægt er að meta pær með áreiðanlegum hætti. Tekjur eru metnar á gangvirði móttekins endurgjalds að frádregnum afsláttum og sköttum.

Vaxtatekjur eru færðar í rekstrarreikning pegar pær falla til.

\section{Laun og launatengd gjöld}

\begin{tabular}{|c|c|c|}
\hline & 2014 & 2013 \\
\hline Laun & 274.495 .828 & 228.195 .204 \\
\hline \multirow{2}{*}{ 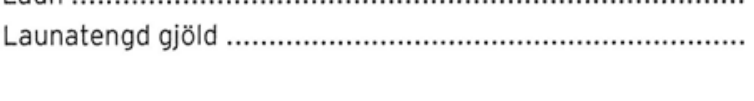 } & 65.792 .299 & 46.066 .300 \\
\hline & 340.288 .127 & 274.261 .504 \\
\hline
\end{tabular}

í árslok voru starfsmenn félagsins 58 i 46 stöðugildum, samanborid við 54 starfsmenn í 40 stöðugildum árið ádur. Laun stjórnenda námu um 65,2 milljónum króna á árinu, en um 69,7 milljónum króna árið ádur. Stjórn félagsins piggur ekki laun fyrir sín störf.

\section{Lífeyrisgreiðslur og hækkun lífeyrisskuldbindingar}

\begin{tabular}{|c|c|c|}
\hline & 2014 & 2013 \\
\hline 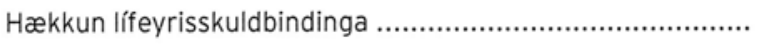 & 4.396 .485 & 33.318 .013 \\
\hline \multirow[t]{2}{*}{ 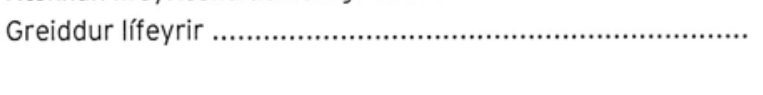 } & 27.649 .723 & 25.125 .231 \\
\hline & 32.046 .208 & 58.443 .244 \\
\hline
\end{tabular}

Lífeyrisskuldbinding félagsins er færð sem 55,5 - 59,6\% af fullum réttindum. Nánar er gerð grein fyrir skuldbindingu félagsins í skýringu nr. 11. 
5. Annar rekstrarkostnadur

\begin{tabular}{|c|c|c|}
\hline & 2014 & 2013 \\
\hline Rekstur áhalda og tækja ...................................................... & 47.025 .853 & 35.819 .687 \\
\hline 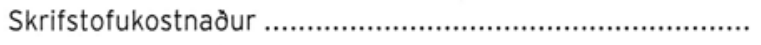 & 27.536 .085 & 25.860 .482 \\
\hline Stjórnun og umsýsla ..................................................... & 24.640 .163 & 41.001 .688 \\
\hline 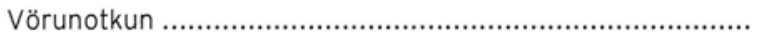 & 23.556 .604 & 23.453 .253 \\
\hline \multirow[t]{2}{*}{ 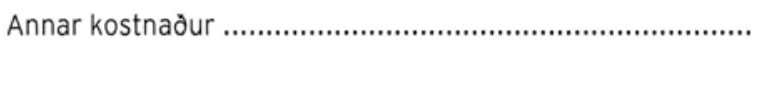 } & 21.872 .078 & 8.436 .651 \\
\hline & 144.630 .783 & 134.571 .761 \\
\hline
\end{tabular}

6. Varanlegir rekstarfjármunir

\begin{tabular}{|c|c|c|c|}
\hline & Skógarhlíd 8 & $\begin{array}{l}\text { Rauðarár- } \\
\text { stígur } 33\end{array}$ & $\begin{array}{l}\text { Áhöld tæki og } \\
\text { annar búnadur }\end{array}$ \\
\hline Heildarverð í ársbyrjun .............................. & 605.861 .665 & 73.221 .713 & 438.858 .874 \\
\hline 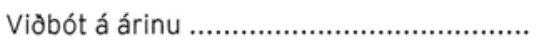 & 108.022 .158 & 24.840 .000 & 0 \\
\hline 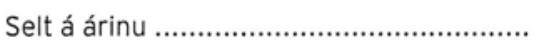 & 0 & 0 & 0 \\
\hline Heildarverð íárslok ................................ & 713.883 .823 & 98.061 .713 & 438.858 .874 \\
\hline 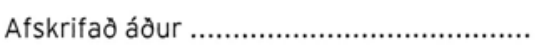 & 193.187 .231 & 8.903 .560 & 168.769 .691 \\
\hline 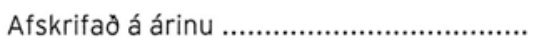 & 17.315 .894 & 1.467 .031 & 38.212 .151 \\
\hline 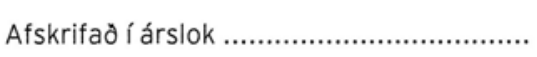 & 210.503 .125 & 10.370 .591 & 206.981 .842 \\
\hline Bókfært verð íárslok ............................ & 503.380 .698 & 87.691 .122 & 231.877 .032 \\
\hline Fyrningahlutföll ..................................... & $2,0 \%$ & $2,0 \%$ & $10-15 \%$ \\
\hline
\end{tabular}

Fasteignir félagsins eru metnar með eftirgreindum hætti. Til samanburðar er bókfært verð eignanna.

\begin{tabular}{|c|c|c|c|}
\hline & Fasteignamat & $\begin{array}{c}\text { Vátrygginga- } \\
\text { verðmæti }\end{array}$ & Bókfært verð \\
\hline 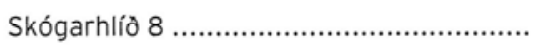 & 424.745 .000 & 552.755 .000 & 503.380 .698 \\
\hline \multirow{2}{*}{ Rauðarárstígur 33, 6 íbúdir ........................ } & 117.300 .000 & 93.880 .000 & 87.691 .122 \\
\hline & 542.045 .000 & 646.635 .000 & 591.071 .820 \\
\hline
\end{tabular}

\section{Verðbréf og aðrar eignir í fjárvörslu}

Fjáreignir Krabbameinsfélags Íslands samanstanda af bankareikningum, verðbréfum og öðrum eignum ífjárvörslu sem bókfærðar eru við markaðsverði íárslok.

\begin{tabular}{|c|c|c|}
\hline & 2014 & 2013 \\
\hline 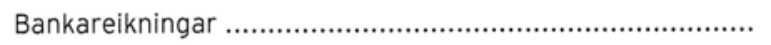 & 27.655 .468 & 15.338 .015 \\
\hline 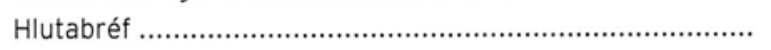 & 13.209 .586 & 12.266 .014 \\
\hline 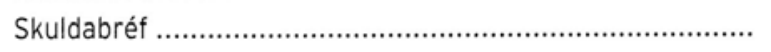 & 112.954 .595 & 107.156 .678 \\
\hline \multirow[t]{2}{*}{ 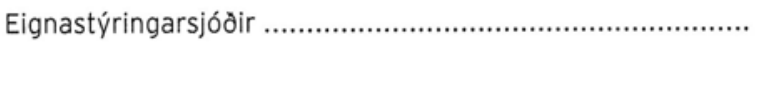 } & 316.224 .881 & 324.477 .407 \\
\hline & 470.044 .530 & 459.238 .114 \\
\hline
\end{tabular}




\section{Skýringar}

Breyting verðbréfaeignar og eigna í fjárvörslu greinist pannig:

Verðbréf og adrar eignir i fjárvörslu fársbyrjun

\begin{tabular}{|c|c|}
\hline 2014 & 2013 \\
\hline 459.238 .114 & 389.362 .617 \\
\hline 0 & 48.000 .000 \\
\hline 10.806 .416 & 21.875 .497 \\
\hline 470.044 .530 & 459.238 .114 \\
\hline
\end{tabular}

8. Veltufjármunir

Ýmsir skuldunautar

Kröfur á skuldunauta eru færðar við nafnverði að teknu tilliti til óbeinnar niðurfærslu. Óbein niðurfærsla krafna nemur kr. 485.000 íárslok.

9. Eigid fé

Órádstafad eigið fé

órádstafad frá fyrra ári

$\begin{array}{r}2014 \\ \hline 571.858 .781 \\ 0 \\ 19.078 .765 \\ \hline 590.937 .546 \\ \hline \hline\end{array}$

2013

Leidrétting vegna lífeyrisskuldbindinga

548.556 .720

Hagnaður ársins

2.677.047

20.625 .014

571.858 .781

\section{Langtímaskuldir}

Verðtryggà lán

4.611 .763

Næsta árs afborgun

(292.810)

4.318 .953

Afborganir langtímaskulda greinast pannig á næstu ár:

Afborganir 2015

292.810

Afborganir 2016

292.810

Afborganir 2017

292.810

Afborganir 2018

292.810

Afborganir 2019

292.810

Afborganir sídar

3.147 .713

4.611 .763

Langtímaskuld félagsins er lán frá íbúđarlánasjódi, með veði í fasteign félagsins að̀ Rauðarárstíg 33. Lánið ber $4,9 \%$ vexti. 


\section{Skýringar}

\section{Lífeyrisskuldbindingar}

Tryggingastærðfræðingur reiknaði út lífeyrisskuldbindingar félagsins miðað við árslok 2014. Miðað er vid 2\% reiknivexti og nýjar lífslíkur, byggdar á reynslu áranna 2007 - 2011. Útreikningurinn gerir rád fyrir ad 55,5\% af áfallinni skuldbindingu vegna LSR B-deildar falli á félagio og 59,6\% af áfallinni skuldbindingu vegna LH falli á félagið. Miðad er við $2 \%$ vexti og skiptast lífeyrisskuldbindingar pannig í árslok.

\begin{tabular}{|c|c|c|}
\hline & 2014 & 2013 \\
\hline Vegna ellilífeyris ...................... & 655.239 .462 & 639.329 .198 \\
\hline 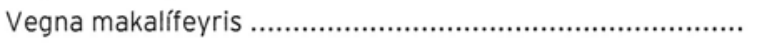 & 69.386 .952 & 80.309 .285 \\
\hline \multirow[t]{2}{*}{ 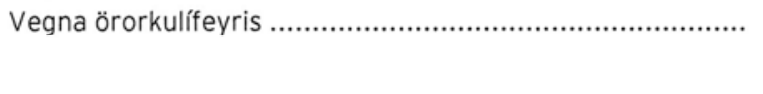 } & 11.184 .323 & 11.775 .769 \\
\hline & 735.810 .737 & 731.414 .252 \\
\hline 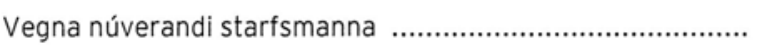 & 130.238 .500 & 146.648 .558 \\
\hline 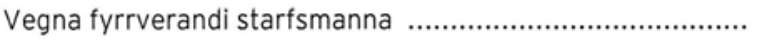 & 212.134 .235 & 212.475 .840 \\
\hline \multirow[t]{2}{*}{ 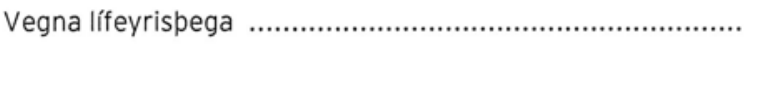 } & 393.438 .002 & 372.289 .854 \\
\hline & 735.810 .737 & 731.414 .252 \\
\hline
\end{tabular}

Tryggingastærðfræðingur tekur fram að útreikningur pessi byggir á forsendum, sem eru um margt hádar óvissu og pess vegna er niðurstaðan einnig óvissu bundin.

Rétt er ad taka fram ad pessi framsetning, p.e. ad færa lífeyrisskuldbindingarnar $\mathrm{i}$ ársreikning félagsins, felur ekki á neinn hátt í sér viðurkenningu á pví að skuldbindingarnar tilheyri félaginu, en að áliti stjórnenda félagsins tilheyra skuldbindingarnar íslenska ríkinu, en ekki félaginu.

Á undanförnum árum hafa stjórnendur félagsins rætt pessi sjónarmið sín við forsvarsmenn íslenska ríkisins, með pað fyrir augum að íslenska ríkið taki með formlegum hætti skuldbindingarnar yfir. ' l ljósi pess að félaginu hefur enn ekki orðið nægjanlega ágengt í við̀ræðum sínum við opinbera aðila, eru skuldbindingarnar færðar íársreikninginn.

Lífeyrisskuldbindingar skiptast pannig á deildir félagsins íárslok.

\begin{tabular}{|c|c|c|}
\hline & 2014 & 2013 \\
\hline 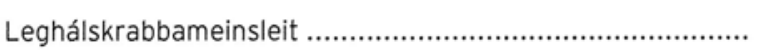 & 194.633 .174 & 198.355 .409 \\
\hline 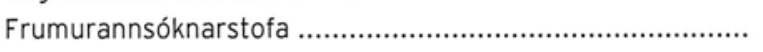 & 151.442 .523 & 145.568 .841 \\
\hline 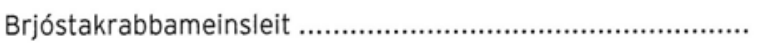 & 59.418 .419 & 58.103 .956 \\
\hline 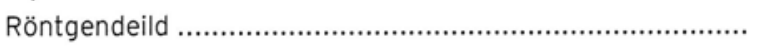 & 41.484 .071 & 39.198 .705 \\
\hline 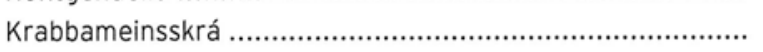 & 36.678 .974 & 35.203 .100 \\
\hline 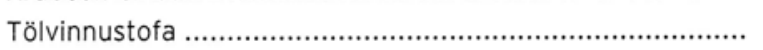 & 26.232 .819 & 24.189.134 \\
\hline 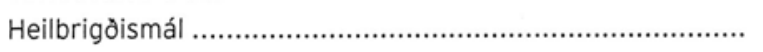 & 33.314 .480 & 31.320 .031 \\
\hline Skrifstofa og stjórnun & 76.510 .939 & 90.677 .485 \\
\hline 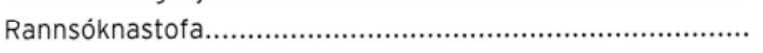 & 69.729 .961 & 66.172 .488 \\
\hline 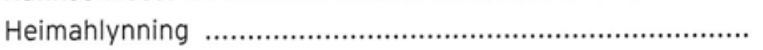 & 27.302 .382 & 25.588 .630 \\
\hline 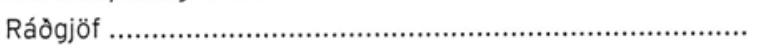 & 444.912 & 403.175 \\
\hline \multirow[t]{2}{*}{ 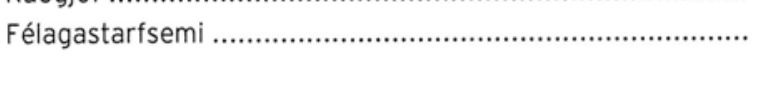 } & 18.618 .083 & 16.633 .298 \\
\hline & 735.810 .737 & 731.414 .252 \\
\hline
\end{tabular}


Breyting lífeyrisskuldbindinga á árinu greinist pannig á deildir

\begin{tabular}{|c|c|c|}
\hline & 2014 & 2013 \\
\hline Leghálskrabbameinsleit .......................... & $(3.722 .235)$ & 9.690 .924 \\
\hline 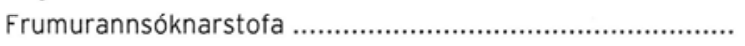 & 5.873 .682 & 7.427 .747 \\
\hline 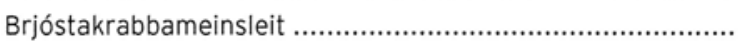 & 1.314 .463 & 2.620 .779 \\
\hline 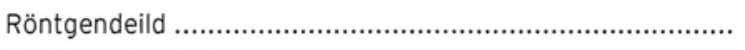 & 2.285 .366 & 1.601 .842 \\
\hline Krabbameinsskrá ...................... & 1.475 .874 & 1.948 .972 \\
\hline Tölvinnustofa ............................ & 2.043 .685 & 2.705 .397 \\
\hline Heilbrigðismál .......................... & 1.994 .449 & 1.406 .229 \\
\hline 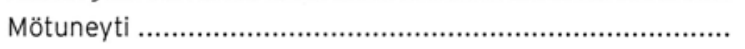 & 0 & $(4.079 .430)$ \\
\hline Skrifstofa og stjórnun & $(14.166 .546)$ & 2.633 .889 \\
\hline 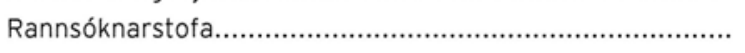 & 3.557 .473 & 4.852 .117 \\
\hline Heimahlynning & 1.713 .752 & 1.438 .304 \\
\hline 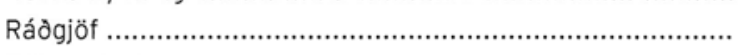 & 41.737 & 29.411 \\
\hline 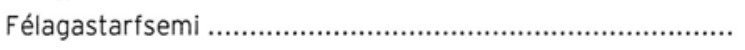 & 1.984 .785 & 1.041 .832 \\
\hline \multirow[t]{2}{*}{ 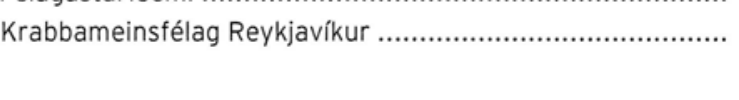 } & 0 & $(2.677 .047)$ \\
\hline & 4.396 .485 & 30.640 .966 \\
\hline
\end{tabular}




\section{Rekstrarsvið}

Í árslok 2014 störfuðu sjö starfsmenn á rekstrarsviði Krabbameinsfélags Íslands. Undir sviðið heyra skrifstofa, tölvudeild og mötuneyti.

Skrifstofa. Á skrifstofu starfa fimm starfsmenn. Meginverkefni skrifstofu eru fjármálastjórn, starfsmannastjórn, launavinnsla, innheimta, bókun reikninga, greiðsla reikninga, móttaka, símavarsla og umsjón með minningakortum ásamt ýmsum sérverkefnum og samningamálum.

Mötuneyti. Matráður félagsins hefur umsjón með mötuneyti félagsins og sér um veitingar fyrir fundi tengda starfsemi félagsins pegar pað á við.

Tölvudeild. Í tölvudeild starfar einn starfsmaður og er aðalviðfangsefni hans pjónusta við aðrar deildir félagsins á sviði vélbúnaðar og hugbúnaðar.

Dröstur Árni Gunnarsson. 


\section{Fræðsla og útgáfa}

Undir fræðslu- og útgáfusvið heyrir fræðsla, útgáfa, samskipti við aðildarfélög og fasteignin að Skógarhlíð 8.

Heilbrigðismál, tímarit Krabbameinsfélagsins, hefur komið út óreglulega undanfarin ár. Tímaritið er aðgengilegt á timarit.is allt frá 1949. Af öðrum útgáfuverkefnum má nefna ársskýrslu, sem gefin var út fyrir aðalfund og frágang ársskýrslu Leitarstöðvarinnar. Ritstjórn efnis á vefsíðu félagsins er eitt af verkefnunum.

Fræðslu- og fagráð Krabbameinsfélagsins hefur verið endurskipað og starfar í samvinnu Krabbameinsfélags Íslands, Krabbameinsfélags Reykjavíkur og Ráðgjafarbjónustunnar. Á fundum ráðsins hefur meðal annars verið unnið að stefnumótun.

Starfsmenn sviðsins unnu ýmis önnur störf á vegum Krabbameinsfélagsins. Pá hvíldi undirbúningur fyrir aðalfund Krabbameinsfélagsins vorið 2014 og formannafund um haustið að miklu leyti á pessari deild. Stuðningshópar sjúklinga voru aðstoðaðir á ýmsan hátt. Loks var sinnt öðrum verkefnum svo sem húsnæðismálum, undirbúningi fyrir árveknisátök o.fl.

Sviðsstjóri er ritari á fundum stjórnar félagsins, formaður húsnefndar og ritari rannsóknasjóða og velunnarasjóðs.

Jónas Ragnarsson. 


\section{Markaðsmál og fjáröflun}

Megintilgangur markaðssviðs er að efla starfsemi félagsins og kynningu á bví, styrkja ímynd pess og auka og efla fjáröflunarleiðir og par með tekjur félagsins. Undir markaðssvið fellur öll fjáröflun sem stunduð er undir vörumerki félagsins, að undanskildu Happdrætti Krabbameinsfélagsins. Markaðs- og fjáröflunarstjóri ber ábyrgð á ímynd og virði vörumerkjanna Krabbameinsfélagið, Bleika slaufan og Mottumars (Karlar og krabbamein). Markaðssvið sér um ýmis samskipti við fjölmiðla fyrir hönd Krabbameinsfélags Íslands, birgja er tengjast markaðs- og kynningarmálum, annast vefsíðu Krabbameinsfélagsins sem og samfélagsvefsíður pess og annast hverja pá markaðssetningu sem tengist félaginu.

Samtals eru tvö stöðugildi á sviðinu er annast markaðs- og fjáröflunarstarf félagsins, sem og kynningarstarf og heldur utan um pau ýmsu verkefni sem par fellur undir.

\section{Verkefni 2014}

Mottumars. Í mars 2014 fékk Krabbameinsfélag Íslands íslenska karlmenn til að safna yfirvaraskeggi og um leið að safna áheitum á vefnum www.mottumars.is. Yfirvaraskeggið er táknrænt og á að hvetja karlmenn til að tala um krabbamein og taka pátt. Detta var í sjöunda sinn sem átakið Karlar og krabbamein var framkvæmt en í fimmta sinn sem Mottumars var haldinn með pessu sniði. Meginmarkmið átaksins er að bæta pekkingu pjóðarinnar á krabbameini karla og auka árvekni, sem og að afla fjár sem gerir félaginu kleift að sinna forvörnum, fræðslu, ráðgjöf og rannsóknum á krabbameinum karla en framtíðarmarkmið er að fækka krabbameinum hjá karlmönnum. Gerðar voru nýjar auglýsingar til að ná til almennings. Farið var af stað með nýja herferð sem bar yfirskriftina „Hraustir menn“ og hún tengd við samnefnt lag í pýðingu Jakobs Jóhanns Smára. Karlakórar um allt land tóku pátt í að flytja lagið auk fjölda pekktra listamanna og alls tóku um 300 karlmenn, víðsvegar að af landinu, pátt í flutningnum. Herferðin gekk út á að hvetja alla karlmenn til að svara hreystikallinu og taka pátt í Mottumars - hvort sem pað var að heita á og pannig styrkja starf Krabbameinsfélagsins eða einfaldlega bara að vera meðvitaðir og mæta í reglulega krabbameinsskoðun. Með pví að fá karlakóra um allt land til leiks var ríkari áhersla lögð á að ná til karlmanna úti á landi en áður. Meginmarkhópur átaksins voru pó karlmenn á aldrinum 35-70 ára.

Miklar endurbætur voru gerðar á vefsíðu mottumars.is hvað varðar útlit og virkni allt með pað að markmiði að gera hann notendavænni og aðgengilegri fyrir pá sem vildu safna áheitum fyrir félagið og einnig pá sem sóttust eftir fræðslu. Átakið var opnað með svokölluðu „flash mob“ í Háskóla Íslands en par kom saman kvennakórinn Kötlurnar og söng lag átaksins „Hraustir menn“. Haldið var upp á mottudaginn, fyrirlestrar og ráðstefnur voru í Ráðgjafarpjónustunni og læknir var hjá Ráðgjafarpjónustunni sem heimsótti fyrirtæki með fyrirlestra um heilsu karla. Lögð var meiri áhersla en áður á notkun samfélagsmiðla til að koma skilaboðum á framfæri svo sem Facebook, Twitter, Instagram og Pinterest. Á Facebook bætti Mottumars við sig tæplega 2.000 nýjum fylgjendum og einnig fékk sjónvarpsauglýsing átaksins mikið áhorf með pátttöku almennings á samfélagsmiðlum og náði pannig til 42.000 manns. Fjöldi greina og frétta birtust um átakið og fékk pað einnig umfjöllun í ýmsum umræðupáttum. Slökkviliðsmenn dreifðu fræðslubæklingum á mottudaginn á fjölförnum stöðum en peir hafa alltaf verið duglegir að leggja átakinu lið.

Fjáröflunarátakið fór fram í formi áheitasöfnunar á mottumars.is en einnig var netkórinn kynntur til leiks en pað var ný leið til að safna áheitum og pannig gera fleirum að taka pátt. Par gat fólk flutt sína útgáfu af Hraustum mönnum og greiddi Arion banki svo upphæð til styrktar Krabbameinsfélaginu fyrir hvern flutning. Fjöldi fyrirtækja og einstaklinga studdi við átakið með sölu á ýmsum vörum og bjónustu og rann sá hluti af söluandvirði til Krabbameinsfélagsins.

Heilsuhlaup Krabbameinsfélagsins var haldið pann 5. júní. Eins og áður var boðið upp á 3 km og 10 km hlaup. Rúmlega 500 manns hlupu. Tími var mældur hjá öllum og úrslit voru birt á vefsíðu Krabbameinsfélagsins. Fjölmörg útdráttarverðlaun voru í boði og margir styrktaraðilar lögðu félaginu lið. Pollapönk sá um upphitun ásamta Helgu Camillu frá World Class og Pollapönk ræsti hlaupið við mikinn fögnuð viðstaddra. 
Bleika slaufan. Tilgangur Bleiku slaufunnar er að vekja athygli á krabbameinum hjá konum og er petta árvekni- og fjáröflunarátak. Að pessu sinni var aðaláherslan í árvekniátakinu að minna konur á mikilvægi pess að mæta í leghálskrabbameinsleit. Slaufan í síðasta átaki var hönnuð af Stefáni Boga Stefánssyni gullsmið hjá Metal design. Opnunin á bleiku slaufunni fór fram í Krabbameinsfélaginu par sem áhrifamikil auglýsing átaksins var frumsýnd en par var verið að leita eftir konum sem ekki höfðu skilað sér í leghálskrabbameinsleit. Einnig voru fyrstu slaufurnar afhentar og að pessu sinni voru pað tveir velunnarar Krabbameinsfélagsins og einn starfsmaður sem hengdu slaufur í einstaklinga sem greinst höfðu með krabbamein og höfðu nýtt sér pjónustu félagsins. Með pessari athöfn var lögð áhersla á hversu mikilvægur stuðningur velunnara Krabbameinsfélagsins er fyrir starfsemi félagsins. Mikil áhersla var lögð á fræðslu í átakinu og var heimasíðan bleikaslaufan.is sérstaklega sett upp með pað í huga. Miðum með myndum af týndum konum sem ekki höfðu skilað sér í leghálskrabbameinsleit ásamt fræðsluskilaboðum var dreift, peim komið fyrir á fjölförnum stöðum, á bílrúður og fleiri stöðum. Átakið fékk mikla umfjöllun í fjölmiðlum, greinar voru skrifaðar, viðtöl voru í blöðum og útvarpi og góð umfjöllun var um leghálskrabbameinsleit í sjónvarpi. Samfélagsmiðlar voru mikið notaðir og vinum bleiku slaufunnar fjölgaði um 1.500 manns. Mikið af bloggurum tóku pátt í átakinu og dreifðu fræðslu á sínum miðlum og hvöttu í leiðinni konur til að mæta í leit. Saga Garðarsdóttir fór með „gopro“ myndavél í leghálskrabbameinsleit og vakti pað mikla athygli. Mikil pátttaka var í bleika deginum og mikið af myndum voru sendar inn til Krabbameinfélagsins frá einstaklingum og fyrirtækjum sem héldu upp á daginn. Á Leitarstöðinni var opið hús og gátu konur mætt í leghálskrabbameinsleit án pess að eiga pantaðan tíma. Boðið var upp á bleikan drykk og ljúfa tónlist og var dagurinn í alla staði vel heppnaður. Átakið heppnaðist vel sem sýndi sig í mikilli fjölgun heimsókna í leitarstöðina í október og nóvember borið saman við september og einnig fjölgaði símtölum mikið til Krabbameinsfélagsins í október par sem fólk var að leita eftir upplýsingum um pjónustuna. Fjáröflunin gekk vel, salan á slaufunni var svipuð og fyrri ár og mikið af fyrirtækjum og einstaklingum lögðu verkefninu lið með annað hvort beinum styrkjum eða sölu á vörum og pjónustu par sem hluti ágóðans rann til Krabbameinsfélagsins. Meiri áhersla var lögð á netverslunina petta árið og var vöruúrval aukið til muna og má með sanni segja að peirri breytingu hafi verið vel tekið.

\section{Önnur verkefni}

Fjölmörgum öðrum verkefnum stórum sem smáum var sinnt á árinu. Lokið var við að endurhanna boðsbréf og annað kynningarefni tengt leitinni. Lögð var meiri áhersla á að fylgja eftir boðun á landsbyggðinni með pví að hvetja heilsugæslustöðvar og fjölmiðla á hverjum stað fyrir sig að taka pátt í að minna konur á mikilvægi pess að mæta í leghálskrabbameinsleit. Unnið var í velunnarakerfi félagsins og sett upp áætlun og henni hrint í framkvæmt til að tryggja að allt utanumhald og samskipti við velunnara félagsins væri faglegt og aðgengi að upplýsingum auðveldað. Unnið var að greiningarvinnu vegna nýrrar heimasíðu, vefstefna unnin og hafin var hönnun á nýrri síðu sem áætlað að er verði kláruð á árinu. Ýmis aðstoð við Ráðgjafarpjónustuna var veitt, m.a. var byrjað að framleiða nýtt kynningarefni fyrir deildina, stuðningur vegna „Kastað til bata“ og „Karlarnir og kúlurnar“ og ýmislegt annað. Reykjavíkurmarabon var haldið í ágúst bar sem fjölmargir hlupu til styrktar félaginu og var tækifærið nýtt til að koma fræðslu á framfæri. Einnig tók félagið pátt í Globeathon með Líf styrktarfélagi sem er albjóðlegt átak til að efla vitund, pekkingu og rannsóknir tengdar krabbameinum í kvenlíffærum. Lögð var lögð áhersla á að byggja upp vefverslun félagsins með breiðara vöruúrvali sem ein leið í fjáröflun og hefur pví verið vel tekið.

\section{pakkarorð}

Markaðs- og fjáröflunarsvið Krabbameinsfélags Íslands pakkar öllum peim einstaklingum, félögum, stofnunum og fyrirtækjum sem hafa lagt félaginu lið á árinu með fjárframlögum, vinnu og með annars konar stuðningi. pitt framlag skiptir máli.

Ólöf María Jóhannsdóttir. 
Ársskýrsla markaðs- og fjáröflunarstjóra hér að ofan miðast við áramót, en ekki aðalfundi eins og aðrar ritaðar greinargerðir í ársskýrslunni. Er petta m.a. vegna afleysinga í barnsburðarleyfi. Hér á eftir fer stutt samantekt um verkefni tengd markaðsmálum og fjáröflun fyrir fjóra fyrstu mánuði árið 2015.

Frá janúar til maí 2015 var haldið áfram peim verkefnum sem að framan er lýst. Lögð var áhersla á samskipti við velunnara mánaðarlega og mælist pað vel fyrir. Ætlunin er að auka pessi samskipti og leitast við að ná til fleiri velunnara með mánaðarlegum útsendingum en nú gefst kostur á. Ný heimasíða félagsins hefur verið í undirbúningi og mun hún verða opnuð fljótlega. Nýja heimasíðan mun tryggja einfaldari aðgang að fræðsluefni sem hefur verið stóraukið og bætt, en æ fleiri nota www.krabb.is til pess að afla sér upplýsinga um margvísleg efni tengd krabbameinum. Dá fær Ráðgjafarbjónusta Krabbameinsfélagsins aukið vægi á heimasíðunni í samræmi við aukna starfsemi. Samfélagsmiðlar hafa verið nýttir vel, pannig eru fésbókarsíðurnar Bleika slaufan og Mottumars vinsælar og mikið skoðaðar. Skráðar voru viðmiðunarreglur um samskipti við fyrirtæki sem veita starfsemi Krabbameinsfélagsins stuðning með styrkjum, en mikilvægt er að tryggja gagnsæi, samræmi og góða og trausta samskiptahætti. Markaðsstjóri Krabbameinsfélagsins gegnir mikilvægum störfum við alls kyns kynningar ekki síst á sviði fræðslumála. Framsetning fræðsluefnis og leiðir til að kynna efnið auka gildi hins faglega starfs við gerð fræðsluefnis, og nýstárleg nálgun m.a. í Mottumars getur vegið pungt.

Fyrir Mottumars 2015 var lögð mikil áhersla á að skerpa á fræðsluhlutanum. Mikið var sett inn á heimasíðu Krabbameinsfélagsins af nýju fræðsluefni, og skilgreint hverjar fræðsluparfir væru. Lögð var áhersla á krabbamein í ristli, en marsmánuður er einmitt tileinkaður ristilkrabbameinum víða um lönd. Mælingar sýndu svo að fólk sem fór inn á síðu átaksins leitaði eftir pessum upplýsingum, og gat skoðað pær og nýtt sér. Fjáröflun tengd pessu átaki byggir annars vegar á áheitasíðu og hins vegar á ýmsum öðrum leiðum. Fækkað hefur ár frá ári peim sem taka pátt á áheitasíðunni, en fjáröflun í heildina er svipuð og verið hefur undanfarin ár. Nokkrir einstakir keppendur á áheitasíðunni skiluð til Krabbameinsfélagins háum fjárhæðum og svo var einnig um nokkur fyrirtæki. bekkingarmiðlun og árvekni í mars var afar öflug. Myndband sem gert var til að vekja athygli á krabbameinum í ristli og höfða átti til karla var skoðað meira en 180.000 sinnum hér heima og erlendis. Aðsókn til lækna í kjölfarið var mjög mikil.

Fjáröflun á vegum Krabbameinsfélagsins fer fram eftir mörgum og margvíslegum leiðum. Einstaklingar leggja fram fjármagn m.a. með pví að kaupa söluvarning til styrktar félaginu, t.d.í gegnum netsöluna eða í verslun félagsins í Skógarhlíð, en alltaf taka sig líka til einstaklingar og hópar sem próa og selja nýstárlegan varning til styrktar starfseminni. Má t.d. nefna að einstaklingur prjónaði 110 pör af barnavettlingum sem hafa verið seldir í Skógarhlíðinni, en mörg svipuð dæmi mætti nefna. Margir Íslendingar eru velunnarar félagsins og greiða mánaðarlega upphæð. Fjölmargir hafa styrkt starfsemina með peim hætti í árafjölda. Gerðir voru samningar við fyrirtæki eða fenginn fjárhagsstuðningur peirra sem vegur pungt í allri starfsemi félagsins. pannig tryggði Líftryggingafélagið Okkar líf fjármagn til að hefja undirbúning fyrir hópleit að ristilkrabbameinum og vegna pess er unnt að ráða verkefnisstjóra og leggja faglega góðan grunn að hópleitinni. Samtök fyrirtækja í sjávarútvegi (SFS) lögðu fram fjármagn sem gerði Krabbameinsfélaginu kleift að vinna vandaða vinnu við árvekniátak og kynningar á Mottumars, en pannig var mögulegt að nýta pað fé sem safnast í mánuðinum beint í Mottumarsverkefni félagsins. Á vegum fyrirtækja innan vélbanda SFS vinna margir karlar og er pessi samningur til pess fallinn að ná betur til pess hóps og væntanlega að hafa áhrif til bættrar heilsu hans. Verslunarsamstæðan Bestseller studdi Ráðgjafarpjónustuna mjög veglega, en söluátak peirra í aprílbyrjun færði félaginu möguleika á að byggja upp net- og símasamskipti við pá sem leita til Ráðgjafarbjónustunnar. Verslunin Lindex færir okkur árlega fjármuni vegna Bleiku slaufunnar, og svo mætti áfram telja. Ekki gefst kostur á í stuttri samatekt að geta peirra fjölmörgu sem leggja málefnum félagsins lið, en allt kemur petta starfinu til góða, stórt og smátt. Hvetjum við alla til að fylgjast með störfum félagsins á vefsíðu pess og að notfæra sér pá bjónustu sem er í boði. Mikið af pjónustunni og verkefnum Krabbameinsfélagsins er ekki greidd af peim sem færa sér pjónustuna í nyt, heldur af peim sem leggja fram fjármagn með margvíslegum hætti. раð ber að pakka. 


\section{Ráðgjafarpjónusta Krabbameinsfélagsins}

Frá upphafi hefur Krabbameinsfélagið unnið að stuðningi við krabbameinsgreinda og aðstandendur peirra. bessi stuðningur hefur próast í takt við aukna pekkingu, breytingar í samfélaginu og parfir peirra sem nýta sér pjónustuna. Krabbameinsráðgjöfin hófst 1995 og má segja að hún hafi verið undanfari Ráðgjafarpjónustunnar. Við hana störfuðu hjúkrunarfræðingar í hlutastarfi og markmiðið var að auðvelda almenningi aðgang að upplýsingum og ráðgjöf varðandi krabbamein og stuðning par sem við átti. Ráðgjafarpjónustan hóf starfsemi sína fyrir rúmum sjö árum. Starfsmenn eru nú fjórir í 2,6 stöðugildum. Jafnframt vinnur framkvæmdastjóri Krafts, félags ungs fólks sem greinst hefur með krabbamein og aðstandenda peirra náið með starfsfólki Ráðgjafarpjónustunnar ásamt sálfræðingi Krafts sem hefur umsjón með stuðningsnetinu. Starfsmenn pjónustuskrifstofa svæðafélaga Krabbameinsfélagsins njóta faglegs stuðning Ráðgjafarpjónustunnar, sem og svæðafélög og stuðningshópar. Ípróttafræðingur, með sérmenntun í pjálfun krabbameinssjúklinga, hefur verið í tímabundnu verkefni í Ráðgjafarbjónustunni. Margir hafa komið að með námskeið, fyrirlestra og örráðstefnur á árinu.

\section{Starfsemin}

Hjá Ráðgjafarpjónustunni er veitt fjölbreytt bjónusta sem snýr að upplýsingagjöf, fræðslu, ráðgjöf og sálfélagslegum stuðningi eða endurhæfingu við pá sem hafa greinst með krabbamein og við aðstandendur peirra. Deir sem nýta sér pjónustuna eru á öllum stigum sjúkdómsins, peir geta verið í greiningarferlinu, nýgreindir, í meðferð og að endurgreinast. Einnig eru margir komnir töluvert frá meðferð og hafa jafnvel ekki náð að fóta sig aftur í lífinu, enn aðrir eru mjög veikir með útbreiddan sjúkdóm og glíma við mikil einkenni. Aðstandendur nýta sér einnig bjónustuna og síðast en ekki síst eftirlifendur, peir sem hafa misst náinn ættingja eða vin af völdum krabbameins.

Markmið pjónustunnar er að aðstoða fólk við að ná jafnvægi í lífinu eftir pær breyttu aðstæður sem greining krabbameins veldur. Einnig að koma að endurhæfingu fólks eftir greiningu krabbameins og auka pannig möguleika peirra til að komast aftur í vinnu eða til að verða virkari í lífinu á ný. bjónustan nær jafnt til einstaklinga sem hópa. Samskipti fara fram með viðtölum, símaráðgjöf og með tölvupósti.

Með pessum tölum má greina aukningu á fjölda samskipta. Einnig má sjá að fleiri nýta sér viðburði pjónustunnar sem flokka má niður í námskeið, fræðsluerindi, ráðstefnur, heilsuæfingar og jafningjastuðning hjá stuðningshópum félagsins.

Sem fyrr nær pjónustan jafnt til einstaklinga sem hópa og fólk getur komið án pess að gera boð á undan sér eða pantað tíma. bjónustan er í flestum tilfellum án endurgjalds. Í Ráðgjafarpjónustunni er góð aðstaða fyrir fólk til að hittast og deila upplifun sinni á veikindum. Máttur jafningjastuðningsins er mikill. Tíu stuðnings hópar eru með aðstöðu hjá Ráðgjafarpjónustunni og hafa flestir peirra reglulega fundi yfir vetrartímann.

\section{Djónusta 2012-2014.}

\begin{tabular}{lrrr} 
& 2012 & 2013 & 2014 \\
Samskipti við einstaklinga & 1.460 & 1.790 & 3.866 \\
- símtöl & & 897 & 1.043 \\
- tölvupóstur & & 322 & 2.344 \\
- viðtöl & & 571 & 479 \\
Fjöldi viðburða & 146 & 180 & 210 \\
Aðsókn á viðburði & 3.100 & 3.700 & 4.371 \\
& & & \\
\hline
\end{tabular}


Yngsti hópurinn er stuðningshópurinn Frískir menn, stofnaður í mars 2014. Í honum er menn sem greinst hafa með blöðruhálskirtilskrabbamein og hafa möguleika á að vera í virku eftirliti án annars inngrips.

Framkvæmdir vegna endurbóta á húsnæðinu hefur óneitanlega haft áhrif á starfsemina á árinu og bá helst haft pær afleiðingar að dregið hefur úr viðtölum og djúpslökun. Petta hefur samt gengið framar vonum og má pakka gott samstarf alla er komu að framkvæmdunum.

\section{Símaráðgjöfin}

Á síðasta ári var ákveðið að stytta opnun símaráðgjafarinnar í tvo tíma á dag frá kl. 13-15 virka daga. Hjúkrunarfræðingur eða félagsráðgjafi svarar símanum og svara einnig tölvupóstum sem berast til pjónustunnar. Í árveknimánuðunum var læknir einnig við símann. Opnað var nýtt netfang radgjof@krabb.is og gjaldfrjálsa númerið okkar er 8004040 og hægt er að leggja inn skilaboð á símsvara. Mikill vilji er fyrir pví að efla og bæta pessa pjónustu og gera hana meira í takt við sambærilegar pjónustur hjá krabbameinsfélögunum á Noðurlöndunum. betta erum við að sjá að muni takast á komandi mánuðum pví í síðasta mánuði stóð fyrirtækið Bestseller fyrir alpjóðlegum góðgerðardegi, fyrir öll vörumerki sín um allan heim. Krabbameinsfélaginu voru færðar 6,2 miljónir og mun allt pað fé verða nýtt til að efla og bæta símaráðgjöfina. Detta er ómetanlegur stuðningur í págu fólksins í landinu sem nú mun eiga auðveldara með að nýta sér símaráðgjöfina.

\section{Námskeið}

Fjölmörg námskeið hafa verið í boði á árinu. Fastir liðir í dagskrá pjónustunnar voru Qi-gong ástundun og heilsuæfingar, núvitund, HAM-námskeið (hugræn atferlismeðferð), snyrtinámskeið (Gott útlit - betri líðan) og stuðningur við ekkjur og ekkla sem hefur verið haldið í samstarfi við Nýja dögun samtök um sorg og sorgarviðbrögð. Önnur námskeið sem má nefna eru, sjálfseflingarnámskeið, fræðsla frá Landspítala um ýmsa pætti er snúa að veikindunum, námskeið í að skapa og skrifa, ásamt peirri nýjung að bjóða upp á spænskunámskeið. Á aðventunni voru rithöfundar fengnir til að lesa upp úr nýjum bókum.

Hádegisfyrirlestrar hafa verið annan hvern miðvikudag í hverjum mánuði yfir vetrartímann. Par er leitast við að hafa fræðslu um pau mál sem snúa að heilsu og betri líðan. Aukin áhersla var lögð á næringu og hreyfingu samhliða annarri fræðslu. Örráðstefnur og málping sem haldin voru á starfsárinu voru, í október og mars. Í október var haldið málping sem bar heitið, Er besta pjónusta í boði? Málping um heilbrigðispjónustu við krabbameinssjúklinga. Málpingið var með nýju sniði par sem stutt erindi voru flutt í upphafi en síðan boðið upp á pallborðs umræður. Í mars var haldin örráðstefna um Karla og Krabbamein krabbamein. Góð pátttaka var á pessa viðburði. Krabbameinsfélag Reykjavíkur stóð fyrir pessum viðburðum með Ráðgjafarbjónustunni ásamt peim stuðningshópum sem eru starfandi á peirra vegum. Einnig kom Krabbameinsfélag Hafnarfjarðar að málpinginu í október.

Ráðgjafarbjónustan stóð fyrir HAM-námskeiði á líknardeild Landspítalans á starfsárinu. Námskeið í Hugrænni atferlismeðferð (HAM) eru stöðugt í gangi í Ráðgjafarbjónustunni, pau hafa verið mjög vel nýtt og eru komin til að vera. Einnig var boðið upp á námskeiðið á Suðurnesjum í samstarfi við Krabbameinsfélagið par á vormánuðum. Núvitundarnámskeiðin eru stöðugt í gangi og ávallt full bókuð. Tvær nýjungar hafa verið í boði hjá Ráðgjafarpjónustunni. Um er að ræða námskeið um sogæðabjúg á handlegg sem byggir á fræðslu og æfingum. Námskeiðið er ætlað konum sem greinst hafa með brjóstakrabbamein. Tveir sjúkrabjálfarar halda utan um framkvæmd námskeiðsins og má segja að mikil ánægja er með petta framtak. Annað námskeið sem einnig er nýtt er hugræn atferlismeðferð við svefnvanda. Fjölmargir krabbameinssjúklingar og einnig aðstandendur peirra eiga við svefnörðuleika að stríða og pví löngu tímabært að bjóða upp á slíkt námskeið. Sálfræðingur með mikla reynslu í pessum fræðum heldur námskeiðin og lögð er áhersla á að mæta hverjum og einum par sem hann er staddur.

Frá pví á haustmánuðum hefur Ráðgjafarpjónustan í samstarfi við 8 samtök og stofnanir, staðið að undirbúningi að stórri ráðstefnu á undir yfirskriftinni „Listin að deyja“ en tilgangur hennar er að fá fólkið í samfélaginu til að ræða opið um dauðann. Ráðstefnan var haldin í Hátíðarsal Háskóla Íslands pann 16. apríl sl. bað er skemmst frá pví að segja að viðtökur fóru fram úr björtustu vonum og met sprengt í aðsókn. 
Rúmlega 400 manns sóttu ráðstefnuna sem annars vegar fór fram með framsögu fræðimanna og leikmanna og hins vegar með pallborðsumræðum. Fyrirhuguð er frekari samvinna pessara aðila um málefnið.

Framhald er á fræðslu fyrir heilbrigðisstarfsfólk er orðinn fastur páttur í pjónustunni sem próaður verðu áfram. Í boði voru tvö tjáskiptanámskeið „Að færa slæmar fréttir“ og voru pau vel sótt af læknum og hjúkrunarfræðingum. Fyrirhugað er að halda áfram að bjóða upp á petta og komið er á samstarf við EC4H (Effective comunication for Helthcare) í Skotlandi með pessi námskeið. Einnig var starfsfólki krabbameinseiningar Landspítalans boðið upp á fjölbreytt námskeið í slökun par sem kynntar voru ólíkar leiðir í slökun. Ráðgjafarbjónustan studdi við og tók pátt í undirbúning á málpingi sem haldið var í nóvember hjá fagdeild krabbameinshjúkrunarfræðinga.

\section{Samstarfsaðilar}

Mikið samstarf er við stuðningshópa félagsins og daglega erum við minnt á hversu jafningjastuðningurinn er mikilvægur í bland við faglega stuðninginn. Ráðgjafarpjónustan er faglegt bakland fyrir pjónustuskrifstofurnar sem eru átta á landsbyggðinni. Samráðsfundir eru haldnir tvisvar á ári, par er rætt um samstafið og hvernig við getum deilt og lært af hvort öðru. Einnig hefur verið boðið upp á fræðslu um pau mál sem eru í gangi. Dæmi um fræðslu sem tekin var fyrir á starfsárinu var máttur tómstunda í veikindum, hvað er handleiðsla, Qi-gong og ólíka áherslur kynntar innan pess og einnig var stuðningsnet Krafts kynnt. Boðið var аð koma með pessa fræðslu út á landsbyggðina og voru nokkrar bjónustuskrifstofur sem páðu pað. Áfram var áhersla lögð á að bæta skráningu á samskiptum á pjónustuskrifstofunum. Á formannafundi sem haldinn var á Akureyri í september kynnti Atli Már Sveinsson skýrslu sína um endurhæfingarmál krabbameinssjúklinga sem hann vann á árinu fyrir Krabbameinsfélagið. Á sama fundi kynnti Gunnjóna Una Guðmundsdóttir félagsráðgjafi handbók um réttindi krabbameinssjúklinga sem hún hefur tekið saman og uppfærir eftir pörfum.

Mikilvægt samstarf er við heilbrigðisstarfsfólk Landspítala sem sinnir krabbameinssjúklingum og aðstandendum peirra. Starfsfólk spítalans er ötult við að bjóða upp á fræðslu hjá Ráðgjafarbjónustunni og hefur samvinna verið m.a. við endurhæfingarteymi Landspítala um námskeiðslotur fyrir nýgreinda krabbameinssjúklinga. Samstarf við fagfólk spítalans er okkur ómetanleg og gerir okkur kleift að koma betur til móts við krabbameinsgreinda og aðstandendur peirra.

Ráðgjafarpjónustan kom að stóru árvekniverkefnum félagsins í mars og október, Mottumars og Bleiku slaufunni. Starfsmenn tóku pátt í undirbúningi, skipulagningu á fræðslu til fyrirtækja og skóla ásamt pví að koma fram í fjölmiðlum.

\section{Verkefni}

Starfsmenn hafa farið víða með kynningar á pjónustunni má par helst nefna á Landspítala á peim deildum sem eru að veita krabbameinsmeðferð. Starfsmenn voru með erindi á norrænni ráðstefnu sem haldin var í Reykjavík á vegum Stóma samtakanna í september.

Verkefni sem hafa verið í gangi og eru komin til að vera eru „Kastað til bata“ sem unnið er í samvinnu við Stuðningshópinn Brjóstheill - Samhjálp kvenna og „Karlarnir og kúlurnar“ sem er í samstarfi við Kraft, Góða hálsa og Fríska menn. Hagnýtar upplýsingar voru endurskoðaðar og nýr bæklingur kom út um starfsemi Ráðgjafarbjónustunnar.

Nýtt verkefni fór í gang í janúar í samstarfi við Kraft stuðningsfélag fyrir ungt fólk með krabbamein og aðstandendur peirra. Verkefnið ber heitið Fítonskraftur og er tilraunarverkefni til hálfs árs. Stofnaður var endurhæfingarhópur sem stuðlar að útivist og hreyfingu fyrir fólk á aldrinum 18 til 40 ára og hefur greinst með krabbamein. Umsjón með verkefninu hefur Atli Már Sveinsson ípróttafræðingur með sérhæfingu í pjálfun krabbameinsgreindra. Óhætt er að segja að petta sé skemmtileg nýjung og áhugaverð nálgun í endurhæfingu ungs fólks með krabbamein.

Bæklingur um Ráðgjafarpjónustuna var endurnýjaður á haustmánuðum og í mars kom síðan út bæklingur um starf stuðningshópa félagsins. Facebook-síða Ráðgjafarpjónustunnar var opnuð í mars 2015. 
Nýtt fræðslu- og fagráð var stofnað á árinu. Að pví koma Krabbameinsfélag Ísland og Krabbameinsfélag Reykjavíkur. Formaður ráðsins er Lára G. Sigurðardóttir læknir. Forstöðumaður Ráðgjafarbjónustunnar á sæti í ráðinu en pví er ætlað að marka stefnu í fræðslumálum félagsins og fræðsluverkefnum komandi árs.

Nemar úr félagsvísindadeild Háskóla Íslands hafa verið í verknámi í Ráđgjafarbjónustunni sem áđur og er petta mikilvægur páttur hjá pjónustunni.

Starfsmenn sóttu sér endurmenntun, hjúkrunarfræðingur fór á dáleiðslunámskeið og einnig fóru tveir starfsmenn á ráðstefnu í Kaupmannahöfn European Cancer Rehabilitation and Survivorship. bessi ráðstefna er mikilvæg til að geta fylgst með nýjungum í endurhæfingarmálum krabbameinsgreindra. Félagsráðgjafi sótti fund í Brussel á vegum European Cancer Leagues, (ECL) og forstöðumaður er kominn í vinnuhóp á vegum, ECL, Patient support working goup (PSWG). Tveir fundir voru á árinu og kom í hlut forstöðumanns að hafa par erindi. Pau mál sem voru í brennidepli á starfsárinu hjá hópnum eru, endurhæfing krabbameinssjúklinga, réttinda- og tryggingamál og líknarmeðfeð.

\section{Gjafir og styrkir}

Ráðgjafarbjónustunni bárust ýmsar gjafir og peningastyrkir á árinu. Má par nefna m.a. styrkur að upphæð 600.000 kr frá Sorpu (jólastyrkveiting) sem gerði okkur kleift að byrja með námskeiðin um hvað hægt er að gera við svefnvanda. Soroptimistaklúbbur Reykjavíkur veitti styrk fyrir núvitundarnámskeið fyrir ekkjur að upphæð 360.000. kr. og eins og áður var getið styrkurinn frá Bestsellers að upphæð 6,2 milljón króna. Pessar gjafir og styrkir hefa verið ómetanlegar til að geta eflt pjónustu við krabbameinssjúklinga og aðstandendur peirra enn frekar.

Sigrún Lillie Magnúsdóttir.
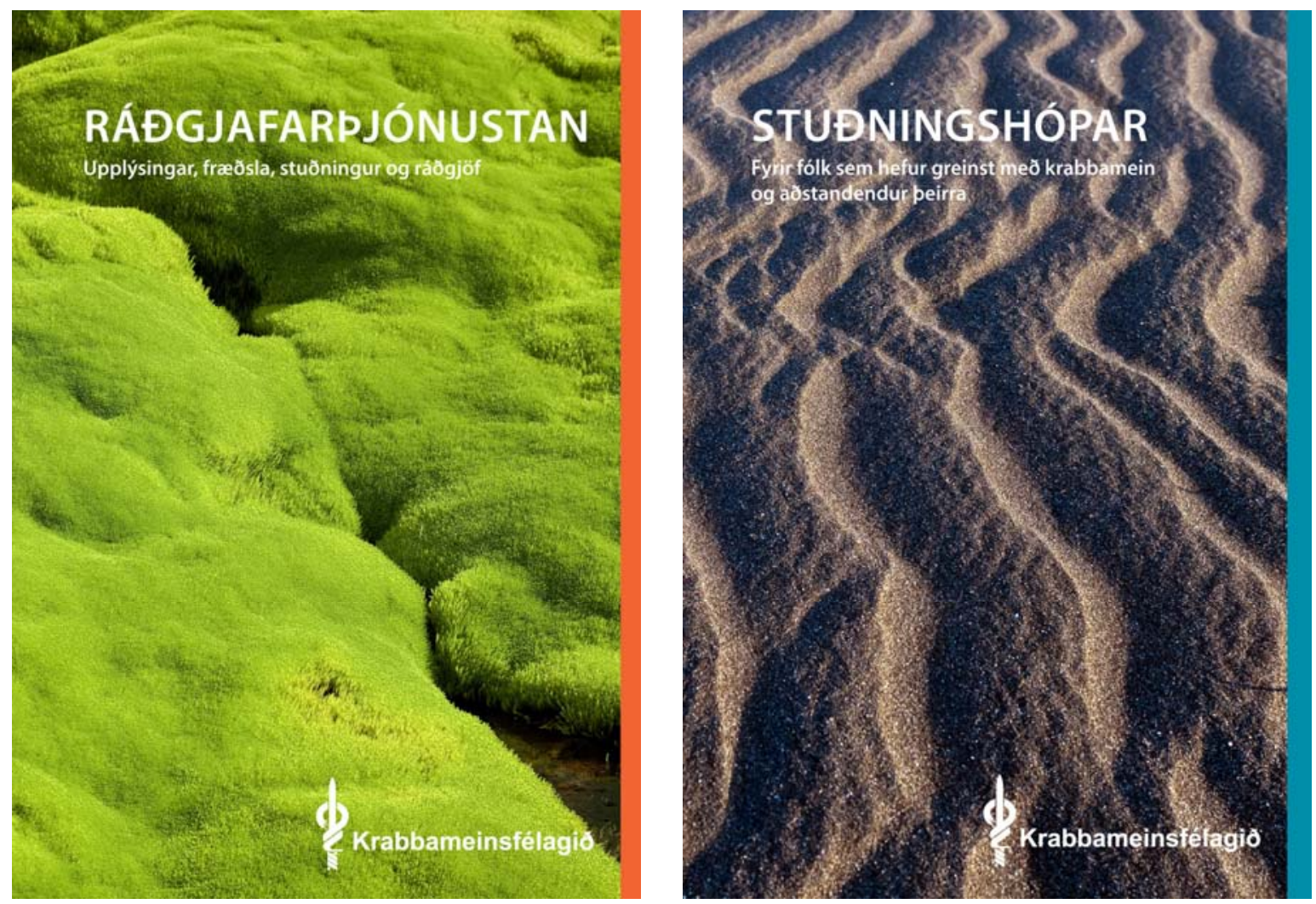


\section{Íbúðirnar á Rauðarárstíg}

Íbúðir fyrir krabbameinssjúklinga og aðstandendur peirra af landsbyggðinni, til afnota á meðan meðferð fer fram í Reykjavík, eru átta talsins, allar að Rauðarárstíg 33. Sex peirra eru eign Krabbameinsfélags Íslands og Rauða kross Íslands, ein eign Krabbameinsfélags Íslands og Hússjóðs Öryrkjabandalagsins og ein eign Krabbameinsfélags Íslands. Ráðgjafarbjónustan ber ábyrgð á íbúðum félagsins en Landspítali sér um daglegan rekstur. Nánari upplýsingar má fá á móttöku geislameðferðar krabbameina á Landspítala við Hringbraut í síma 5436800 og 5436801.

Íbúðirnar hafa verið vel nýttar og langflestir hafa fengið íbúð pegar sótt er um. Úthlutun á íbúðunum fer fram á geisladeild Landspítala. Kostnaður er nú 1.900 kr. á sólarhring fyrir leigutaka. Sum krabbameinsfélög á landsbyggðinni taka pátt í greiðslu kostnaðar við dvöl í íbúðunum.

Gjafir frá aðildarfélögum og fleirum hafa gert okkur kleift að endurnýja húsbúnað, meðal annars voru keypt prjú ný sjónvarpstæki, endurnýjaðar voru ryksugur, auk annars viðhalds. Á árinu 2014 kom gjöf frá Krabbavörn í Vestmannaeyjum en pau hafa stutt petta verkefni dyggilega á undanförnum árum. Stuðningurinn er ómetanlegur og kemur sér vel fyrir pann hóp sem nýtir íbúðirnar.

Sigrún Lillie Magnúsdóttir og Steinunn Friðriksdóttir.

\section{Íbúðir fyrir krabbameinssjúklinga að Rauðarárstíg 33 í Reykjavík.}

\begin{tabular}{|c|c|c|c|c|c|c|}
\hline & $\begin{array}{l}\text { Tekin í } \\
\text { notkun }\end{array}$ & $\begin{array}{r}\text { Nýting } \\
2010\end{array}$ & $\begin{array}{r}\text { Nýting } \\
2011\end{array}$ & $\begin{array}{r}\text { Nýting } \\
2012\end{array}$ & $\begin{array}{r}\text { Nýting } \\
2013\end{array}$ & $\begin{array}{r}\text { Nýting } \\
2014\end{array}$ \\
\hline Íbúð 201 & 16.03 .1995 & 35 vikur & 46 vikur & 48 vikur & 51 vika & 50 vikur \\
\hline Íbúð 202 & 16.03 .1995 & 42 vikur & 40 vikur & 45 vikur & 48 vikur & 50 vikur \\
\hline Íbúð 203 & 06.08.1996 & 32 vikur & 42 vikur & 44 vikur & 34 vikur & 47 vikur \\
\hline Íbúð 204 & 03.05.2003 & 46 vikur & 40 vikur & 47 vikur & 48 vikur & 45 vikur \\
\hline Íbúð 205 & 11.12.1992 & 39 vikur & 41 vika & 46 vikur & 34 vikur & 48 vikur \\
\hline Íbúð 206 & 27.06.2001 & 41 vika & 42 vikur & 49 vikur & 42 vikur & 50 vikur \\
\hline Íbúð 207 & 17.01.2005 & 40 vikur & 33 vikur & 44 vikur & 42 vikur & 44 vikur \\
\hline Íbúð 306 & 03.05.2002 & 48 vikur & 46 vikur & 46 vikur & 39 vikur & 45 vikur \\
\hline Meðaltal & & 40 vikur & 41 vika & 46 vikur & 42 vikur & 47 vikur \\
\hline
\end{tabular}

\section{Nýting eftir landshlutum 2014.}

Akureyri og Eyjafjörður

Austfirðir og Austurland

Vestfirðir

Vestmannaeyjar

Skagafjörður

Suðausturland

pingeyjarsýslur

Aðrir landshlutar

Samtals
(Krabbameinsfélag Akureyrar og nágrennis) (Krabbameinsf. Austfjarða og Krabbameinsf. Austurlands) (Krabbameinsf. Táknafj. og Vesturb. og Sigurvon) (Krabbavörn Vestmannaeyjum) (Krabbameinsfélag Skagafjarðar) (Krabbameinsfélag Suðausturlands) (Krabb S-Dingeyinga og Krabb. Norðausturlands)
23 sjúklingar 14 sjúklingar 10 sjúklingar 8 sjúklingar 5 sjúklingar 4 sjúklingar 4 sjúklingar 16 sjúklingar 84 sjúklingar 


\section{Krabbameinsskráin}

Krabbameinsskráin fagnaði á síðasta ári 60 ára afmæli sínu og hefur nú tiltækar upplýsingar um nýgreind krabbamein fyrir alla pjóðina í heila sex áratugi. Skráin er ein fárra lýðgrundaðra skráa sem taka til heilla pjóða í heiminum. Hún var stofnuð um svipað leyti og krabbameinsskrár á hinum norrænu löndunum og eru pessar skrár allar mjög sambærilegar hvað varðar upplýsingar, pekjun og áreiðanleika gagna. Tölulegar upplýsingar um krabbamein á Íslandi birtast árlega á vefsíðu Krabbameinsskrárinnar (krabbameinsskra.is) og í norræna gagnagrunninum NORDCAN (www.ancr.nu), auk pess að birtast á fjögurra ára fresti í bókinni Krabbamein á Íslandi, sem hefur komið út prisvar, síðast árið 2012.

Skráð eru í einn grunn öll krabbamein sem greinast á Íslandi og eftir atvikum skyldir sjúkdómar eða viðurkenndar forstigsbreytingar æxlisvaxtar. Á undanförnum árum hafa í vaxandi mæli verið skráðar ítarlegri upplýsingar um meinin og er einkum framför að skráningu á sjúkdómsstigi við greiningu í algengustu meinunum. Krabbameinsskráin er haldin með pað fyrir augum að hinar skrásettu upplýsingar megi nota til faraldsfræðilegra rannsókna á orsökum krabbameina, stjórnunar og áætlanagerðar í heilbrigðispjónustu, gæðaeftirlits og athugana á árangri við meðferð og skimun. Ennfremur er einn megintilgangur Krabbameinsskrárinnar að hafa tiltækar réttar tölfræðiupplýsingar um krabbamein í landinu t.d. með upplýsingum um nýgengi krabbameina og horfur krabbameinssjúklinga til pess, meðal annars að unnt sé að bera saman slíkar tölur frá Íslandi við tölur frá öðrum löndum og breytingar á peim með tímanum.

Krabbameinsskráin skiptist í skráningardeild, faraldsfræðideild og ættadeild. Yfirlæknir er Jón Gunnlaugur Jónasson meinafræðingur og prófessor við læknadeild Háskóla Íslands, en framkvæmdastjóri er Laufey Tryggvadóttir faraldsfræðingur og klínískur prófessor við Háskóla Íslands. Annað starfsfólk er Elínborg Jóna Ólafsdóttir sérfræðingur, Guðríður H. Ólafsdóttir gagnagrunnsstjóri, Hrefna Stefánsdóttir og Kristín Alexíusdóttir sem vinna við skráningu og rannsóknir, Sigrún Stefánsdóttir deildarstjóri skráningar og Porgils Völundarson forritari. Lára G. Sigurðardóttir læknir er í hlutastarfi við verkefni tengd rannsóknum á virkni bóluefnis gegn leghálskrabbameini. Loks vinna einn eða fleiri háskólanemar að jafnaði að vísindaverkefnum við Krabbameinsskrána. Föst stöðugildi eru 6, en verkefnavinna par fyrir utan er fjármögnuð með styrkjum.

Krabbameinsskráin hefur verið rekin af Krabbameinsfélagi Îslands frá upphafi en síðustu áratugi með góðum stuðningi frá velferðarráðuneytinu. Með lögum um landlækni frá 1. september 2007 fékk Krabbameinsskráin formlega lagastoð, en par er hún skilgreind sem ein af peim heilbrigðisskrám sem landlækni ber að halda. Í kjölfarið gerðu landlæknir og Krabbameinsfélag Íslands með sér samning sem kvað á um að félagið tæki að sér áframhaldandi rekstur skrárinnar í umboði landlæknis.

Breytingar á nýgengi eru sýndar í töflu 1. Árlegur fjöldi krabbameinsgreininga er nú 1.439 eins og sést í töflu 2. Stöðugt fjölgar peim sem eru á lífi eftir greiningu krabbameins og í árslok 2013 var fjöldinn nálægt 12.750 manns, eða 3,9\% pjóðarinnar (tafla 3), en í árslok 1963 var hlutfallið 0,4\%. Í töflu 4 sést að fimm ára hlutfallsleg lifun hefur aukist mikið fyrir flest mein og sem dæmi má nefna leghálskrabbamein hjá konum. Ánægjulegt er einnig að sjá að um tveir af hverjum premur sem greinast með krabbamein geta vænst pess að lifa fimm ár eða lengur eftir greiningu og á petta við um bæði kyn (tafla 4).

Myndir 1-6 sýna breytingar á nýgengi og dánartíðni með tímanum, fyrir tíðustu mein kynjanna og öll mein saman. Tölurnar eru aldursstaðlaðar miðað við albjóðlegan aldursstaðal og eru sýndar sem fimm ára hlaupandi meðaltöl. Upplýsingar um dánarmein eru frá Hagstofu Íslands (1951-2009) og Embætti landlæknis (2010).

Frá upphafi skráningar var stöðug hækkun á nýgengi krabbameina í heildina séð, fram til aldamóta. Nýgengið hefur staðið í stað hjá konum eftir pað og vart er við lækkun hjá körlum allra síðustu ár. Dánartíðnin var nokkuð stöðug frá upphafi og fram til aldamóta en hefur farið lækkandi síðan, hjá báðum kynjum. 
Tafla 1. Breytingar á nýgengi algengustu meina 1959-2013.

Árlegt aldursstaðlað nýgengi af 100.000 (miðað við alpjóðlegan aldursstaðal).

\section{Karlar}

Krabbamein í blöðruhálskirtli

Lungnakrabbamein

Krabbamein í pvagvegum *

Krabbamein í ristli

Húðkrabbamein, önnur en sortuæxli

Nýrnakrabbamein

Heilaæxli og önnur æxli í miðtaugakerfi

Eitilfrumuæxli **

Endaparmskrabbamein

Sortuæxli í húð

Krabbamein í vélinda

Langvinnt hvítblæði

Krabbamein í brisi

Magakrabbamein

Krabbamein í eistum

Öll mein

Konur

Brjóstakrabbamein

Lungnakrabbamein

Krabbamein í ristli

Húðkrabbamein, önnur en sortuæxli

Sortuæxli í húd

Krabbamein í legbol

Krabbamein í skjaldkirtli

Heilaæxli og önnur æxli í miðtaugakerfi

Leghálskrabbamein

Nýrnakrabbamein

Eitilfrumuæxli **

Krabbamein í eggjastokkum

Krabbamein í pvagvegum *

Endaparmskrabbamein

Krabbamein í brisi

Öll mein

$\begin{array}{rrrrrrrrrrr}1959 & 1964 & 1969 & 1974 & 1979 & 1984 & 1989 & 1994 & 1999 & 2004 & 2009 \\ -1963 & -1968 & -1973 & -1978 & -1983 & -1988 & -1993 & -1998 & -2003 & -2008 & -2013 \\ & & & & & & & & & & \\ 15,7 & 25,3 & 26,5 & 34,2 & 45,0 & 54,8 & 62,1 & 78,4 & 89,3 & 102,6 & 81,7 \\ 14,7 & 14,7 & 17,9 & 22,8 & 32,7 & 34,7 & 34,7 & 36,4 & 34,9 & 35,0 & 30,3 \\ 6,3 & 7,7 & 11,9 & 14,0 & 22,5 & 22,0 & 20,5 & 22,6 & 21,2 & 22,7 & 23,5 \\ 10,2 & 11,1 & 12,3 & 13,1 & 17,4 & 19,4 & 17,0 & 21,2 & 23,3 & 23,7 & 20,5 \\ 2,7 & 2,4 & 3,1 & 4,3 & 4,6 & 5,7 & 5,6 & 8,1 & 9,5 & 12,5 & 17,0 \\ 9,6 & 11,5 & 12,0 & 9,4 & 12,5 & 10,6 & 14,8 & 15,7 & 12,7 & 14,3 & 14,5 \\ 7,4 & 8,1 & 8,2 & 8,7 & 7,9 & 9,6 & 13,3 & 11,9 & 9,6 & 11,5 & 11,0 \\ 2,2 & 3,1 & 4,0 & 3,9 & 5,2 & 7,0 & 8,6 & 10,2 & 10,5 & 10,4 & 10,2 \\ 3,7 & 8,5 & 6,1 & 7,3 & 7,9 & 8,0 & 6,0 & 8,2 & 8,0 & 9,0 & 9,1 \\ 0,8 & 1,4 & 1,0 & 2,1 & 4,0 & 3,0 & 3,8 & 7,6 & 9,7 & 10,3 & 8,3 \\ 8,3 & 5,4 & 4,0 & 4,4 & 4,8 & 3,8 & 5,7 & 6,0 & 4,8 & 6,1 & 7,1 \\ 5,3 & 1,9 & 3,2 & 4,6 & 3,3 & 4,6 & 3,3 & 4,5 & 4,9 & 5,4 & 6,1 \\ 6,0 & 8,5 & 8,7 & 10,5 & 9,8 & 10,4 & 8,9 & 8,4 & 8,0 & 7,1 & 6,1 \\ 64,3 & 46,1 & 39,6 & 32,8 & 29,7 & 26,0 & 20,7 & 14,2 & 10,7 & 9,0 & 5,8 \\ 1,7 & 1,5 & 3,0 & 3,1 & 2,6 & 5,3 & 6,0 & 5,8 & 5,1 & 5,7 & 5,2\end{array}$

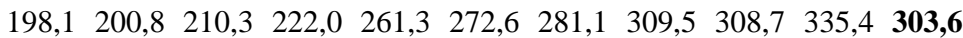

$\begin{array}{lllllllllll}1959 & 1964 & 1969 & 1974 & 1979 & 1984 & 1989 & 1994 & 1999 & 2004 & 2009\end{array}$

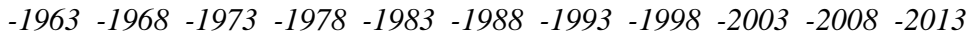

$\begin{array}{rrrrrrrrrrr}40,7 & 47,9 & 47,3 & 57,7 & 60,5 & 75,3 & 69,5 & 75,5 & 85,4 & 88,5 & 91,1 \\ 6,1 & 9,4 & 11,6 & 16,2 & 23,8 & 27,8 & 28,6 & 31,4 & 33,1 & 32,4 & 32,8 \\ 10,5 & 12,0 & 14,5 & 15,1 & 13,3 & 14,9 & 14,5 & 15,4 & 14,1 & 17,7 & 15,7 \\ 1,7 & 0,9 & 1,7 & 3,2 & 2,3 & 3,6 & 4,8 & 4,9 & 9,9 & 9,8 & 13,4 \\ 1,8 & 3,2 & 2,9 & 5,2 & 5,6 & 5,3 & 7,7 & 12,1 & 19,3 & 15,5 & 12,7 \\ 11,5 & 12,5 & 13,4 & 12,6 & 12,0 & 12,6 & 13,4 & 13,8 & 11,4 & 13,2 & 11,6 \\ 7,7 & 11,1 & 18,2 & 15,7 & 9,6 & 8,8 & 10,8 & 11,4 & 9,8 & 12,3 & 10,7 \\ 6,8 & 7,4 & 7,4 & 7,8 & 12,3 & 10,1 & 11,9 & 12,3 & 12,6 & 14,8 & 9,8 \\ 16,9 & 27,3 & 18,1 & 10,3 & 13,1 & 11,2 & 9,1 & 9,6 & 8,9 & 7,9 & 8,9 \\ 6,5 & 5,7 & 8,1 & 7,5 & 7,3 & 7,7 & 7,8 & 7,7 & 7,6 & 9,0 & 7,6 \\ 1,5 & 1,6 & 2,0 & 3,4 & 4,7 & 3,3 & 4,8 & 5,8 & 6,3 & 6,3 & 7,3 \\ 12,9 & 12,3 & 12,9 & 13,6 & 12,4 & 14,1 & 12,1 & 11,4 & 9,7 & 7,8 & 7,0 \\ 4,1 & 4,1 & 6,6 & 5,7 & 5,4 & 8,2 & 5,2 & 7,6 & 7,2 & 7,2 & 6,0 \\ 4,6 & 5,6 & 6,8 & 4,9 & 5,7 & 5,4 & 5,8 & 5,6 & 7,2 & 7,2 & 5,7 \\ 3,7 & 9,1 & 6,5 & 5,9 & 7,3 & 6,7 & 7,0 & 7,4 & 5,6 & 5,6 & 5,4\end{array}$

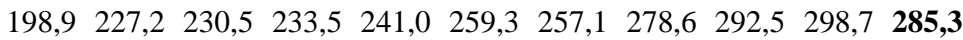

* Krabbamein í pvagvegum (pvagblöðru o.fl.) ** Eitilfrumuæxli (önnur en Hodgkins-eitilfrumuæxli) 
Tafla 2. Árlegur meðalfjöldi algengustu krabbameina hjá íslenskum körlum og konum 2009-2013.

Raðað eftir fjölda nýrra tilfella á ári.

\section{Karlar}

1. Krabbamein í blöðruhálskirtli

2. Lungnakrabbamein

3. Krabbamein í pvagvegum*

4. Krabbamein í ristli

5. Húðkrabbamein, önnur en sortuæxli ......... 50

6. Nýrnakrabbamein .................................... 32

7. Eitilfrumuæxli** ...................................... 23

8. Heilaæxli og önnur æxli í miðtaugakerfi ... 22

9. Endaparmskrabbamein ............................. 21

10. Sortuæxli í húð

Öll mein
201

77

61

52

50

2

3

21

740

\section{Konur}

1. Brjóstakrabbamein ................................. 208

2. Lungnakrabbamein ................................. 85

3. Krabbamein í ristli ................................... 46

4. Húðkrabbamein, önnur en sortuæxli ........ 45

5. Krabbamein í legbol ................................. 27

6. Sortuæxli í húð ........................................ 25

7. Krabbamein í skjaldkirtli .......................... 22

8. Heilaæxli og önnur æxli í miðtaugakerfi ... 21

9. Nýrnakrabbamein ..................................... 19

10. Eitilfrumuæxli** ..................................... 18

Öll mein 699

* Krabbamein í pvagvegum (pvagblöðru o.fl.) ** Eitilfrumuæxli (önnur en Hodgkins-eitilfrumuæxli)

Tafla 3. Fjöldi einstaklinga á lífi eftir greiningu krabbameins. Algengustu meinin.

Fjöldi á lífi í árslok 2013.

Brjóstakrabbamein

Krabbamein í blöðruhálskirtli

Krabbamein í ristli

Sortuæxli í húð

Húðkrabbamein, önnur en sortuæxli

Krabbamein í pvagvegum (pvagblöðru o.fl.)

Krabbamein í skjaldkirtli

Heilaæxli og önnur æxli í miðtaugakerfi

Nýrnakrabbamein

Lungnakrabbamein

Krabbamein í legbol

Eitilfrumuæxli (önnur en Hodgkins-eitilfrumuæxli)

Leghálskrabbamein

Endaparmskrabbamein

Krabbamein í eistum

Breytingar á fjölda á lífi á síðustu 50 árum

Fjöldi á lífi í árslok 1963

Fjöldi á lífi í árslok 1973

Fjöldi á lífi í árslok 1983

Fjöldi á lífi í árslok 1993

Fjöldi á lífi í árslok 2003

Fjöldi á lífi í árslok 2013

$\begin{array}{rrr}\text { Karlar } & \text { Konur } & \text { Alls } \\ 23 & 2.788 & 2.811 \\ 2.044 & & 2.044 \\ 429 & 392 & 821 \\ 261 & 509 & 770 \\ 361 & 382 & 743 \\ 522 & 167 & 689 \\ 134 & 470 & 604 \\ 192 & 316 & 508 \\ 272 & 191 & 463 \\ 189 & 258 & 447 \\ & 412 & 412 \\ 231 & 173 & 404 \\ & 369 & 369 \\ 177 & 158 & 335 \\ 269 & & 269\end{array}$

$\begin{array}{rrr}\text { Karlar } & \text { Konur } & \text { Alls } \\ 324 & 496 & 820 \\ 723 & 1.236 & 1.959 \\ 1.420 & 2.218 & 3.638 \\ 2.285 & 3.260 & 5.545 \\ 3.636 & 4.808 & 8.444 \\ 5.666 & 7.075 & \mathbf{1 2 . 7 4 1}\end{array}$


Tafla 4. Fimm ára hlutfallsleg lifun fólks sem hefur greinst með krabbamein.

Nokkur valin mein.

Karlar

Krabbamein í eistum

Húðkrabbamein, önnur en sortuæxli

Hodgkins eitilfrumuæxli

Krabbamein í blöðruhálskirtli

Krabbamein í skjaldkirtli

Sortuæxli í húð

Krabbamein í pvagvegum *

Eitilfrumuæxli **

Krabbamein í barkakýli

Endaparmskrabbamein

Krabbamein í ristli

Magakrabbamein

Krabbamein í vélinda

Lungnakrabbamein

Öll mein

Konur

Húðkrabbamein, önnur en sortuæxli

Langvinnt hvítblæði

Sortuæxli í húð

Krabbamein í skjaldkirtli

Brjóstakrabbamein

Leghálskrabbamein

Hodgkins eitilfrumuæxli

Krabbamein í legbol

Eitilfrumuæxli **

Endaparmskrabbamein

Krabbamein í pvagvegum *

Krabbamein í ristli

Magakrabbamein

Lungnakrabbamein

Öll mein
1960-1969

1970-1979

$83 \%$

$66 \%$

$30 \%$

$30 \%$

$72 \%$

$63 \%$

$57 \%$

$33 \%$

$63 \%$

$39 \%$

$40 \%$

$12 \%$

$0 \%$

$7 \%$

$27 \%$

1960-1969

1970-1979

1980-1989

$75 \%$

$22 \%$

$55 \%$

$85 \%$

$69 \%$

$57 \%$

$33 \%$

$79 \%$

$14 \%$

$44 \%$

$50 \%$

$25 \%$

$20 \%$

$5 \%$

$44 \%$

\section{$63 \%$}

$59 \%$

$57 \%$

$90 \%$

$42 \%$

$74 \%$

$45 \%$

$58 \%$

$33 \%$

$46 \%$

$15 \%$

$6 \%$

$9 \%$

$38 \%$

$92 \%$

$43 \%$

$81 \%$

$90 \%$

$73 \%$

$71 \%$

$63 \%$

$73 \%$

$43 \%$

$48 \%$

$60 \%$

$51 \%$

$19 \%$

$10 \%$

$51 \%$
1980-1989

$94 \%$

$98 \%$

$85 \%$

$64 \%$

$91 \%$

$81 \%$

$75 \%$

$46 \%$

$65 \%$

$51 \%$

$45 \%$

$22 \%$

$24 \%$

$12 \%$

$47 \%$

$100 \%$

$46 \%$

$89 \%$

$90 \%$

$78 \%$

$81 \%$

$89 \%$

$75 \%$

$66 \%$

$56 \%$

$68 \%$

$53 \%$

$31 \%$

$14 \%$

$56 \%$
1990-1999

$100 \%$

$91 \%$

$97 \%$

$79 \%$

$87 \%$

$79 \%$

$77 \%$

$56 \%$

$65 \%$

$53 \%$

$54 \%$

$27 \%$

$11 \%$

$12 \%$

55\%

1990-1999

2000-2009

100\%

$100 \%$

93\%

$96 \%$

$85 \%$

$75 \%$

$63 \%$

$74 \%$

$56 \%$

$50 \%$

$65 \%$

$54 \%$

$29 \%$

$14 \%$

$60 \%$

$96 \%$

95\%

95\%

91\%

$90 \%$

$86 \%$

$84 \%$

$75 \%$

$73 \%$

$72 \%$

$65 \%$

$43 \%$

$16 \%$

70\%

* Krabbamein í pvagvegum (pvagblöðru o.fl.) ** Eitilfrumuæxli (önnur en Hodgkins-eitilfrumuæxli) 


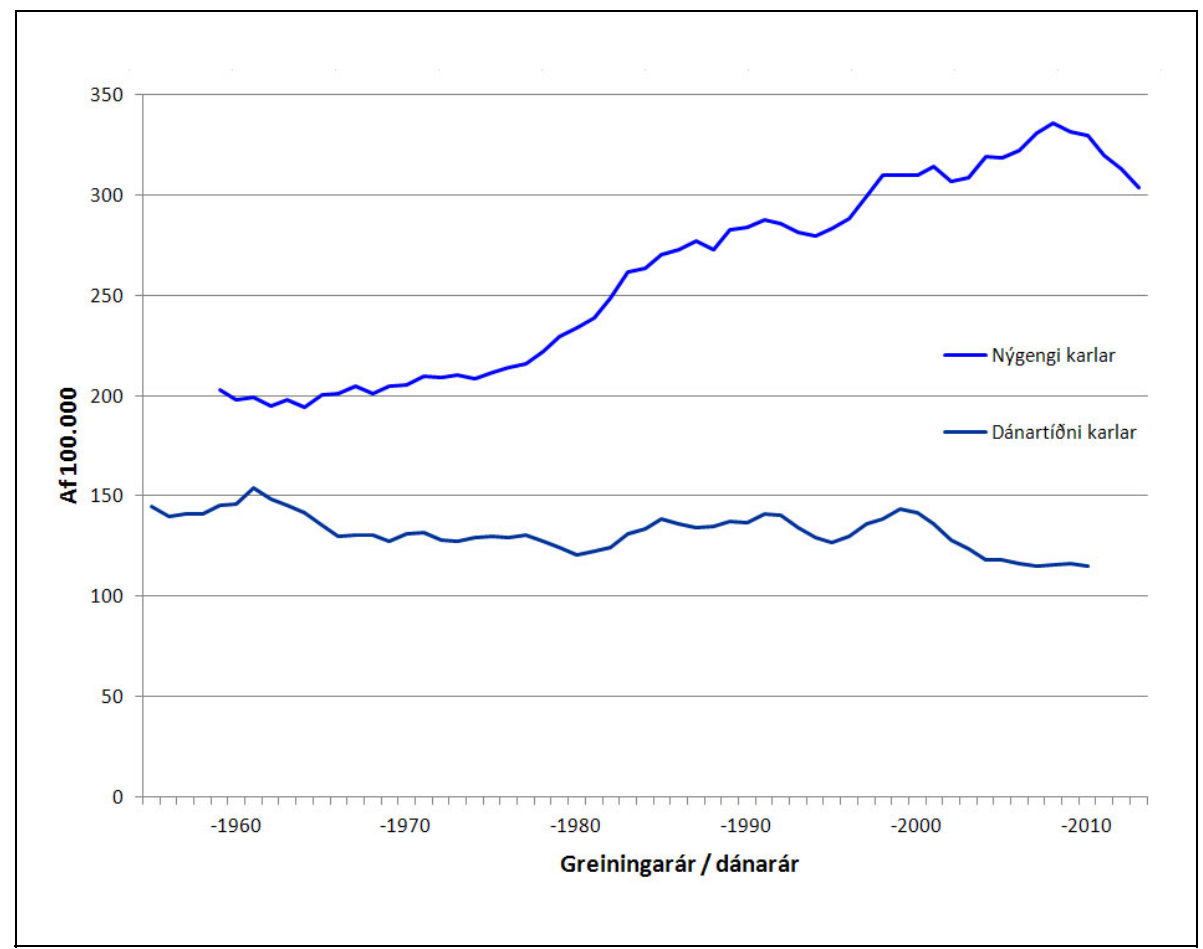

Mynd 1:

Öll krabbamein.

Karlar.

Breytingar á nýgengi og dánartíðni.*

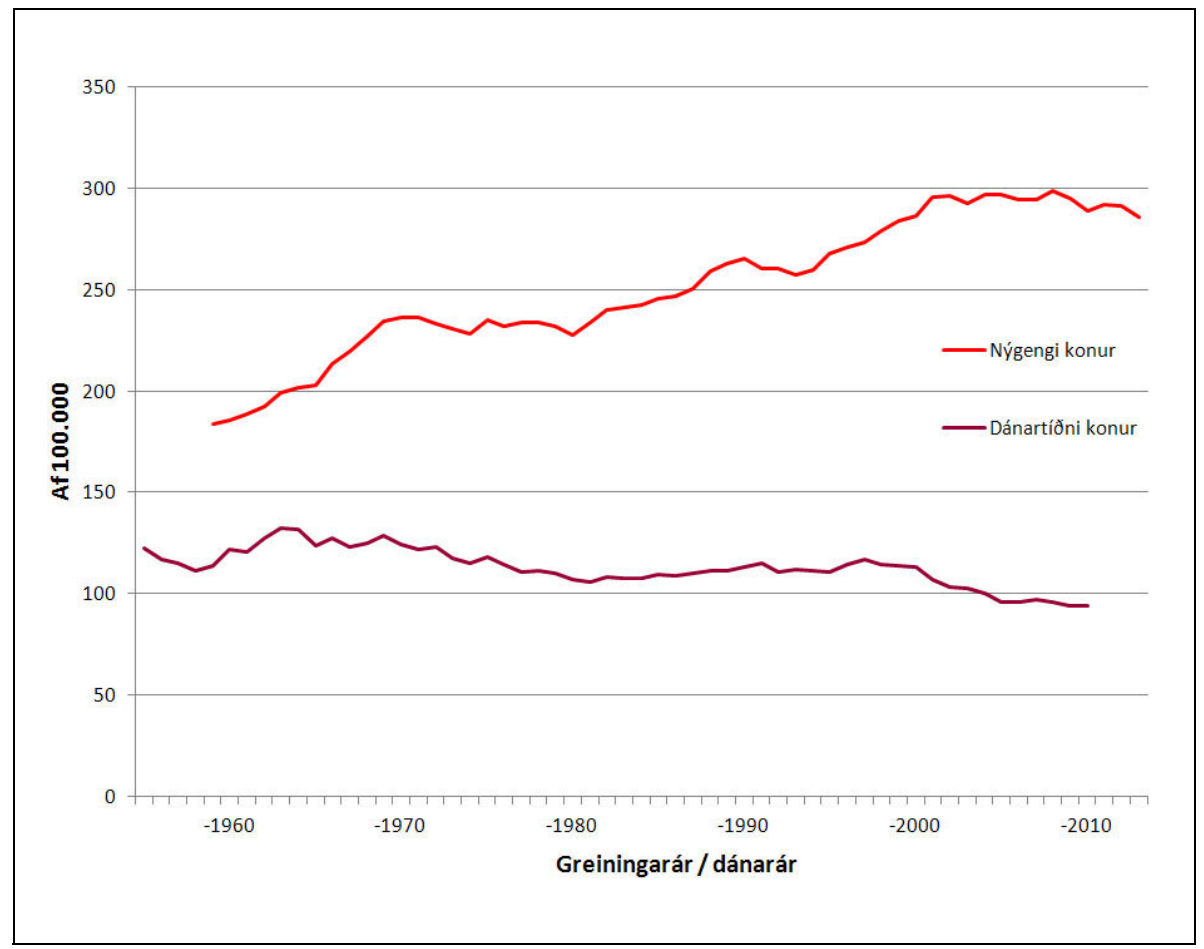

Mynd 2:

Öll krabbamein.

Konur.

Breytingar á nýgengi og dánartíðni.*

* Miðað við 100.000, aldursstaðlað (alheimsstaðall), fimm ára hlaupandi meðaltöl. 


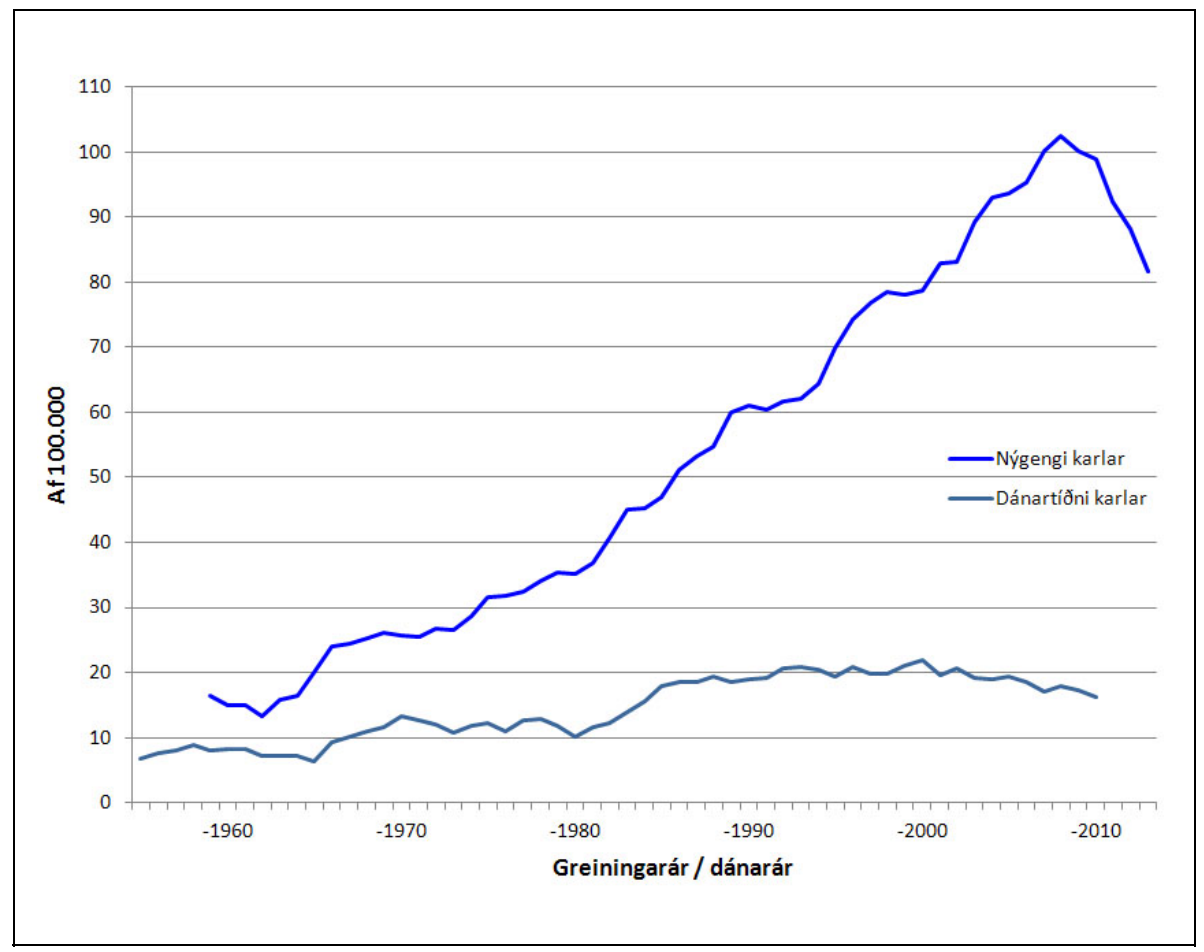

Mynd 3:

Blöðruhálskirtilskrabbamein. Breytingar á nýgengi og dánartíðni.*

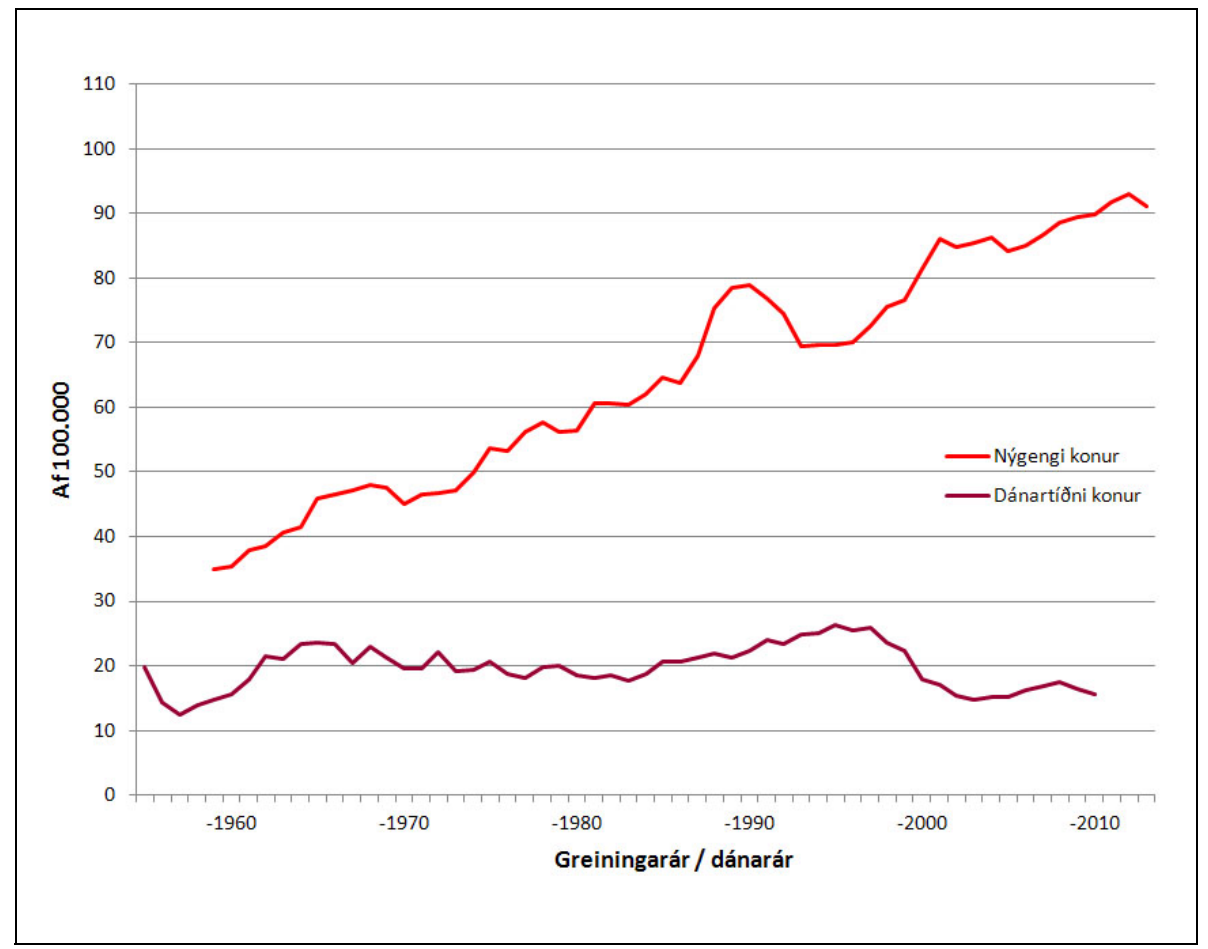

Mynd 4:

Brjósta-

krabbamein.

Breytingar á nýgengi og dánartíðni.*

* Miðað við 100.000, aldursstaðlað (alheimsstaðall), fimm ára hlaupandi meðaltöl. 


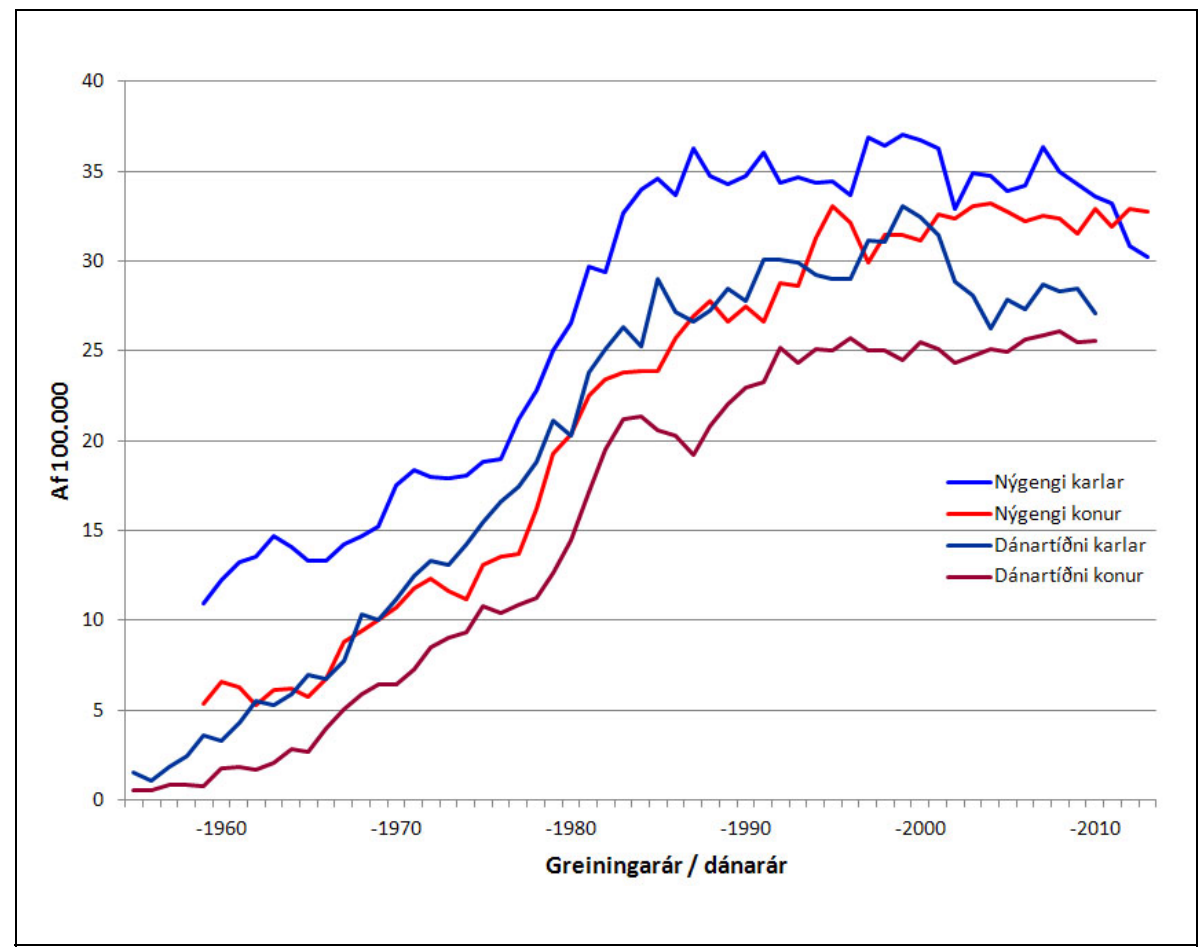

Mynd 5:

Lungna-

krabbamein.

Breytingar á nýgengi og dánartíðni.*

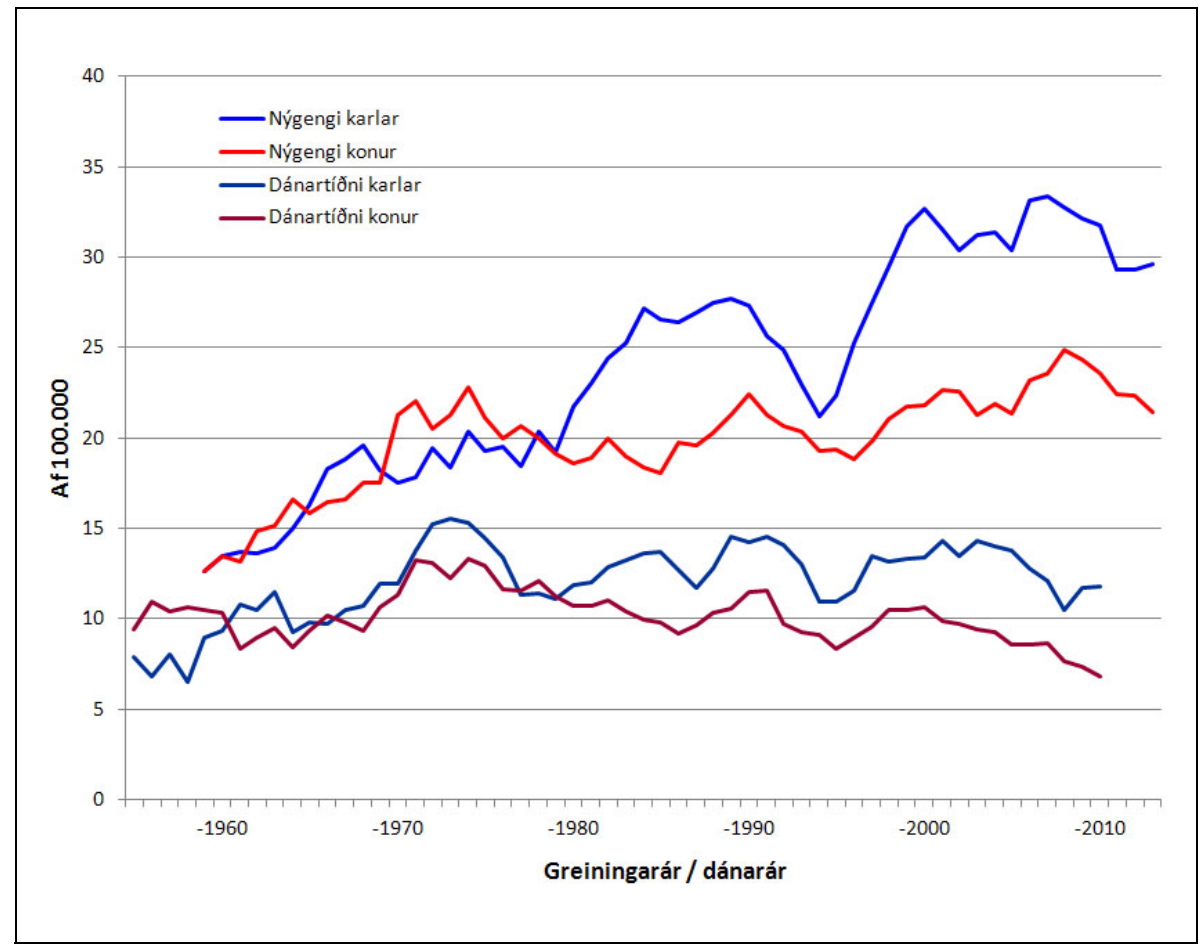

Mynd 6:

Ristilkrabbamein.

Breytingar á nýgengi og dánartíoni.*

* Miðað við 100.000, aldursstaðlað (alheimsstaðall), fimm ára hlaupandi meðaltöl. 


\section{Leitarstöð Krabbameinsfélagsins}

Leghálskrabbameinsleitin hófst árið 1964. Tímamótanna var minnst með sameiginlegri afmælisráðstefnu Leitarstöðvarinnar og Krabbameinsskrárinnar 9. maí 2015. Auk innlendra fyrirlesara flutti Stefan Lönnberg yfirmaður leghálskrabbameinsleitarinnar í Noregi fyrirlestur um „Future prospects of cervical cancer screening“ og Mireille Broeders vísindamaður við miðstöð í læknavísindum við Radboud háskóla í Nijmegen í Hollandi fyrirlestur um „Benefits and harms of mammography screening“.

Frá árinu 1969 og til ársloka 1987 takmarkaðist leitarstarfið við 25-69 ára konur og voru pær boðaðar til leitar á tveggja til priggja ára fresti. Samhliða pjónustusamningi við heilbrigðisráðuneytið 1. janúar 1988 voru neðri aldursmörk færð niður í 20 ár og boðað var til leitar á tveggja ára fresti. Á miðju ári 2009 var boðun breytt á pann hátt að konur á aldrinum 40-69 ára voru boðaðar á fjögurra ára fresti svo fremi pær hefðu fimm eðlileg frumustrok og par af tvö á síðustu fimm árum.

Pann 1. janúar 2014 voru gerðar breytingar á markhópi og aldursbili leitar en pá var aldur við fyrstu skoðun hækkaður úr 20 árum í 23 ár, aldur við síðustu skoðun lækkaður úr 69 árum í 65 ár og bil milli boðunar var lengt úr tveimur árum í prjú ár. Einnig var grindarpreifingu hætt hjá einkennalausum konum. Eyðublað vegna leghálssýna var endurskoðað og einfaldað á starfsárinu. Tekin voru upp vökvasýni á landsbyggðinni. Húsnæði Leitarstöðvar var endurskipulagt pannig að nú parf engin kona að sitja í slopp einum klæða á biðstofu. Leghálssýnataka á landsbyggðinni var færð til heilbrigðisstofnana með pátttöku ljósmæðra sem hafa fengið pjálfun hjá Leitarstöðinni og nú er öllum konum á landsbyggðinni boðin leghálskrabbameinsleit með sama sniði og á höfuðborgarsvæðinu. Boðsbréf og lokabréfum var breytt og pau endurskoðuð. Í nóvember birtist úrskurður Persónuverndar um að Landspítala væri heimilt að veita Leitarstöðinni upplýsingar um konur sem höfðu gengist undir fullkomið legnám og er pað mikill áfangi pví pær konur hafa ekki gagn af leghálskrabbameinsleit ef pær hafa ekki greinst áður með hátt forstig (CIN2+). Unnið er að pvíi að pessar konur fái ekki boð í leghálskrabbameinsleit, leit sem er gagnslaus og kostnaðarsöm fyrir konuna og pjóðfélagið.

Tilraunaaðgangur að leitarsögu var opnaður í september 2013 og virkjaður fyrir alla lækna með auðkenniskort í gegnum gátt Embættis landlæknis frá og með 1. janúar 2014. Aðgangurinn veitir upplýsingar um hvenær síðasta leghálssýni var tekið og hvenær mælt er með nýju sýni. Detta ætti að geta komið í veg fyrir oftöku leghálssýna sem hefur verið a.m.k. 35\% og pannig komið í veg fyrir ofgreiningar og oflækningar sem geta valdið konum líkamlegum skaða og peim og pjóðfélaginu fjárhagslegum kostnaði.

Í apríl 2014 opnaði vefsíðan hpv.is par sem öllum helstu spurningum um HPV er svarað og frumsýnt var fræðslumyndband um HPV og tilgang leghálskrabbameinsleitar. Bleiki mánuðurinn var helgaður vakningarvitund varðandi pátttöku í leghálskrabbameinsleit og ánægjulegt er að segja frá pví pátttaka í leghálskrabbameinsleit jókst um 3\% á árinu miðað við árið á undan og var 73\%. Bandaríska sóttvarnarstofnunin (CDC) telur að regluleg mæting í leghálskrabbameinsleit geti komið í veg fyrir 93\% leghálskrabbameina. Markmið Leitarstöðvarinnar er að pátttaka verði yfir 80\% ekki síðar en árið 2020.

Krabbameinsfélagið hefur gert samning við Karólínska sjúkrahúsið í Stokkhólmi um HPV-mælingar frá 1. janúar 2015 og hefðbundin glersýni voru aflögð 1. febrúar 2015 og einungis tekin vökvasýni frá peim tíma.

Brjóstakrabbameinsleitin var tengd leghálskrabbameinsleitinni til 1. janúar 2014 en pá voru pessi tengsl rofin vegna faglegra sjónarmiða. Orsök leghálskrabbameins er bekkt par sem kynsmit með HPV-veirum er orsakavaldurinn en orsök brjóstakrabbameins er ópekkt að mestu pó margir áhættupættir séu pekktir.

Frá 1973 voru brjóst kvenna preifuð um leið og pær komu til leghálskrabbameinsleitar. Ef eitthvað athugavert fannst voru konur sendar í nánari skoðun með brjóstaröntgenmyndatöku og fínnálarástungu (frá 1976). Í byrjun nóvember 1987, tveimur mánuðum fyrir gildistöku pjónustusamnings við heilbrigðisráðuneytið, hófst skipulögð leit að brjóstakrabbameini með brjóstaröntgenmyndatöku hjá konum 35 ára og 40-69 ára og um 
leið var brjóstapreifingu hætt hjá pessum aldurshópum. Frá 1. janúar 1990 var brjóstabreifingu hætt hjá aldurshópnum 20-29 ára og frá 1. janúar 1993 var brjóstaröntgenmyndatöku hætt hjá 35 ára konum. Frá janúar 1997 var felld niður hefðbundin brjóstapreifing læknis og konur í öllum aldurshópum hvattar til sjálfskoðunar brjósta. Ef konur eru óöruggar með eigin skoðun eða finna einkenni frá brjóstum er peim við hefðbundna krabbameinsleit vísað til brjóstapreifingar hjá peim lækni sem framkvæmir leghálsskoðunina. Utan hefðbundinnar leitar er konum með einkenni frá brjóstum, sem ekki hafa tilvísun frá lækni utan Leitarstöðvar, bent á að ræða við hjúkrunarfræðing á Leitarstöðinni sem ákveður hvort peim er vísað til sérstakrar læknisskoðunar hjá svonefndri brjóstamóttöku Leitarstöðvarinnar.

Krabbameinsfélag Íslands hefur frá upphafi borið faglega og rekstrarlega ábyrgð á framkvæmd legháls- og brjóstakrabbameinsleitar hér á landi. Í júlí 1987 var gerður pjónustusamningur milli félagsins og heilbrigðisráðuneytisins um pennan rekstur sem tryggði að ráðuneytið veitti fé til starfseminnar. Fyrsti samningur við ráðuneytið tók gildi 1. janúar 1988 en hefur síðan verið endurnýjaður fjórum sinnum. Nýr fimm ára samningur við ráðuneytið fyrir tímabilið 2009-2013 tók óformlega gildi í ársbyrjun 2009 en vegna ríkjandi efnahagsvandamála var hann ekki formlega undirritaður fyrr en í mars 2010. Undirritaður var bjónustusamningur við Sjúkratryggingar Íslands í október 2013 sem gildir fyrir tímabilið frá 1. janúar til 31. desember 2014 og hann síðan framlengdur um eitt ár og samið um að kostnaðargreina leitarstarfið á samningstímanum.

pegar samningur við Læknisfræðilega myndgreiningu (Röntgen Domus Medica) rann út í lok árs 2013 var röntgendeild Leitarstöðvarinnar endurstofnuð og ráðnir sérfræðingar í myndgreiningu, geislafræðingar og annað starfsfólk. Skortur á röntgenlæknum hefur ógnað starfseminni og síðla árs 2014 voru hafnar viðræður við Landspítala um tilfærslu á sérskoðunum brjósta til Landspítala. Vegna skorts á röntgenlæknum var konum á Akranesi og Keflavík beint til Leitarstöðvarinnar í Reykjavík og konum á Seyðisfirði til Egilsstaða.

Í lok árs 2014 voru föst stöðugildi á Leitarstöðinni 24,8 en voru 20,2 í lok árs 2013 en auk pess störfuðu verktakar í 1,6 stöðugildum en voru í 9,8 stöðugildum í lok árs 2013. Í árslok 2014 voru stöðugildi bví samtals 26,4 en höfðu verið 30,0 ári áður. Ástæður fækkunar starfsmanna má rekja til skipulagsbreytinga og hagræðingar í rekstri.

Markhópur leghálskrabbameinsleitar er 23-65 ára. Í árslok 2014 voru 90.950 konur á pessum aldri búsettar á landinu og par af fóru 20.724 (23\%) í leghálsskoðun (tafla 1). Miðað við árslok 2014 höfðu 73\% hópsins mætt síðustu prjú og hálft ár, 79\% síðustu fimm ár og 87\% síðustu tíu ár (tafla 3). Tæp 8\% höfðu aldrei mætt til leghálskrabbameinsleitar. Á árinu 2014 voru gerðar 23.158 skoðanir hjá 22.084 konum í leit að leghálskrabbameini (allir aldurshópar). Skoðaðar voru 13.127 konur (59\%) í Leitarstöðinni og á heilsugæslustöðvum og 8.957 (41\%) hjá sérfræðingum og sjúkrastofnunum (tafla 1).

Markhópur brjóstakrabbameinsleitar er 40-69 ára og var 50.076 kona á pessum aldri búsett hér á landi í árslok 2014. Fyrir landið í heild var tveggja ára pátttaka í pessum aldurshópi 60\% en petta pátttökuhlutfall hefur verið á bilinu 61-63\% frá árinu 1994 (tafla 5). Í árslok 2014 höfðu 15\% 40-69 ára kvenna aldrei mætt til brjóstakrabbameinsleitar með brjóstaröntgenmyndatöku.

Kristján Oddsson. 
Tafla 1: Leghálsskoðanir 2014 eftir aldurshópum. Fjöldi kvenna.

$$
\begin{array}{r}
\text { Leitarstöð og } \\
\text { heilsugæesla }
\end{array}
$$

19 ára og yngri

20-24 ára

25-29 ár

30-39 ára

40-49 ára

50-69 ára

70 ára og eldri

Fjöldi kvenna alls

- par af 23-65 ára
Sérfrcðingar og sjúkrastofnanir

12

1.022

1.347

2.185

3.244

5.131

186

13.127

8.957
Samtals

$\begin{array}{rr}19 & 31 \\ 891 & 1.913 \\ 1.596 & 2.943 \\ 2.883 & 5.068 \\ 1.865 & 5.109 \\ 1.610 & 6.741 \\ 93 & 279\end{array}$

20.724

\section{Tafla 2: Leghálsskoðanir 2014 eftir skoðunarstöðum. Fjöldi kvenna.}

Leitarstöðin í Reykjavík

10.298

Heilsugæslustöðvar utan höfuðborgarsvæðisins

Heilsugæslustöðvar á höfuðborgarsvæðinu

Kvensjúkdómalæknar á stofu

8.675

Sérfræðingar á sjúkrahúsum

Fjöldi kvenna alls

Tafla 3: Mæting 23-65 ára kvenna í leit að leghálskrabbameini, miðað við árslok 2014.

Mcett síðasta prjú og hálft ár

Reykjavíkurhérað

Vesturlandshérað

Vestfjarðahérað

Norðurlandshérað vestra

Norðurlandshérað eystra

Austurlandshérað

Suðurlandshérað

Reykjaneshérað

Landið í heild
$72 \%$

$73 \%$

$76 \%$

$70 \%$

$74 \%$

$77 \%$

$74 \%$

$74 \%$

$73 \%$
Mcett síðustu

fimm ár

$77 \%$

$80 \%$

$78 \%$

$83 \%$

$81 \%$

$83 \%$

$82 \%$

$80 \%$

$79 \%$
Mctt síðustu tíu ár

$85 \%$

$88 \%$

$83 \%$

$89 \%$

$89 \%$

$90 \%$

$86 \%$

$88 \%$

$87 \%$ 
Tafla 4: Ýmsar upplýsingar um leit að brjóstakrabbameini.

\begin{tabular}{lrrrrrrr} 
& 2008 & 2009 & 2010 & 2011 & 2012 & 2013 & 2014 \\
Fjöldi 40-69 ára kvenna sem komu í hópskoðun & 15.994 & 16.336 & 15.114 & 16.015 & 16.362 & 16.409 & 17.048 \\
Hlutfall endurinnkallaðra, 40-49 ára & $3,9 \%$ & $6,1 \%$ & $8,2 \%$ & $7,7 \%$ & $7,6 \%$ & $6,7 \%$ & $4,0 \%$ \\
Hlutfall endurinnkallaðra, 50-69 ára & $2,9 \%$ & $4,0 \%$ & $4,2 \%$ & $4,6 \%$ & $4,2 \%$ & $3,5 \%$ & $2,4 \%$ \\
\hline
\end{tabular}

Tafla 5: Mæting 40-69 ára kvenna í leit að brjóstakrabbameini, miðað við árslok 2014.

\begin{tabular}{|c|c|c|c|}
\hline & $\begin{array}{r}\text { Mcett síðustu } \\
\text { tvö ár }\end{array}$ & $\begin{array}{r}\text { Mcett síðustu } \\
\text { prjú ár }\end{array}$ & $\begin{array}{r}\text { Mcett síðustu } \\
\text { fjögur ár }\end{array}$ \\
\hline 40-44 ára & $56 \%$ & $63 \%$ & $65 \%$ \\
\hline 45-49 ára & $59 \%$ & $69 \%$ & $74 \%$ \\
\hline 50-54 ára & $60 \%$ & $71 \%$ & $76 \%$ \\
\hline 55-59 ára & $61 \%$ & $70 \%$ & $74 \%$ \\
\hline 60-64 ára & $61 \%$ & $71 \%$ & $74 \%$ \\
\hline 65-69 ára & $61 \%$ & $71 \%$ & $75 \%$ \\
\hline Landið í heild & $60 \%$ & $69 \%$ & $73 \%$ \\
\hline
\end{tabular}




\section{Frumurannsóknastofa}

Á frumurannsóknastofu Krabbameinsfélags Íslands eru rannsökuð frumusýni frá leghálsi kvenna. Flest sýnin eru tekin vegna hópleitar að forstigum leghálskrabbameins á vegum Leitarstöðvar Krabbameinsfélagsins. Einnig berast sýni frá konum sem eru í eftirliti vegna frumubreytinga og sýni sem tekin eru á stofu hjá sjálfstætt starfandi kvensjúkdómalæknum, ýmist í hópleit eða vegna einkenna hjá konunum. Starfsmenn frumurannsóknastofunnar vou 10 í árslok. Lífeindafræðingar, frumugreinir, líffræðingur og meinafræðingur í samtals 8,7 stöðugildum. Tveir starfsmenn, meinafræðingur og líffræðingur fóru á vegum Hologic á dagsping til Oslóar. Einnig fóru tveir á fund um leghálskrabbameinsleit á Norðurlöndum sem haldin var hjá Kreftregisteret í Osló

Vökvasýni eru tekin hjá konum sem koma til leghálskrabbameinsleitar í Leitarstöðina í Skógarhlíð. Í árslok var byrjað að taka vökvasýni á nokkrum stöðum úti á landi. Annars voru eins og áður tekin hefðbundin sýni í leit á landsbyggðinni og hjá konum sem fara á stofu hjá sérfræðingum.

Fjöldi sýna á frumurannsóknastofunni á árinu 2014 var 23.160. Í mars var aftur tekin upp endurskoðun 10\% eðlilegra sýna sem hluti af gæðaeftirliti. Forstigsbreytingar greindust í 1.588 sýnum eða 6,9\%. Áfram var hlutfall ófullnægjandi sýna lágt en hefur pó aldrei verið hærra en nú 1,4\%. Mælt var með leghálsspeglun og töku vefjasýnis 734 sinnum, en pað er gert ef kona er með alvarlegar forstigsbreytingar eða endurteknar vægar breytingar.

Ingibjörg Guðmundsdóttir og Auður Eiríksdóttir.

\section{Tafla 1: Fjöldi frumusýna frá leghálsi undanfarin fimm ár.}

$\begin{array}{lrrrrr} & 2010 & 2011 & 2012 & 2013 & 2014 \\ \text { Heildarfjöldi sýna } & 20.423 & 26.905 & 33.098 & 33.268 & 23.160 \\ \text { Hefðbundin frumusýni } & 10.442 & 15.595 & 19.990 & 19.610 & 12.466 \\ \text { Vökvasýni } & 9.981 & 11.310 & 13.107 & 13.658 & 10694 \\ \text { Hlutfall vökvasýna af öllum sýnum } & 48,9 \% & 42,0 \% & 39,6 \% & 41,1 \% & 46 \% \\ \text { Forstigsbreytingar } & 1.422 & 1.502 & 2.361 & 1.978 & 1.588 \\ \text { Hlutfall af öllum sýnum } & 7,0 \% & 5,6 \% & 7,1 \% & 5,9 \% & 6,9 \% \\ & & & & & \end{array}$

Tafla 2: Samanburður á niðurstöðum úr frumugreiningu og vefjagreiningu árið 2014. Vefjagreining

$\begin{array}{lll}\text { Eðlileg sýni, } & \text { Væegar } & \text { Meiriháttar forstigs- } \\ \text { bólga } & \text { forstigsbreytingar, } & \text { breytingar og } \\ & \text { veirubreytingar } & \text { ífarandi krabbamein }\end{array}$

Frumugreining

Endurteknar, vægar forstigsbreytingar

$60(16 \%)$

214 (57\%)

104 (27\%)

378

Óljósar forstigsbreytingar, meiriháttar breytingar, og ífarandi krabbamein

$43(12 \%)$

105 (30\%)

208 (58\%) 


\section{Ritskrá}

\section{Greinar í ritrýndum tímaritum 2014}

Alexandersson BT, Hreinsson JP, Stefansson T, Jonasson JG, Bjornsson ES. The risk of cancer after an attack of uncomplicated diverticulitis. Scand J Gastroenterology 2014: 49(5); 576-580.

Aradottir M, Reynisdottir ST, Stefansson OA, Jonasson JG, Sverrisdottir A, Tryggvadottir L, Eyfjord JE, Bodvarsdottir SK. Aurora A is a prognostic marker for breast cancer arising in BRCA2 mutation carriers. Jl Pathol: Clin Res 2014: I: 33-40.

Axelsson TA, Hrafnkelsson J, Olafsdottir EJ, Jonasson JG. Tall cell variant of papillary thyroid carcinoma: A population based study in Iceland. Thyroid 2014: Doi: 10.1089/thy.2014.0075.

Baldvinsdottir B, Jonasson JG, Agnarsson UP, Sigurjonsdottir HA. Ectopic Cushing Syndrome Due to Colon Cancer With Dual Morphology. J Endocrinol Metabol 2014; 4(5-6): 153-154.

Cooke SL, Shlien A, Marshall J, Pipinikas CP, Martincorena I, Tubio JMC, ..., ICGC Breast Cancer Group (... Jonasson JGJ ...) et al.. Processed pseudogenes acquired somatically during cancer development. Nature Communications 2014: 5:3644/DOI: 10.1038/ncomms4644.

De Angelis R, Sant M, Coleman MP, Francisci S, Baili P, Pierannunzio D, ...; EUROCARE-5 Working Group (... Jonasson JG, Tryggvadottir LT....). Cancer survival in Europe 1999-2007 by country and age: results of EUROCARE--5-a population-based study. Lancet Oncol. 2014 Jan;15(1):23-34.

de Fine Licht S, Winther JF, Gudmundsdottir T, Holmqvist AS, Bonnesen TG, Asdahl PH, Tryggvadottir L, et al.; on behalf of the ALiCCS study group. Hospital contacts for endocrine disorders in Adult Life after Childhood Cancer in Scandinavia (ALiCCS): a population-based cohort study. Lancet. 2014 Feb 17.

Fallah M, Pukkala E, Sundquist K, Tretli S, Olsen JH, Tryggvadottir L, Hemminki K. Familial melanoma by histology and age: Joint data from five Nordic countries. Eur J Cancer. 2014 Jan 21.

Gatta G, Botta L, Rossi S, Aereleid T, Bielska-Lasota M,Clavel J, Dimitrova N, ... and the Eurocare Working Group (... Jonasson JG, Tryggvadottir LT....). Childhood cancer survival in Europe 1999-2007: results of EUROCARE-5 - a population-based study. Lancet Oncol. 2014; 15: 35-47.

Holmqvist AS, Olsen JH, Andersen KK, Licht SD, Hjorth L, Garwicz S, Moëll C, Anderson H, Wesenberg F, Tryggvadottir L et al.; on behalf of the ALiCCS study group. Adult Life after Childhood Cancer in Scandinavia: Diabetes mellitus following treatment for cancer in childhood. Eur J Cancer. 2014 Feb 4.

Hreinsson JP, Jonasson JG, Bjornsson ES. Bleeding-related symptoms in colorectal cancer: A 4-year nationwide population-based study. Alimentary Pharmacology and Therapeutics 2014: 39(1); 77-84.

Laufey Tryggvadóttir. Saga og próun Krabbameinsfélags Íslands. Læknablaðið 10. tbl. 100. árg. 2014.

Nygård M, Hansen BT, Dillner J, Munk C, Oddsson K, Tryggvadottir L, Hortlund M, Liaw KL, Dasbach EJ, Kjær SK. Targeting human papillomavirus to reduce the burden of cervical, vulvar and vaginal cancer and pre-invasive neoplasia: establishing the baseline for surveillance. PLoS One. 2014 Feb 5;9(2).

Oddsson K, Briem H, Gudmundsdottir Th. National survey among parents or guardians of 12 year old Icelandic girls to assess attitude regarding HPV vaccination and knowledge about cervical cancer. Submitted for publication, Scandinavian Journal of Primary Health Care.

Pukkala E, Martinsen JI, Weiderpass E, Kjaerheim K, Lynge E, Tryggvadottir L, Sparén P, Demers PA. Cancer incidence among firefighters: 45 years of follow-up in five Nordic countries. Occup Environ Med. 2014 Feb 6. doi: 10.1136/oemed-2013-101803. [Epub ahead of print] 
Visser O, Brenner H, Ardanaz E, Bielska-Lasota M, Engholm G, Nennecke A, .., The Eurocare-5 Working Group (... Tryggvadottir L, Jonasson JG....). Cancer survival in Europe 1999-2007 by country and age: results of EUROCARE-5 - a population-based study. Lancet Oncol. 2014; 15: 23-34.

Sant M, Minicozzi P, Mounier M, Anderson LA, De Angelis R, Maynadié M, Monnereau A, MarcosGragera R, Visser $\mathrm{O}$ and the Eurocare Working group (....Jonasson JG.....). Survival increase for major haematological malignancies reflects population effectiveness of novel therapies. 2014; 15: 931-42.

Snaebjornsson P, Coupe VMH, Jonasson L, van Grieken NC, Meijer GA, Jonasson JG. pT4 stage II and III colon cancers carry the worst prognosis in a nationwide survival analysis. Shepherd's local peritoneal involvement revisited. Int J Cancer 2014: 135(2); 467-478.

Stefansson H, Sigurgeirsson B, Olafsson JH, Olafsdottir E, Mooney E, Tryggvadottir L, Jonasson JG. Trends in Breslow's tumour thickness of cutneous melanoma in Iceland 1980-2009. JEADV 2014;29(2):346-52.

Stefansson OA, Moran S, Gomes A, Sayols S. Arribas-Jorba C, Sanoval J, Hilmarsdottir H, Olafsdottir E, Tryggvadottir L, Jonasson JG, Eyfjord JE, Esteller M. A DNA methylation-based definition of biologically distinct breast cancer subtypes. Molecular Oncology 11/2014 DOI: 101016/j.molonc 2014.10012.

Talibov M, Lehtinen-Jacks S, Martinsen JI, Kjærheim K, Lynge E, Sparén P, Tryggvadottir L, Weiderpass E, Kauppinen T, Kyyrönen P, Pukkala E. Occupational exposure to solvents and acute myeloid leukemia: a population-based, case-control study in four Nordic countries. Scand J Work Environ Health. 2014 May 19.

Thorbjarnardottir T, Olafsdottir EJ, Valdimarsdottir UA, Olafsson O, Tryggvadottir L. Oral contraceptives, hormone replacement therapy and breast cancer risk: A cohort study of 16928 women 48 years and older. Acta Oncol. 2014 Jan 24. [Epub ahead of print]

Zanetti R, Schmidtmann I, Sacchetto L, Binder-Foucard F, Bordoni A, .. Tryggvadottir L et al.. Completeness and timeliness: Cancer registries could/should improve their performance. Eur J Cancer. 2014 Jan 3.

\section{Útdrcettir 2014}

Egilsson M, Thoroddsen Ú, Jónasson JG, Ögmundsdóttir MH, Ögmundsdóttir HM. Autophagic pathways and activity in breast and pancreatic cancer. Kynnt á AACR Annual Meeting 2014, haldið í San Diego, Kaliforníu 5.-9. Apríl 2014.

Tryggvadottir L, Olafsdottir, EO, Olafsdottir GH, Alexiusdottir K, Stefansdottir H, Stefansson OA, .., Jonasson JG. Effects of prognostic factors and treatment on survival in BRCA2 mutation carriers. Kynnt á ráðstefnu norrænu krabbameinsskránna (ANCR), haldin í Stokkhólmi, Svípjóð, 2.-4. september 2014.

Laufey Tryggvadóttir. Non-surgical means of risk reduction - What benefit and how acceptable? Issues of chemoprevention. Kynnt á RRS ICELAND, Nordic/Nottingham ORBS Group meeting, 8-9 May 2014, Harpa, Reykjavik. 


\section{Aðalfundur 2014}

Aðalfundur Krabbameinsfélags Íslands var haldinn laugardaginn 10. maí 2014 að Skógarhlíð 8 Reykjavík, í húsnæði Ráðgjafarbjónustunnar 1. hæð. Hann hófst stundvíslega kl. 9:00 að loknum morgunverði. Á fundinn mættu 63 fundarmenn. Jakob Jóhannsson, formaður Krabbameinsfélags Íslands, setti fundinn og bauð gesti velkomna. Lagði hann til að Jóna Valgerður Kristjánsdóttir frá Krabbameinsfélagi Breiðfirðinga yrði fundarstjóri og Sigurður Jón Ólafsson frá Stómasamtökum Íslands fundarritari. Sampykkt með lófataki.

\section{Skýrsla stjórnar fyrir síðastliðið starfsár.}

Jakob Jóhannsson, formaður félagsins, flutti skýrslu stjórnar og greindi frá fyrirhugaðri stofnun vísindasjóðs Krabbameinsfélagsins. Í vörslu félagsins eru nú eignir tveggja minningarsjóða, Kristínarsjóðar og Ingibjargarsjóðar að upphæð 80 milljónir kr. Krabbameinfélag Íslands myndi leggja til 40 milljónir króna en auk pess hafa mörg aðildarfélög ákveðið að leggja málefninu lið. Stofnfé gæti pví orðið um 140 milljónir króna. Styrkir úr pessum vísindasjóði yrðu notaðir til að efla krabbameinsrannsóknir. Krabbameinsskráin tók til starfa fyrir nákvæmlega 60 árum og Leitarstöðin fyrir 50 árum, en pessar tvær starfsdeildir hafa verið ákveðin kjölfesta í starfsemi Krabbameinsfélagsins. Um áramótin urðu pær breytingar, eftir undirritun samnings við heilbrigðisyfirvöld, að allar konur á aldrinum 23-65 ára verði boðaðar í leit vegna leghálskrabbameins á priggja ára fresti. Рað er mikið kappsmál hjá Krabbameinsfélaginu, að leit að krabbameini í ristli verði hafin sem fyrst og hefur margoft verið skorað á heilbrigðisyfirvöld að leggja pví máli lið. Ráðist hefur verið í pað kostnaðarsama verkefni að endurnýja klæðingu á húsinu, ásamt pví að endurnýja pakklæðningu og skipta um alla glugga. Gert er ráð fyrir, að verkinu verði lokið seint í haust. Krabbameinsfélag Íslands og Reykjavíkur hafa haft með sér víðtækt samstarf í hálfa öld, einkum á sviði fræðslu. Samningur milli peirra hefur verið endurnýjaður og stofnað hefur verið sérstakt fræðslu- og fagráð. Að lokum minntist Jakob á öflugt starf Ráðgjafarpjónustunnar, sem færist stöðugt í vöxt. Að lokinni skýrslu bað fundarstjóri leyfis, að fresta frekari umræðu um hana par til undir liðnum önnur mál. Engin andmæli við pví. Fundarfólk kynnti sig. Heiðursráð fyrst, svo stjórn félagsins og síðan einstök aðildarfélög.

\section{Endurskoðaðir reikningar félagsins lagðir fram.}

Sigurður P. Sigmundsson, gjaldkeri stjórnar félagsins gerði grein fyrir reikningum ársins 2013. Peir eru birtir í Ársskýrslu Krabbameinsfélagsins 2013-2014 og vísast til hennar. Kristján Freyr Helgason Stómasamtökunum sagði, að nauðsynlegt hefði verið að fá reikninga fyrr til að hægt væri að glöggva sig á peim. Gagnrýndi hann jafnframt, að peir hefðu mátt vera betur sundurliðaðir. Tók annar fundarmaður undir pessa gagnrýni. Gjaldkeri upplýsti, að stór útgjaldaliður hefði orðið vegna pess að prjú röntgentæki hefðu hrunið og purft endurnýjunar við. Ársreikningar voru pví næst bornir upp og peir sampykktir með öllum greiddum atkvæðum.

\section{Skýrslur aðildarfélaga.}

Fundarstjóri vísaði til ársskýrslunnar par sem skýrslur aðildarfélaganna eru birtar.

\section{Stjórnarkjör.}

Uppstillingarnefnd lagði til að Jakob Jóhannsson yrði endurkjörinn formaður til næstu tveggja ára. Tillagan var sampykkt með lófataki. Tillaga kom fram um að eftirtaldir yrðu kosnir meðstjórnendur til næstu tveggja ára: Jón Dorkelsson, viðskiptafræðingur og formaður Stómasamtaka Íslands, Sigurður P. Sigmundsson, viðskiptafræðingur, og Stefán Eiríksson, lögreglustjóri. Tillagan sambykkt með lófataki. Tillaga kom fram um að Árni Einarsson, uppeldisfræðingur og varaformaður Krabbameinsfélags Reykjavíkur yrði kosinn í stjórn til eins ár í stað Agnesar Smáradóttur, sem er á förum til útlanda. Tillagan sampykkt með lófataki. Fyrir í stjórn eru Friðrik Vagn Guðjónsson og Hulda Bjarnadóttir. Tillaga um að Hinrik Greipsson, stjórnarmaður í Framför, og Steinunn Eva Dórðardóttir, stjórnarmaður í Krabbameinsfélagi Akraness og nágrennis yrðu kjörin varamenn í stjórn til eins árs. Sampykkt með lófataki. 


\section{Kosnir tveir endurskoðendur (skoðunarmenn) og einn til vara.}

Gerð var eftirfarandi tillaga um félagskjörna endurskoðendur til eins árs: Birna Guðmundsdóttir, stjórnarmaður í Krabbameinsfélagi Reykjavíkur, Ragnheiður Guðmundsdóttir, stjórnarmaður í Samhjálp kvenna, og Jón Auðunn Jónsson, stjórnarmaður í Krabbameinsfélagi Hafnarfjarðar til vara. Tillagan sampykkt með lófataki.

\section{Kosning í uppstillinganefnd.}

Nefndin er kosin til eins ár í senn. Í nefndinni núna eru Almar Grímsson, Álfheiður Hjaltadóttir, Ásta Hallgrímsdóttir, Guðrún Sigurjónsdóttir og Pórarinn Sveinsson. Almar og Ásta hafa verið í nefndinni í fjögur ár og eru pví ekki kjörgeng lengur. Álfheiður, Guðrún og Dórarinn gefa kost á sér áfram. Í stað hinna var stungið uppá Nönnu Friðriksdóttur og Póru Hrönn Njálsdóttur. Pessi tillaga var sampykkt með lófataki.

\section{7. Önnur mál.}

Hafrún Dóra Júlíusdóttir, Krabbameinsfélagi Hafnarfjarðar, benti á, að í stjórn Krabbameinsfélags Íslands væri aðeins ein kona af sjö. Á móti benti Stefanía Gísladóttir, Krabbameinsfélagi Norðausturland, á að uppstillinganefnd væri á hinn bóginn mjög kvenlæg.

Guðmundur Björnsson, formaður Krabbameinsfélags Suðurnesja, kynnti pá ákvörðun félagsins að styrkja fyrirhugaðan vísindasjóð með 500 púsund króna fjárframlagi. Hvað hann pennan sjóð lofa góðu um rannsóknir í framtíðinni. Hann ræddi einnig um velunnarakerfið.

Steinunn Eva Pórðardóttir, stjórnarmaður í Krabbameinsfélagi Akraness og nágrennis, skýrði frá netkönnun meðal stjórna aðildarfélaganna. 30 svör bárust, par af 23 frá formönnum félaga. Niðurstaðan var almenn ánægja með samstarfið við Krabbameinsfélag Íslands.

Stefán Eiríksson í stjórn Krabbameinsfélagi Íslands pakkaði pað traust, sem fundarmenn hefðu sýnt sér og öðrum með pví að kjósa pá í stjórnina. Hann kvað petta starf vera bæði frábært og öflugt. Nauðsynlegt væri að viðhalda pví trausti, sem félagar um allt land bæru til stjórnar félagsins. Hann hrósaði Ráðgjafarpjónustunni fyrir frábært starf. Rannsóknarvinnan í húsinu skiptir máli enda hefðum við margt gott til alpjóðafræðafélagsins að leggja. Skýrði hann pví næst frá stofnun nýs vísindasjóðs, en hugmyndin með honum er að elfa vísindastarfið með pví að sameina alla fjármuni undir einn hatt. •að skiptir máli, að öll aðildarfélögin komi að pessum sjóði, en sjálft fjárframlagið væri aukaatriði. Aðrir byrftu að koma að pessum sjóði, fyrirtæki sem einstaklingar. Dyrftum að ná eyrum fjöldans og kynna samfélagslega ábyrgð styrktaraðila. Stofnskrá vísindasjóðsins er í smíðum og verður hann væntanlega formlega stofnaður í haust.

Ester Porvaldsdóttir, formaður Krabbameinsfélags Suðausturlands, afhendi gjafabréf að upphæð 500 púsund krónur til styrktar fyrirhuguðum vísindasjóði.

Sigurður P. Sigmundsson, gjaldkeri, sagði að í velunnarasjóðnum væru nú 18 milljónir króna en fáir hefðu sótt um styrk í fyrra.

Ester Ólafsdóttir, formaður Krabbavarnar Vestmannaeyjum, afhenti fyrir hönd félagsins 500 púsund krónur til starfsemi íbúðanna á vegum Krabbameinsfélags Íslands. Afhenti hún jafnframt fallega mynda af Vestmannaeyjum, sem tekin var á bleikum októbermánuði í fyrra. Hún ræddi m.a. um bið eftir húsnæði hjá íbúðum á vegum Krabbameinsfélagsins, sem henni fannst í sumum tilfellum of löng.

Guðlaug B. Guðjónsdóttir, framkvæmastjóri Krabbameinsfélags Reykjavíkur, og Gunnar Már Hauksson, gjaldkeri pess félags, sögðu að velunnarakerfið hefði skilað aðildarfélögunum fáum nýjum félögum. Fjáröflunarráð á að vera til mikils gagns sem milliliður milli félaga, en starfskraftar pess ekki nýttir sem skyldi. раð parf аð kortleggja velunnara eftir svæðum. Guðlaug kynnti vörur fyrir haustsölu aðildarfélaganna, en pað eru spilastokkur, málband og pessi hefðbundni penni. Hvert félag hefur annars rétt á að selja pað sem pað vill. Guðlaug sagði frá nýrri fræðslumynd, um reykingatengda lungnasjúkdóma, sem var frumsýnd sl. haust, en myndin er gerð í samvinnu við Samtök lungnasjúklinga. 
Agnes Smáradóttir, formaður Krabbameinsfélags Reykjavíkur, sagði frá peirri ákvörðun félagsins að gerast stofnfélagi að vísindasjóðnum. Nauðsynlegt að félagið verði skráð á spjöld sögunnar með pessum hætti. Lagði hún pví næst fram prjár ályktunar fyrir hönd stjórnar Krabbameinsfélags Reykjavíkur:

Ályktun um ristilkrabbamein. Aðalfundur Krabbameinsfélags Íslands, haldinn 10. maí 2014, áréttar áskorun tólf fagfélaga og sjúklingahópa, par sem skorað var á stjórnvöld að hefja hópleit að ristilkrabbameini strax og hvetur til pess að nú pegar verði undirbúningur hafinn og sett verði upp markaðs- og aðgerðaráætlun par að lútandi.

Ályktun um tóbaksvarnir I. Aðalfundur Krabbameinsfélags Íslands, haldinn 10. maí 2014, fagnar peim árangri sem náðst hefur í tóbaksvörnum. Hann er ekki síst tilkominn vegna fyrirbyggjandi aðgerða krabbameinsfélaganna. Mikilvægt er að vera áfram vel vakandi yfir stöðu tóbaksvarna og hvetja til markvissra aðgerða til að hindra að fólk noti tóbak, í hvaða formi sem er, eða verði fyrir óbeinum reykingum. Sérstaklega er mikilvægt að vernda börn og ungmenni.

Ályktun um tóbaksvarnir II. Aðalfundur Krabbameinsfélags Íslands, haldinn 10. maí 2014, hvetur stjórnvöld til að breyta tóbaksvarnalögum og reglugerðum pegar í stað, pannig að notkun, sala og markaðssetning á rafsígarettum (e-sígarettum) falli á sama hátt undir lögin og annar tóbaksvarningur.

Ofangreindar ályktanir voru sampykktar með öllum greiddum atkvæðum.

Sigurður Björnsson, fyrrum formaður Krabbameinafélags Íslands, fjallaði um forvarnir vegna reykinga fyrr og nú. Lýðheilsustöð átti að taka við pessu starfi krabbameinsfélaganna, en par vantaði greinilega pann neista og áhuga, sem ríkti hjá sjálfboðaliðum. Fagnaði hann fram komnum ályktunum, sem hann hefði stutt heilshugar. Rafsígarettur væru ekkert annað en dulbúinn áróður.

Kristján Freyr Helgason, Stómasamtökunum, pakkaði fyrir góðar umræður. Vildi hann leggja áherslu á jafnvægið milli vísindastarfs Krabbameinsfélags Íslands annars vegar og stuðning við sjúklinga hins vegar, pannig að hvorugur biði skarðan hlut.

Alfreð Steinar Rafnsson, formaður Krabbameinsfélags Austurlands, tók undir gagnrýni Guðmundar á velunnarakerfið. Sagði hann kerfið bitna sérstaklega á félögum út á landi og pá ekki síst peim, er búa í strjálbýli. Upplýsingastreymið er alls ekki nógu gott. Petta parf að taka betur upp á næsta formannafundi.

Ragnheiður Haraldsdóttir hjúkrunarfræðingur, forstjóri Krabbameinsfélags Íslands, hafði orðið að lokum. Hún sagði, að petta hefði verið ánægjulegur og fróðlegur aðalfundur. Fór hún yfir helstu atriði, sem fram hefðu komið. Síðastliðið ár hefur verið árangursríkt að mörgu leyti einsog fram kemur í ársskýrslunni. Skemmdirnar á húsnæðinu hefðu á hinn bóginn verið meiri, en gert hafði verið ráð fyrir. Á aðalfundarauka, daginn áður, hefði komið fram áhersla á leitarstarf. Ánægjulegt hve margir ætla að leggja fyrirhuguðum vísindasjóði lið, en enn er hægt að leggja inn tillögur að breytingum á honum. Hún tók undir gagnrýni Kristjáns Freys pess efnis, að nauðsynlegt sé að senda út ársskýrslu og reikninga sérstaklega með viku fyrirvara. Mikilvægt er að fá pessa upplýsingar í hendur fyrr. Ragnheiður er sammála peirri skoðun, að jafnvægi parf að vera milli Krabbameinsfélags Íslands og aðildarfélaganna hins vegar og rannsóknastarfsins í húsinu annars vegar. Tók hún sem dæmi, að krabbameinsfélagið í Svípjóð væri í ríkari mæli að færa sig yfir á svið sjúklinganna. Við purfum að styðja við leitarstarfið og rannsóknir, sem og fræðslu og forvarnir og ekki síst starf Ráðgjafarpjónustunnar. Hún kvaðst vera ánægð með könnun Steinunnar Evu; hélt satt að segja, að starfsfólk og stjórn félagsins myndi fá verri útreið. Við purfum að leggja meiri áherslu á óformlegt spjall með heimsóknum til aðildarfélaganna. Hún sagði að pað sem fram hefði komið á pessum fundi væri gott veganesti fyrir næsta formannafund, sem yrði frekari vettvangur umræðna. Ef til vill hafa stór verkefni eins og bleiki mánuðurinn lamandi áhrif á sum smærri félög, en nauðsynlegt er að vinna betur með peim. Markaðsdeildin er ávallt reiðubúin í samstarf við aðildarfélögin. Að lokum vék hún að velunnarakerfinu. Đað eru ýmsir vankantar á kerfinu, sem er ekki enn búið að taka út sinn proska.

Jakob Jóhannsson, formaður félagsins, sleit fundi kl. 11:45. Síðan var hádegisverður í Perlunni.

Sigurður Jón Ólafsson. 


\section{Formannafundur 2014}

Formannafundur Krabbameinsfélagsins var haldinn á Akureyri laugardaginn 4. október 2014 og hófst kl. 10:00. Friðrik Vagn Guðjónsson varaformaður Krabbameinsfélags Akureyrar og nágrennis setti fundinn. Jakob Jóhannesson formaður Krabbameinsfélags Íslands ávarpaði fundarmenn og stakk upp á Friðriki Vagni sem fundastjóra og Stefaníu Gísladóttur sem ritara. Dátttakendur voru 28 frá 18 félögum.

Ragnheiður Haraldsdóttir forstjóri Krabbameinsfélags Íslands sagði frá starfsemi félagsins. Hín minnist meðal annars á að unnið væri að viðhaldi húss félagsins, erfiðlega gengi að fá lækna til starfa við krabbameinsleit í brjóstum og vefsíðan væri í endurkoðunn. Hún taldi innra starf félagsins gott og að unnið hefði verið að ýmsum skýrslum sem yrðu lagðar fyrir fundinn og að nauðsynlegt væri að auka fjármagn til krabbameinsrannsókna og væri verið að safna fé frá aðildarfélögunum í nýjan vísindasjóð.

Brynja Björk Gunnarsdóttir frá Samhjálp kvenna kynnti nýtt nafn á félagið, Brjóstaheill - Samhjálp kvenna.

Atli Már Sveinsson íprótta- og heilsufræðingur kynnti skýrslu um endurhæfingu eftir greiningu krabbameins, sem hann vann fyrir Krabbameinsfélagið, en hann sérhæfði sig í pjálfun krabbameinsveikra við University of Northen Colorado. Síðan var rætt um skýrsluna, nauðsyn samhæfingar og skilgreinar á pörf fyrir endurhæfingu. Friðrik gat pess að á Kristnesi væru pláss fyrir krabbameinssjúka.

Gunnjóna Una Guðmundsdóttir félagsráðgjafi kynnti handbók sína með hagnýtum upplýsingum fyrir sjúklinga og lagði áherslu á að fólk pyrfti að kanna réttindi sín. Hún sagði að jafningjastuðningur hefði skilað mjög góðum árangri.

Sigurður P. Sigmundsson gjaldkeri stjórnar Krabbameinsfélags Íslands ræddi um reynslu af styrkjum úr velunnarasjóði félagsins og fór yfir skýrslu um velunnarakerfið. Hann sagði nauðsynlegt að halda vel utan um kerfið vegna pess að pað skipti starfsemi félagsins miklu máli. Anna Borg Harðardóttir frá Krabbameinsfélagi Hafnarfjarðar fjallaði um átak gegn munntóbaksnotkun, Gunnar Már Hauksson frá Krabbameinsfélagi Reykjavíkur fagnaði pví hvernig velunnarakerfið hefði próast og fleiri tóku til máls.

Umræður héldu áfram að loknum hádegisverði.

Alfreð Steinar Böðvarsson frá Krabbameinsfélagi Austurlands sagði velunnarakerfið gefa ýmsa möguleika en sníða pyrfti af pví vankanta.

Guðmundur Björnsson frá Krabbameinsfélagi Suðurnesja fór yfir umræður um kerfið og reglur um sjóðinn, allt síðan á aðalfundi 2012. Hann taldi margt skýrast með skýrslunni sem lögð hefði verið fram en setja pyrfti í fastari skorður hvenær upplýsingar til aðildarfélaga væru unnar, hvenær framlag fyrir nýja félagsmenn væri greitt o.fl.

Ragnheiður Haraldsdóttir pakkaði Guðmundi fyrir athugasemdirnar og sagði að samið hefði verið við Miðlun um að halda utan um kerfið.

Stefanía Gísladóttir frá Krabbameinsfélagi Norðausturlands lagði til að svæðafélög sem væru ekki með launaða starfsmenn gætu sótt um styrk fyrir hluta af ferðakostnaði á formannafundi og aðalfundi.

Sigurður P. Sigmundsson sagði orðið erfiðara en áður að fá fólk til að starfa í félögum og fór yfir félagafjölda aðildafélaganna frá 1989 til 2014. Samkvæmt pví hefur velunnarakerfið ekki neikvæð áhrif á aðildafélögin. Fleiri tóku til máls og tjáðu sig um velunnarakerfið.

Halldóra B. Sævarsdóttir textilkennari kynnti meistararitgerð sína: Listsköpun kveikir lífsneista. Ritgerðin fjallar um rannsókn á áhrifum listsköpunar í endurpjálfun og nauðsyn pess að virkja sköpunargáfuna.

Sigrún Jónsdóttir sjúkrapjálfari sagði frá starfi sínu fyrir Krabbameinsfélag Akureyrar og nágrennis og taldi nauðsynlegt að próa endurhæfingu fyrir krabbameinssjúka og að slökun og öndun væri nauðsynleg fyrir krabbameinssjúklinga eins og aðra. 
Stefanía Gísladóttir fagnaði fréttum um að vonir stæðu til að sjúkrahótel tæki til starfa á Akureyri árið 2015. Fundarmenn lýstu ánægju með pessa próun.

Salvör Sæmundsdóttir frá Krafti sagði frá styrktartónleikum í Hörpu til stuðnings ungu fólki sem hefur greinst með krabbamein.

María Reykdal frá Krabbameinsfélagi Skagafjarðar sagði frá pví að félagið hefði safnað einni milljón króna með áheitadagskrá, sagði frá fundi Kiwanis um ristilkrabbamein og áformum um að bjóða körlum í ristilskoðun. María bauð til næsta formannafundar í Skagafirði haustið 2015.

Friðrik Vagn Guðjónsson pakkaði fundarmönnum fyrir pátttökuna og góðar umræður og Jakob Jóhannsson sleit fundi um kl. 16.

Stefanía Gísladóttir. 


\section{Aðildarfélög Krabbameinsfélags Íslands}

Svæðafélög:

Krabbameinsfélag Reykjavíkur

8. 3. 1949

1.035

Krabbameinsfélag Akraness og nágrennis

9. 2. 1969

300

Krabbameinsfélag Borgarfjarðar

14. 2. 1970

300

Krabbameinsfélag Snæfellsness (og Von)

27. 9. 2005

85

Krabbameinsfélag Breiðfirðinga

Krabbameinsfélag Tálknafjarðar og Vesturbyggðar

19. 10. 2005

30.11. 1970

Krabbameinsfélagið Sigurvon (og Vinir í von)

4. 11.2001

75

Krabbameinsfélag Hvammstangalæknishéraðs

13. 10.1968

300

Krabbameinsfélag Austur-Húnavatnssýslu (og Samhugur)

2. 11.1968

70

Krabbameinsfélag Skagafjarðar (og Dugur)

Krabbameinsfélag Akureyrar og nágrennis (og Norðankraftur)

12. 6.1966

200

21. 11. 1952

Krabbameinsfélag Suður-Dingeyinga (og Birta)

28. 8. 1968

420

1.360

Krabbameinsfélag Norðausturlands

Krabbameinsfélag Austurlands (og stuðningshópur)

18. 8.1970

400

20. 4. 1970

85

Krabbameinsfélag Austfjarða (og stuðningshópur)

21. 4. 1970

155

Krabbameinsfélag Suðausturlands

21. 4. 1970

480

Krabbameinsfélag Vestur-Skaftafellssýslu

Krabbameinsfélag Rangárvallasýslu

Krabbameinsfélag Árnessýslu (og Bandið)

6. 5.1971

150

7. 5. 1971

Krabbavörn Vestmannaeyjum (og Eyjarós)

29. 5. 1971

30

25. 4. 1949

105

Krabbameinsfélag Suðurnesja (og Sunnan 5)

15. 11.1953

Krabbameinsfélag Hafnarfjarðar

10. 4. 1949

300

250

915

480

Stuðningshópar:

Brjóstaheill - Samhjálp kvenna

1979

350

Framför

12. 2. 2007

25

Kraftur

1.10. 1999

510

Ný rödd

20.12. 1980

20

Ristilfélagið

Stómasamtök Íslands

30. 6. 2009

65

16. 10.1980

300

Styrkur

20.10. 1987

350

Hópar sem starfa með Krabbameinsfélagi Reykjavíkur (á landsvísu):

Góðir hálsar (stuðningshópur um blöðruhálskirtilskrabbamein)

6. 12. 2000

125

Stuðningshópur kvenna með eggjastokkakrabbamein

27. 2. 2002

20

Hópar sem starfa með Ráðgjafarpjónustu Krabbameinsfélagsins (á landsvísu):

Lungnahópurinn

17.11. 2011

Carcinoid-hópurinn

5. 2. 2013

Frískir menn (virkt eftirlit)

20. 3.2014 


\section{Krabbameinsfélag Reykjavíkur}

Stofnað: 8. mars 1949. Félagsmenn: 1.035 (par af 70 ævifélagar).

Skrifstofa: Skógarhlíð 8, Reykjavík. Póstfang: Pósthólf 5420, 125 Reykjavík.

Sími: 540 1900. Fax: 540 1910. Vefsíða: www.krabb.is/reykjavik

Framkvæmdastjóri: Guðlaug B. Guðjónsdóttir (gbg@krabb.is).

Stjórn kosin á aðalfundi 23. mars 2015:

Formaður: $\quad$ Árni Einarsson, Eiðistorgi 3, 170 Seltjarnarnesi

Varaformaður: Ásgerður Sverrisdóttir, Viðarrima 35, 112 Reykjavík

Gjaldkeri: $\quad$ Gunnar Már Hauksson, Kópavogstúni 4, 200 Kópavogi

Ritari: $\quad$ Birna Guðmundsdóttir, Suðurhvammi 1, 220 Hafnarfirði

Meðstjórnandi: Arnar Hauksson, Selvogsgrunni 20, 104 Reykjavík

Meðstjórnandi: Guðrún Sigurðardóttir, Grenimel 46, 107 Reykjavík

Meðstjórnandi: Dórunn Sævarsdóttir, Lönguhlíð 25, 105 Reykjavík

Varamenn: Jón L. Árnason, Skúli Jón Sigurðarsson og Vala Smáradóttir.

5611208 arni@forvarnir.is

\section{Starfsemi 2014-2015}

Skýrslan nær yfir síðasta starfsár, frá aðalfundi 17. mars 2014, til aðalfundar 23. mars 2015. Stjórnarfundir voru níu milli aðalfunda og sóttu varamenn pá til jafns við aðalmenn. Ársskýrsla í fullri lengd er á: http://www.krabb.is/Thjonusta/Svaedafelog/krabbameinsfelag-reykjavikur

\section{Fræðslu- og forvarnastarfsemi}

Í samstarfssamningi við Krabbameinsfélag Íslands frá pví í mars 2014 er kveðið á um fræðslu- og fagráð sem skuli skipað fimm manns og tveimur til vara. prír aðalmenn eru tilnefndir af Krabbameinsfélagi Íslands og tveim frá Krabbameinsfélag Reykjavíkur. Framkvæmdastjóri Krabbameinsfélags Reykjavíkur er starfsmaður ráðsins. Hlutverk ráðsins er að marka stefnu í fræðslumálum Krabbameinsfélagsins og leggja fram framkvæmda- og kostnaðaráætlun, par sem gerðar eru tillögur um helstu verkefni komandi árs.

\section{Útgáfumál}

Fræðsluritið „Mergæxli“ var gefið út og fræðsluritið „Krabbamein í ristli og endaparmi“ var endurgert. Fræðsluspjaldið „Skilaboð til karla“ var endurprentað. Fræðsluefnið „Taugainnkirtlaæxli“, sem unnið var í samstarfi við Ráðgjafarpjónustuna, er á vef Krabbameinsfélagsins. „Spurningar og svör um krabbamein“, sem einnig er vefsíðuefni, var endurgert. Búið er að prenta annan ársskammt af afmæliskortunum til fimmtugra, „Gefðu pér góða afmælisgjöf“, aðeins lagfært frá fyrra ári.

\section{Frœðslumyndir}

Fræðslumyndin „,Aðgát í nærveru sólar“ sem er um sortuæxli og önnur húðkrabbamein var sýnd í tvígang á ríkissjónvarpinu í júní sl. Einnig var útbúin netútgáfa með enskum texta. Myndin var unnin í samstarfi við átakshóp um sólarvarnir; Geislavarnir ríkisins, Embætti landlæknis og húðlæknana Bárð Sigurgeirsson og Jón Hjaltalín Ólafsson sem voru faglegir ráðgjafar við gerð myndarinnar. •að er Páll Kristinn Pálsson kvikmyndagerðarmaður sem gerði myndina með okkur.

\section{Tóbaksvarnir}

Krabbameinsfélag Reykjavíkur hefur haldið reglulega reykleysisnámskeið par sem pátttakendur hittast átta sinnum á priggja mánaða tímabili og að námskeiði loknu er pátttakendum fylgt eftir í eitt ár. Á starfsárinu voru haldin prjú reykleysissnámskeið, að auki voru nokkrir í einstaklingsráðgjöf. Leiðbeinandi á námskeiðinu og í einstaklingsráðgjöfinni er Ingibjörg K. Stefánsdóttir hjúkrunarfræðingur. Ingibjörg svarar fyrirspurnum um tóbaksvarnir sem koma gegnum vefinn og í síma. Einnig hefur hún svarað fyrirspurnum frá foreldrum og gefið ábendingar og veitt ráðgjöf um pað hvernig takast á á við tóbaksnotkun barna og unglinga. 
Ingibjörg var með ráðgefandi erindi hjá Starfsendurhæfingu á Selfossi. Úttgerðarfyrirtækið Skinneypinganes á Höfn í Hornafirði leitaði til félagsins með ósk um aðstoð vegna reykleysisnámskeiðs. Haft var samband við formann Krabbameinsfélags Suðausturlands sem tók að sér að halda námskeiðið með námskeiðsefni og leiðbeiningum Ingibjargar. Krabbameinsfélag Reykjavíkur mun kynna pennan möguleika fyrir aðildarfélögum Krabbameinsfélagsins. Mikilvægt er að efla meðferð til reykleysis par sem reykingar eru stærsti áhættupáttur krabbameins. Félagið hefur áhuga á að sett verði á laggirnar pjónustumiðstöð í tóbaksvörnum. Ingibjörg hefur tekið að sér að svara árlegum spurningalista frá Alpjóðaheilbrigðismálastofnuninni (WHO) um ýmislegt er snýr að tóbaksvörnum á Ísland. Guðlaug var í vetur skipuð í fagráð landlæknis um tóbaksvarnir. Guðlaug sótti albjóðlega ráðstefnu um tóbaksvarnir sem haldin var í Istanbul í mars 2014 (6th European Conference on Tobacco or Health). Á pessari ráðstefnu er kynnt staða Evrópuríka í tóbaksvörnum en par var Ísland í priðja sæti varðandi stöðuna í Evrópu (The Tobacco Control Scale 2013).

\section{Hættan er ljós og samnorrænt átak}

Ellefu ár eru síðan átaksverkefnið „Hættan er ljós“ hófst en pað er samstarfsverkefni Geislavarna ríkisins, Embætti landlæknis, húðlækna og Krabbameinsfélagsins. Stefna hópsins er að stuðla að skynsamlegri hegðun landsmanna í sól og að draga enn frekar úr almennri notkun ljósabekkja. Árlega er gerð könnun átakshópsins á ljósabekkjanotkun landsmanna og haldið verður áfram að fræða um afleiðingar óhóflegra sólbaða. Niðurstöður síðustu könnunar staðfesta minnkandi notkun ljósabekkja hér á landi og að fáir undir 18 ára aldri nota ljósabekki. Samkvæmt talningu Geislavarna ríkisins á fjölda ljósabekkja hefur ljósabekkjum fækkað mjög mikið í Reykjavík. Guðlaug er fulltrúi Krabbameinsfélagsins í norrænu samstarfi um varnir gegn húðkrabbameini. Norræna samstarfið felst í pví að fá ferðapjónustuna, ferðaskrifstofur, flugfélög og fleiri, í samvinnu um að bæta upplýsingar um öryggi í sólinni og hvernig skynsamlegt er að njóta sólarinnar á sem öruggastan hátt. Einnig hefur hópurinn með sér samstarf um fleira er viðkemur sólarvörnum.

\section{Bleiki mánuðurinn}

Í bleika mánuðinum var aðstoðað við yfirlestur gagna og setnir samráðsfundir.

Krabbameinsfélag Reykjavíkur, Krabbameinsfélag Hafnarfjarðar, Brjóstaheill - Samhjálp kvenna og Ráðgjafarpjónusta Krabbameinsfélagsins stóðu fyrir málpingi um heilbrigðispjónustu við krabbameinssjúklinga í október undir yfirskriftinni „Er besta pjónusta í boði“. Góð fjölmiðlaumræða varð í tengslum við málpingið og fyrirkomulag pingsins með frummælendum og pallborðsumræðum kom vel út.

\section{Mottumars}

Framkvæmdastjóri hefur setið samráð- og undirbúningsfundi og aðstoðað með yfirlestur á greinum og við að útbúa ýmiss konar fræðslu- og upplýsingagögn. Áherslan í mánuðinum petta árið var á ristilkrabbamein. Aðstoðað var við örráðstefnu um karla og krabbamein par sem Ásgerður Sverrisdóttir krabbameinslæknir og varaformaður Krabbameinsfélags Reykjavíkur var með erindi. Hún tók líka pátt í fjölmiðaumfjöllun í mánuðinum. Einnig var samvinna við skipulagningu opins húss hjá stuðningshópum Krabbameinsfélagsins.

\section{Nemendur og skólar}

Ætíð er nokkuð um að starfsfólk félagsins aðstoði nemendur og kennara framhaldsskóla og háskóla við heimildaöflun vegna ýmissa skrifa, rannsókna og kennslu sem tengist krabbameini og forvörnum.

\section{Varnir gegn notkun áfengis og vímuefna}

Stjórn Krabbameinsfélag Reykjavíkur sampykkti ályktun í október sl. vegna frumvarps um breytingar á lögum um verslun með áfengi og tóbak. Stjórnin leggst eindregið gegn frumvarpinu par sem lagt er til að einkaleyfi Áfengis- og tóbaksverslunar ríkisins á smásölu áfengis verði afnumið og að smásala áfengis verði gefin frjáls. Alpingismenn voru hvattir til að fella frumvarpið. Ályktunin var send pingmönnum í velferðarnefnd og allsherjar- og menntamálanefnd.

Krabbameinsfélag Reykjavíkur er pátttakandi í „Viku 43“ sem er vettvangur félagasamtaka sem vilja leggja forvörnum lið og/eða hafa forvarnir að markmiði starfs síns, til pess að vekja athygli á forvarnastarfi og 
áfengis- og vímuefnamálum. Í „Viku 43“ var að pessu sinni kastljósinu beint að ýmsu er varðar forvarnir meðal barna og ungmenna. Áhersla var lögð á lífsstíl og sjálfsmynd og vakin athygli á pví góða starfi með ungu fólki sem lýtur að lífsstíl og félagsstarfi í nærsamfélaginu (heimabyggð). Félagið er einnig pátttakandi í átakinu „Verum vakandi“ sem er vakningarátak sömu aðila og standa að Viku 43 og snýr að skaðsemi kannabis undir yfirskriftinni „Bara gras?“. Umsjón með pessum verkefnum hefur Samstarfsráð um forvarnir sem um 25 samtök standa að. Guðlaug er fulltrúi Krabbameinsfélagsins í stjórn ráðsins. Samstarfsráðið ályktaði um og sendi áskorun til alpingismanna par sem pað mótmælti frumvarpi um að fella úr gildi einkaleyfi Áfengis- og tóbaksverslunar ríkisins og gefa smásölu áfengis frjálsa upp að ákveðnu marki. Ráðið skipulagði greinaskrif og umræðu á samfélagsmiðlum.

\section{Vefsíðumál}

Krabbameinsfélag Reykjavíkur stofnaði eigin Facebook-síðu í haust. Vala Smárdóttir varamaður í stjórn útbjó stefnumarkandi plagg um stefnu félagsins í notkun á Facebook.

\section{Stuðningur við sjúklinga}

Tveir stuðningshópar sem eru ekki formlegir aðilar að Krabbameinsfélagi Îslands starfa undir verndarvæng Krabbameinsfélags Reykjavíkur. Annars vegar eru pað Góðir hálsar, stuðningshópur um krabbamein í blöðruhálskirtli, og hins vegar Stuðningshópur kvenna með krabbamein í eggjastokkum. Hvor hópur um sig hittist reglulega á rabbfundum og fræðslufundum, karlahópurinn fyrsta miðvikudag í mánuði allt árið og kvennahópurinn síðasta miðvikudag í hverjum mánuði á veturna. Góðir hálsar tóku pátt í verkefninu „Karlarnir og kúlurnar“ par sem hópur karla fékk tækifæri til að æfa golfsveifluna og fræðast gildi jafningjastuðnings. Félagar í Góðum hálsum hafa verið öflugir við að veita stuðning við nýgreinda pegar eftir pví hefur verið leitað. Á næstunni verður Stuðningshópi kvenna með krabbamein í eggjastokkum breytt pannig að fleiri krabbamein tengd grindarholslíffærum kvenna falli undir einn og sama stuðningshópinn. Báðir hóparnir hafa tekið pátt í samstarfsfundum stuðningshópanna sem Ráðgjafarbjónustan boðar til. peir voru einnig pátttakendur í opnu húsi stuðningshópanna núna í mars sem var haldið til að kynna pað góða og mikilvæga starf sem unnið er í stuðningshópunum.

Krabbameinsfélag Reykjavíkur, Ristilfélagið og Stómastamtökin hafa haldið áfram með samstarf ásamt meltingarsérfræðingi, krabbameinslækni og fleirum stuðningsaðilum í árveknihópi um ristilkrabbamein. Í mars í fyrra var byrjað að senda afmæliskort til peirra sem urðu fimmtugir á árinu, „Gefðu pér góða afmælisgjöf“, með skilaboðum um mikilvægi pess að gefa sjálfum sér pá gjöf að fara í ristilskoðun. Ákveðið var að halda pessu verkefni áfram par sem bæði Ráðgjafarpjónustan og læknar staðfestu að útsending kortanna skilaði árangri t.d. með auknum fyrirspurnum.

Stuðningshópurinn Ristilfélagið hefur átt erfitt uppdráttar undanfarin ár af ýmsum ástæðum og lítil starfsemi verið hjá félaginu. Árveknihópurinn setti sér pað að markmiði að endurvekja félagið og núna í upphafi mars var haldinn aðalfundur, sá fyrsti síðan 2010, og ný stjórn kosinn.

Félagið er í góðu samstarfi við stuðningshópa Krabbameinsfélagsins og aðstoðar pá eftir pörfum, t.d. við gerð fræðsluefnis, árskýrslna, yfirlestur, við skipulag funda og fleira.

\section{Styrkveitingar}

Styrkveitingar félagsins á reikningsárinu voru sjö, að fjárhæð rúmar 400.000 króna.

\section{Happdrcettið}

Happdrætti Krabbameinsfélagsins hefur verið ein helsta tekjulind Krabbameinsfélags Reykjavíkur í sextíu ár og hefur gegnum árin gert félaginu kleift að sinna fræðslustarfinu. Баð má segja að fræðsla um krabbamein og krabbameinsvarnir byggist að miklu leyti á happdrættisfé og að happdrættið eigi sinn pátt í peim mikla árangri sem náðst hefur í tóbaksvörnum síðustu áratugi. Heildarsala happdrættismiða í bæði sumar- og jólahappdrætti varð heldur betri en árið áður og vinningshlutfall varð lægra. Í samstarfssamningi Krabbameinsfélags Reykjavíkur og Krabbameinsfélags Íslands er ákvæði um stjórn happdrættis Krabbameinsfélagsins. Í stjórn happdrættisins eru tveir fulltrúar hvors félags, par af báðir gjaldkerar peirra. 
Hlutverk stjórnar happdrættisins er að ákvarða hvernig skipting allra tekna happdrættisins verði. Jafnframt að hafa eftirlit með rekstri og reikningsskilum happdrættisins.

\section{Fjármál}

Afkoma félagsins á reikningsárinu var neikvæð um tæpar 2,6 milljónir króna. Reiknaðar lífeyrissjóðsskuldbindingar félagsins eru rúmar 50,4 milljónir króna og hækkuðu um rúmar 3,3 milljónir króna milli ára. Kostnaður við fræðslustarfsemi félagsins var tæpar 18,3 milljónir króna. Árið 2014 skilaði happdrættið félaginu um 18,4 milljónum króna í tekjur en bær voru árið áður um 15,3 milljónir króna. Dessar upphæðir eru fyrir utan lífeyrisskuldbindingar og greiddan lífeyri. Aðrir tekjuliðir, fyrir utan vaxtatekjur, eru félagsgjöld, merkjasala, styrkir og námskeiðsgjöld. Merkjasalan var fyrstu helgina í september. Seldir voru pennar, málbönd og spil með merki Krabbameinsfélagsins.

Samstarf við ýmsa aðila

Aðalfundur Krabbameinsfélags Íslands var haldinn í maí 2014. Á fundinum lagði stjórn Krabbameinsfélag Reykjavík fram prjár ályktanir sem allar voru sampykktar: Áskorun til stjórnvalda um að hefja pegar hópleit að ristilkrabbameini, ályktun um mikilvægi markvissra aðgerða stjórnvalda varðandi tóbaksvarnir, ekki síst pær er snúa að börnum og ungmennum, og sú priðja var ályktun um að stjórnvöld breyti tóbaksvarnalögum og reglugerðum svo rafsígarettur falli undir lögin á sama hátt og annar tóbaksvarningur.

Formannafundur Krabbameinsfélaganna var haldinn í október 2014 á Akureyri, í boði Krabbameinsfélags Akureyrar og nágrennis. Gunnar Már Hauksson gjaldkeri og Arnar Hauksson voru fulltrúar Krabbameinsfélags Reykjavíkur.

Gjaldkeri okkar félags, Gunnar Már Hauksson, er fulltrúi í fjáröflunarráði Krabbameinsfélagsins. Pað hefur m.a. pað hlutverk að efla, samhæfa og hafa yfirumsjón með fjáröflun Krabbameinsfélags Íslands, svæðafélaga pess og stuðningshópa.

Varaformaður og fyrrum formaður eru í endurhæfingarteymi Landspítalans fyrir krabbameinsgreinda, teymið hefur staðið fyrir skipulagðri fræðslu með Ráðgjafarbjónustu Krabbameinsfélagsins fyrir krabbameinssjúklinga og aðstandendur.

Krabbameinsfélag Reykjavíkur hefur átt gott samstarf við Ráðgjafarbjónustu Krabbameinsfélagsins, hefur aðstoðað við útgáfumál, málping og ráðstefnur sem Ráðgjafarbjónustan stendur fyrir, og mun áfram styðja starfsemina eftir bestu getu.

Húsnefnd hefur verið starfandi mörg undanfarin ár og er framkvæmdastjóri Krabbameinsfélags Reykjavíkur í nefndinni.

Mörg verkefni félaganna eru unnin í samvinnu Jónasar Ragnarssonar og okkar. Gott samstarf er við starfsfólk Leitarstöðvarinnar og félagið aðstoðar við yfirlestur á ýmsum gögnum Leitarstöðvarinnar. Öðrum sviðum Krabbameinsfélags Íslands er líka veitt aðstoð við yfirlestur gagna og með pátttöku í skipulagningu ýmissa verkefna. „Heilsuhlaup Krabbameinsfélagsins“ var haldið í júní sl. og var Guðlaug í undirbúningshópi hlaupsins.

Félagið hefur átt gott samstarf við aðildarfélög og stuðningshópa Krabbameinsfélagsins, Morgunblaðið, Icepharma, Smáralind, starfsmenn Fræðslu og forvarna (FRÆ) og fleiri. Ásgeir Theódórs meltingarlæknir og Friðbjörn Sigurðsson krabbameinslæknir hafa ásamt stuðningsaðilum unnið mjög ötult starf í „ristilhópnum“. Einnig má minnast á afar gott samstarf við starfsfólk Arion banka og Advania varðandi happdrættið og fleira.

Guðlaug B. Guðjónsdóttir og Árni Einarsson. 


\section{Krabbameinsfélag Akraness og nágrennis}

Stofnað: 9. febrúar 1969. Félagsmenn: 300.

Póstfang: Pósthólf 107, 300 Akranesi.

Netfang akranes@krabb.is, vefsíða www.krabb.is/akranes

Skrifstofustjóri: Thelma Hrund Sigurbjörnsdóttir.

Stjórn kosin á aðalfundi 5. maí 2015:

Formaður: Ólöf Inga Birgisdóttir

8948835 olof.birgisdottir@hve.is

Gjaldkeri: $\quad$ Alma Auðunsdóttir

Meðstjórnandi: Helga Hallfríður Stefánsdóttir

Meðstjórnandi: Arndís Halla Jóhannesdóttir

Meðstjórnandi: Thelma Hrund Sigurbjörnsdóttir

\section{Starfsemi 2014-2015}

Starfsárið 2014-2015 hófst með söluhelgi í ágúst. Stjórnarmenn sáu um sölu á málböndum og spilastokkum merktum Krabbameinsfélaginu. Đar að auki útbjuggu stjórnarmenn til forláta handunnin skilti sem einnig voru seld til styrktar félaginu. Ágóðinn af pessari sölu rann til Krabbameinsfélags Akraness og nágrennis. Salan gekk ágætlega.

Í september fór aðalorkan í að undirbúa átakið, Bleika slaufan, sem er stærsti viðburður hvers árs hjá Krabbameinsfélaginu. Að pessu sinni var fyrsta slaufa ársins næld í unga konu að nafni Arndís Halla Jóhannesdóttir sem hefur vakið athygli á pjónustu við krabbameinsgreinda og aðbúnað heilbrigðisstarfsfólks. Arndís Halla hélt svo opinn fyrirlestur í febrúar sem bara heitið „Mikill hlátur og smá grátur“ og var hann vel sóttur.

Í október hefur verið venjan að lýsa eitt hús í bænum bleikt en að pessu sinni ákváðum við í samstarfi við Akraneskaupstað að lýsa Akratorgið bleikt. Verið var að taka í notkun nýjan ljósabúnað á Akratorgi í október og var pví tilvalið að slá tvær flugur í einu höggi og baða torgið bleikum ljósum. Stjórnarmenn seldu heitt kakó kvöldið sem ljósin voru kveikt og gekk sú sala vonum framar. Október endaði svo á bleikri rökkurgöngu í skógrækt okkar Akurnesinga og tókst sú ganga vel.

Veglegt fréttabréf var gefið út í nóvember par sem nýjar áherslur í starfi Krabbameinsfélagsins voru kynntar, skrifstofan á Kirkjubraut 40 var lögð niður og formleg samvinna hófst við Endurhæfingarhúsið Hver í byrjun desember 2014.

Félagið tók upp pá nýjung að bjóða upp á slökun og samtalsmeðferð fyrir nýgreinda einstaklinga og pá sem eru í meðferð. Rannveig Björk Gylfadóttir hjúkrunarfræðingur annast hana. Ágóðinn að ágústsölunni fór í kaup á hægindastól sem nýtist í slökuninni.

Jóga-námskeið voru haldin að hausti og vori og eru pau alltaf jafn vel sótt. Líkt og áður var pað Margrét Bára Jósefsdóttir sem sá um pau. Jógað er sívinsælt og er orðinn fastur liður í starfseminni. Jógað fór fram í húsnæði Hver á vorönninni og gekk pað vel.

Starfsárið hefur gengið vel, samvinnan við Hver hefur verið góð pótt færri einstaklingar hafi sótt pjónustuna en vonir stóðu til.

Félagið leggur áherslu á að nýta pá fjármuni sem safnast til góðra verka í págu krabbameinssjúklinga. Á yfirstandandi starfsári veitti félagið 250.000 kr. styrk til Hollvinasamtaka Heilbrigðisstofnunar Vesturlands sem standa að söfnun fyrir nýju sneiðmyndatæki. Auk pess var sama upphæð sett í vísindasjóð Krabbameinsfélags Íslands. 


\section{Krabbameinsfélag Borgarfjarðar}

Stofnað: 14. febrúar 1970.

Félagsmenn: Um 300.

Stjórn kosin á aðalfundi í nóvember 2014:

Formaður: $\quad$ Sigríður Helga Skúladóttir, bórólfsgötu 17a, 310 Borgarn. 8989246 sigga.sk@simnet.is

Varaformaður: Sæunn Elfa Sverrisdóttir, Hlöðutúni, 311 Borgarnesi

Ritari: $\quad$ Halla Magnúsdóttir, Kveldúlfsgötu 16, 310 Borgarnesi

Gjaldkeri: $\quad$ María Dórarinsdóttir, Mávakletti 6, 310 Borgarnesi

Meðstjórnandi: Líney Traustadóttir, Bjargarsteini, 311 Borgarnesi

\section{Starfsemi 2014}

Aðalfundur var haldinn síðla árs, var stjórnin endurkjörin og reikningar sampykktir. Formaður fór á aðalfund Krabbameinsfélags Î́slands í maí og á formannafund á Akureyri í október. Formaður tók pátt í nefndarstörfum á vegum Krabbameinsfélags Íslands.

Félagið tók pátt í fjáröflun á haustdögum. Í mars hélt félagið fjáröflunartónleika í Borgarneskirkju í samstarfi við karlakórinn Söngbræður. Minningarkort fást á Pósthúsinu, í Handavinnuhúsinu, Arionbanka og hjá formanni.

Eitt aðalmarkmið félagsins er að styðja við bakið á krabbameinssjúklingum á svæðinu og voru veittir styrkir og greitt fyrir húsaleigu til allmargra einstaklinga á árinu. Ræddar voru hugmyndir um samverustundir (stuðningshóp).

Sigríður Helga Skúladóttir.

\section{Krabbameinsfélag Snæfellsness}

Stofnað: 27. september 2005.

Félagsmenn: Um 85.

Stuðningshópur: Von. Upplýsingar gefur Margrét Hjálmarsdóttir, sími 8641767.

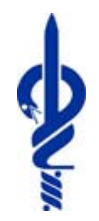

Stjórn kosin 28. apríl 2015:

Formaður: $\quad$ Sveinbjörg Eyvindsdóttir, Hellnum, 356 Snæfellsbæ $\quad 8665237$ bros88@simnet.is

Gjaldkeri: $\quad$ Magnea Sigurbj. Kristjánsdóttir, Fornu-Fróðá, 356 Snæf.

Ritari: $\quad$ Guðmunda H. Pórðardóttir, Bárðarási 1, 360 Snæfellsbæ

Meðstjórnandi: Svanborg Siggeirsdóttir, Sundabakka 16, 340 Stykkishólmi

Meðstjórnandi: Margrét Hjálmarsdóttir, Fagurhólstúni 14, 350 Grundarf.

\section{Starfsemi 2014-2015}

Áttundi aðalfundur félagsins var haldinn 26. apríl 2012. Starf hefur að mestu legið niðri fyrir utan árlega hefðbundna fjáröflun. Níundi aðalfundurinn var haldinn 28. apríl 2015. Ein breyting var á stjórn.

Í tilefni af pví að félagið fagnar 10 ára afmæli á pessu ári ákvað aðalfundur að gefa veglegar peningagjafir í nýjan vísindasjóð Krabbameinsfélags Íslands og til Ljóssins.

Stuðningshópurinn Von í Grundarfirði hefur eins og undanfarin ár haldið sína mánaðarlegu fundi fyrsta priðjudag hvers mánaðar. Að venju hefur félagið tekið pátt í dvalarkostnaði vegna lækninga fjarri heimabyggð. Nokkrar beiðnir um aðra fjárstyrki bárust sem hægt var að sinna.

Sveinbjörg Eyvindsdóttir. 


\section{Krabbameinsfélag Breiðfirðinga}

Stofnað: 19. október 2005.

Félagsmenn: 45.

Stjórn kosin á aðalfundi 12. maí 2014:

Formaður: $\quad$ Jóna Valgerður Kristjánsd., Mýrartungu 2, 380 Reykh.

8936396 j.valgerdur@gmail.com

Ritari: $\quad$ Guðrún Björnsdóttir, Sunnubraut, Búðardal

Gjaldkeri: $\quad$ Ingibjörg Kristjánsdóttir, Garpsdal, Reykhólahreppi

Meðstjórnandi: Indíana S. Ólafsdóttir, Hellisbraut 16, Reykhólum

Meðstjórnandi: prúður Kristjánsdóttir, Sunnubraut 19, Búðardal

\section{Starfsemi 2014}

Aðalfundurinn árið 2014 var haldinn 12. maí í Tjarnarlundi í Saurbæ. Við höldum aðalfundina til skiptis í byggðarlögunum premur. par dreifðum við ýmsum fræðslubæklingum Krabbameinsfélagsins og kynntum pá. Einn stjórnarfundur var haldinn á árinu og nokkrir símafundir, en stjórnin heldur aðallega símafundi vegna fjarlægðar á milli stjórnarmanna. Jóna Valgerður Kristjánsdóttir mætti á aðalfund Krabbameinsfélags Íslands sem haldinn var 10. maí 2014. Enginn mætti á formannafund Krabbameinsfélagsins haustið 2014. Enginn starfsmaður er launaður hjá félaginu og vinna stjórnarmenn pað sem gera parf í sjálfboðavinnu.

Við höfum árlega sent auglýsingu inn á hvert heimili á svæðinu par sem við kynnum íbúðir fyrir krabbameinssjúklinga og aðstandendur sem Krabbameinsfélagið á í Reykjavík og jafnframt að við greiðum dvalarkostnað peirra sem par dvelja af okkar félagssvæði pegar peir purfa á að halda vegna krabbameinsmeðferðar í Reykjavík. Einnig greiðum við fyrir fólk sem parf að vera á sjúkrahóteli Landsspítala. Við höfum lofað styrk til Heilsugæslunnar í Búðardal vegna kaupa á ýmsum tækjum til krabbameinsskoðunar sem keypt voru á árinu, en upphæð liggur ekki fyrir.

Á árinu seldum við jólakort félagsins, minningarkort, bleiku slaufuna og skeggnæluna við ýmis tækifæri. Bleika slaufan selst alltaf vel en pað sama er ekki hægt að segja um skeggnæluna. Minningarkortin eru jafnframt til sölu í Arion banka í Búðardal og einnig hjá stjórnarmeðlimum. Síðasta sumar voru spil, málbönd og varasalvi einnig selt í Handverkshúsinu Bolla í Búðardal og í Markaðnum í Króksfjarðarnesi sem Handverksfélagið Assa rekur á sumrin. Pá var einnig gengið í hús í Reykhólasveit og seld nokkur málbönd. Á jólamarkaðnum í Króksfjarðarnesi í nóvember voru jólakort frá okkur, vörur, og ýmsir jólamunir einnig til sölu, og stóð formaður vaktina við söluna í tvo daga.

Reykhólakirkja var lýst upp með bleiku ljósi í október og var pað í annað sinn sem pað er gert. Đá var einnig Mjólkurstöðin í Búðardal lýst upp með bleikum ljósum og er pað í fimmta skipti sem pað er gert. Starfsfólk Mjólkurstöðvarinnar tekur pað að sér.

Jóna Valgerður Kristjánsdóttir. 


\section{Krabbameinsfélag Tálknafjarðar og Vesturbyggðar}

Stofnað: 9. nóvember 2004 (áður Krabbameinsfélag Barðastrandarsýslu, stofnað 30. nóvember 1970).

Félagsmenn: Um 75.

Stjórn:

Formaður: ～Kolfinna Guðmundsdóttir, Urðargötu 22, 450 Patreksfirði 8615131 olist@visir.is

Gjaldkeri: Jóhanna Gísladóttir

Ritari: $\quad$ Duríður Ingimundardóttir

Meðstjórnandi: Birna Kristinsdóttir

Meðstjórnandi: Nína Jóhannesdóttir

\section{Starfsemi 2013-2014}

Félagið hefur selt minningarkort og styrkt fólk sem hefur farið í meðferð. Að öðru leyti hefur starfið ekki verið mikið.

Kolfinna Guðmundsdóttir.

\section{Krabbameinsfélagið Sigurvon}

Stofnað: 4. nóvember 2001. Kennitala: 470102-4540. Félagsmenn: Um 300.

Netfang sigurvon@snerpa.is, vefsíður http://svon.blogspot.com og

www.facebook.com/KrabbameinsfélagiðSigurvon

pjónustuskrifstofa: Pollgötu 4, Ísafirði, símar 4565650 og 8496560 ,

opin á priðjudögum og fimmtudögum kl. 11-13.

Starfsmaður: Thelma Hjaltadóttir.

Stuðningshópur: Vinir í von

Stjórn kosin á aðalfundi 27. mars 2015:

Formaður: $\quad$ Sigurður Ólafsson, Hlíðarvegi 45, 400 Ísafirði

Gjaldkeri: $\quad$ Guðfinna Sigurjónsdóttir, Ísafirði

Ritari: $\quad$ Oddný B. Birgisdóttir, Ísafirði

Meðstjórnandi: Svava B. Porsteinsdóttir, Ísafirði

Meðstjórnandi: Guðbjörg Ólafsdóttir, Ísafirði

\section{Starfsemi 2014}

Fjölbreytt starf var hjá Krabbameinsfélaginu Sigurvon árið 2014. Sem fyrr var stuðningshópurinn Vinir í von með öflugt starf. Hópurinn er með samverustundir annan hvern laugardag yfir vetrartímann par sem einstaklingar með krabbamein og aðstandendur peirra koma saman og eiga góða stund. Hópurinn hefur notið velvildar Vesturafls, geðræktarmiðstöðvar, sem lætur honum í té aðstöðu að Mánagötu 6.

Sigurvon lagði sitt af mörkum til að vekja athygli á Mottumars, árlegu árvekni- og fjáröflunarátaki Krabbameinsfélags Íslands. Veitinga- og skemmtistaðurinn Húsið á Îsafirði stóð fyrir svokallaðri mottukeppni par sem sex einstaklingar kepptu um pað hver skartaði flottustu mottunni. Auk pess að vekja athygli á átakinu var keppnin haldin til styrktar átakinu. Standa vonir til að um verði að ræða árvissan viðburð.

Félagið stóð einnig í marsmánuði fyrir svokölluðum blettadegi í samstarfi við heilsugæslu sjúkrahússins á Ísafirði og Porstein Guðmundsson lækni. Aðstandendur Sigurvonar eru afar pakklátir, bæði heilsugæslunni og framlagi porsteins. Alls nýttu 39 konur 28 karlar sér fría blettaskoðun og aldursbilið spannaði 
fæðingardaga frá 1930 til 2010. Var almenn ánægja með petta framtak. Af peim 67 sem nýttu sér skoðunina var rúmlega 20 einstaklingum vísað áfram í að láta fjarlægja bletti.

Víða var lýst upp með bleiku ljósi á Ísafirði í október og vakin athygli á að mánuðurinn er tileinkaður baráttunni gegn krabbameini hjá konum. Að vanda var Safnahúsið baðað bleikum ljóma sem og fleiri fyrirtæki og stofnanir hér í bæ sem eins flögguðu fána með bleiku slaufunni.

Aðalfundur félagsins var haldinn í mars og varð par engin breyting milli ára á stjórn félagsins.

Að vanda var haldin jólakortasala í fjáröflunarskyni en að pessu sinni var einnig efnt til útgáfu dagatals. Eins og undanfarin ár fékk félagið að gjöf myndir frá áhugaljósmyndaranum Ágústi G. Atlasyni til að skreyta kortin. Kann félagið honum bestu pakkir fyrir. Grunnskólabörn á norðanverðum Vestfjörðum gengu í hús og buðu hvort tveggja til sölu auk pess sem varningurinn var til sölu í ýmsum verslunum og í gegnum félagið.

Engin breyting var á peirri velvild sem Sigurvon var sýnd á árinu og styrktu pó nokkrir aðilar starfsemi félagsins. Er sá stuðningur ómetanlegur par sem hann gerir félaginu kleift að styðja við pá sem veikjast af krabbameini.

Thelma Hjaltadóttir.

\section{Krabbameinsfélag Hvammstangalæknishéraðs}

Stofnað: 13. október 1968.

Félagsmenn: Um 70.

Stjórn:

Formaður: Geir Karlsson, Spítalastíg 5, 530 Hvammstanga

4552100 geir.karlsson@hve.is

Ritari: Jóna G. Ármannsdóttir Laxárdal, 500 Stað

Gjaldkeri: $\quad$ Sigurbjörg Geirsdóttir, Búrfelli, 531 Hvammstanga

Meðstjórnandi: Malín Sigurbjörg Karlsdóttir, Melavegi 16, 530 Hvammst.

Meðstjórnandi: Elsche Apel, Neðri-Svertingsstöðum, 531 Hvammstanga

\section{Starfsemi 2014-2015}

Tekjur hafa verið af sölu innkaupapoka og minningarkorta ásamt beinum styrkjum frá félögum og einstaklingum. Annað hvert ár hefur verið haustmarkaður, svonefndur Sláturbasar, með landbúnaðarvörur og ýmislegt annað sem einstaklingar gefa, yfirleitt eitthvað sem peir eru að búa til eða rækta sjálfir.

Veittir voru styrkir til krabbameinssjúklinga, til að standa straum af læknis- og rannsóknakostnaði sem hið opinbera greiðir ekki. Félagið hefur í gengum árin styrkt forvarnarverkefni í skólum og Heilbrigðisstofnun Vesturlands á Hvammstanga með tækjakaupum.

Geir Karlsson. 


\section{Krabbameinsfélag Austur-Húnavatnssýslu}

Stofnað á Blönduósi: 2. nóvember 1968.

Félagsmenn: Um 200.

Stuðningshópur: Samhugur.

Stjórn kosin á aðalfundi 31. mars 2015:

Formaður: $\quad$ Sveinfríður Sigurpálsd., Brekkubyggð 11, 540 Blönduósi 4524528 sveinfridur@simnet.is

Ritari: $\quad$ Sigríður Stefánsdóttir, Hólabraut 23, 545 Skagaströnd

Gjaldkeri: $\quad$ Jökulrós Grímsdóttir, Bogabraut 3, 545 Skagaströnd

Meðstjórnandi: Katrín Líndal, Hlíðarbraut 17, 540 Blönduósi

Meðstjórnandi: Kristín Rós Sigurðardóttir, Tindum, 541 Blönduósi

\section{Starfsemi 2014-2015}

Stjórnin hélt hefðbundna fundi í árinu og hafði par fyrir utan mikil samskipti sín á milli gegnum tölvupóst og síma. Í lögum félagsins er hlutverk félagsins m.a. að fræða almenning um krabbamein og varnir gegn pví. Á aðalfundi 2014 flutti fyrirlesari okkur fræðslu um jóga-aðferðina og á aðalfundi 2015 fengum við fyrirlestur fluttan af Arndísi Höllu Jóhannesdóttur. Arndís er öflug ung kona, markpjálfi og proskabjálfi, og nefndi hún fyrirlesturinn „Mikill hlátur og smá grátur“ og velti hún pví upp hvernig við bregðumst við pví sem við purfum að takast á í vinnu eða einkalífi.

Fastir pættir svo sem fjáröflun til styrktar félaginu svo sem haustsalan á ýmsum hlutum haustið 2014 tókst vel. Sala á minningarkortum félagsins gekk einnig vel og fer aðallega fram í apóteki Lyfju á Blönduósi en einnig hjá félagsmönnum.

Félagið tók að venju pátt í árvekniátakinu í október sem fram fer til að minna á baráttu gegn brjóstakrabbameini sem og öđrum krabbameinum í konum. Í tilefni bess voru lýstar upp stofnun á Blönduósi og kirkjan á Skagaströnd. Stjórnarkonur tóku einnig pátt í sölu á ýmsum hlutum í átakinu Mottumars, karlar og krabbamein, sem fjáröflun fyrir okkar félag. Gekk sú söfnun býsna vel og pakka ber stjórnarkonum.

Félagið veitti nokkra styrki til peirra sem voru í meðferð við krabbameini, með pví að greiða leigu peirra fyrir íbúðir Krabbameinsfélagsins og annarra sem og í leiguíbúðar hjá Barnadeild Landspítalanum.

Einnig var söfnunarfé okkar notað til kaupa verkjalyfjadælu fyrir Heilbrigðisstofnunina Blönduósi og veittur var 200.000 kr. styrkur til söfnunarátaks sem Krabbameinsfélag Akureyrar og nágrennis stendur fyrir til kaupa á nýju ómskoðunartæki, staðsett á Sjúkrahúsinu á Akureyri.

Formaður sendi sem áður pistil um félagið í Húnavökutímaritið sem kemur út árlega og til upplýsinga um hvað er á döfinni hjá okkur og til að kynna starfsemina jafnframt.

Formaður sat formannafundinn sem haldinn var á Akureyri og í boði Krabbameinsfélags Akureyrar og nágrennis. Par voru m.a. fluttir áhugaverðir fyrirlestrar og kynnt handbók Gunnjónu Unu Guðmundsdóttur og eru upplýsingar handbókarinnar mjög parft verk og fræðandi.

Félaginu barst góður styrkur að upphæð 100.000 kr. frá Iðnsveinafélagi Húnvetninga sem sýnir velvilja í garð félagsins og fá Iðnsveinar bestu pakkir fyrir.

Félagsmönnum hefur pví miður farið fækkandi um árabil og ætlar stjórnin að bregðast ötullega við pví á næsta starfsári.

Sveinfríður Sigurpálsdóttir. 


\section{Krabbameinsfélag Skagafjarðar}

Stofnað: 12. júní 1966. Félagsmenn: Um 420.

pjónustuskrifstofa er á Heilbrigðisstofnuninni á Sauðárkróki.

Símar 4536030 og 863 6039. Starfsmaður: María Reykdal.

Netfang skagafjordur@krabb.is, vefsíða krabb.is/skagafjordur

Stuðningshópur: Dugur.

Stjórn kosin á aðalfundi í apríl 2015:

Formaður: Dalla Dórðardóttir, Miklabæ, 560 Varmahlíð

Ritari: $\quad$ Sara Valdimarsdóttir, Frostastöðum, 560 Varmahlíð

Gjaldkeri: $\quad$ Helga Gígja Sigurðardóttir

Meðstjórnandi: Ágústa Eiríksdóttir

Meðstjórnandi: Guðmundur Gunnarsson

Meðstjórnandi: Dorsteinn Dorsteinsson

\section{Starfsemi 2014-2015}

Starfsemi hefur verið talsverð. María Reykdal hefur verið með viðveru á skrifstofunni prjá daga í viku og er alltaf með auglýstan síma. Hún hefur verið með stuðningsviðtöl í síma og á stofu og einnig nokkur sálfræðiviðtöl.

Haldinn var einn stjórnarfundur. Félagið sendi tvo fulltrúa á aðalfund og starfsmaður fór á formannafund Krabbameinsfélagsins en formaður átti ekki heimangengt. Dugur hefur verið með samverustundir einu sinni í mánuði yfir vetrartímann. Fyrirhugaður er aðalfundur 29. apríl 2015.

Orlofsdvalir á Löngumýri voru studdar fjárhagslega. Félagið greiðir leigu fyrir fólk héðan sem dvelur í íbúðum Krabbameinsfélagsins eða á Sjúkrahótelinu í tengslum við krabbameinsmeðferð og hafa nokkrir nýtt sér pað og fengu aðstoð við pað af starfsmanni.

Heilbrigðisstofnunin og Sauðárkrókskirkja voru lýst bleik í október.

Krabbameinsfélagið greiðir niður fimm viðtöl sálfræðings fyrir sjúkling og/eða aðstandanda og hafa nokkrir aðilar nýtt sér pað. Félagið hefur veitt nokkra einstaklingsstyrki við sérstakar aðstæður.

Kiwanis setti í gang mikla fjársöfnun til pess að koma af stað kembileit vegna ristilkrabbameins, pannig að einum árgangi (55 ára) í senn yrði boðið í ristilspeglun. Fjársöfnunin yrði pannig að tryggt yrði að petta stæði til boða í 5 ár og yrði eins og verið hefur á Húsavík í bráðum 4 ár, en par með stuðningi Lions. Til pess að petta yrði mögulegt purfti einnig að safna fyrir nýju ristilspeglunartæki. Detta fór af stað í samráði við Krabbameinsfélag Skagafjarðar og hefur formaður setið nokkra fundi með Kiwanismönnum. betta fór einnig af stað í samráði við Heilbrigðisstofnunina á Sauðárkróki. Petta tókst með miklum glæsibrag og var Heilbrigðisstofnun Norðurlands Sauðárkróki afhent mjög fullkomið ristilspeglunartæki nú í mars og reyndar einnig magaspeglunartæki ásamt pvottavél fyrir tækin. Söfnuðust alls um 19 milljónir króna fyrir tækjunum fyrir utan söfnunina fyrir átakið sjálft. Afhendingin fór fram á mikilli samkomu í Miðgarði par sem sungu margir kórar og haldin fræðsluerindi og var í leiðinni fjáröflunarsamkoma. Skimunarátakið er nú pegar farið af stað. Söfnunin stendur undir kostnaðarhluta sjúklings en Heilbrigðisstofnunin gefur vinnuna við speglanirnar. betta átak og söfnun hefur vakið mikla athygli og verið gert skil á N4 og einnig í fréttum RUV. Formaður var boðinn á fund með Kiwanis og kynnti par speglunartækin og starfsemi Krabbameinsfélags Skagafjarðar. Viðruð hefur verið sú hugmynd við Kiwanis-félaga að liðsmaður peirra komi í stjórn Krabbameinsfélagsins og pví verið vel tekið en ekki enn frágengið.

Dorsteinn Dorsteinsson. 


\section{Krabbameinsfélag Akureyrar og nágrennis}

Stofnað: 21. nóvember 1952. Félagsmenn: 1.360.

pjónustuskrifstofa er á Glerárgötu 24, 600 Akureyri.

Opið er mánudaga og priðjudaga kl. 13-16.

Viðtalstímar við hjúkrunarfræðing eftir samkomulagi.

Sími 461 1470. Netfang kaon@simnet.is.

Framkvæmdastjóri: Dorbjörg Ingvadóttir.

Stuðningshópur: Norðankraftur.

Stjórn kosin á aðalfundi 2014:

$\begin{array}{ll}\text { Formaður: } & \text { Hlíf Guðmundsdóttir, Illugastöðum, 601 Akureyri } \\ \text { Varaformaður: } & \text { Friðrik Vagn Guðjónsson, Dalsgerði 4a, 600 Akureyri } \\ \text { Ritari: } & \text { Klara Arnbjörnsdóttir, Ólafsvegi 34, 625 Ólafsfirði } \\ \text { Gjaldkeri: } & \text { Jón D. Óskarsson, Illugastöðum, 601 Akureyri } \\ \text { Meðstjórnandi: } & \text { Anna Ólafsdóttir } \\ \text { Meðstjórnandi: } & \text { Guðbjörg Antonsdóttir, Skíðabraut 17, 620 Dalvík } \\ \text { Meðstjórnandi: } & \text { Hólmfríður Kristjánsdóttir, Eyrarlandsvegi 20, 600 Ak. } \\ \text { Meðstjórnandi: } & \text { Lilja Sverrisdóttir, Gullbrekku, 601 Akureyri } \\ \text { Meðstjórnandi: } & \text { Sigríður Jónsdóttir, Bergi, Svalbarðsströnd, 601 Akureyri }\end{array}$

\section{Starfsemi 2014}

Skrifstofan er í leiguhúsnæði að Glerárgötu 24 á Akureyri og er opin mánudaga og priðjudaga frá kl. 13 til 16, auk pess sem boðið er uppá viðtalstíma utan opnunartíma á skrifstofunni.Simatími er alla miðvikudaga frá kl. 10-12. Starfsmenn eru prír og skipta á milli sín 90\% stöðu. Dorbjörg Ingvadóttir framkvæmdastjóri, Jóhanna Júlíusdóttir hjúkrunarfræðingur og Halldóra Björg Sævarsdóttir textílkennari, auk pess sem Sigrún Jónsdóttir sjúkrapjálfari starfar í nánum tengslum við félagið.

Aðalfundur félagsins var haldinn á Akureyri 20. maí 2014. Stjórn lagði fram tillögu um að árgjald til félagsins yrði óbreytt frá síðasta ári, eða 3.000 kr. og var sú tillaga sampykkt. Engar breytingar urðu á stjórn félagsins að pessu sinni. Stjórnin hélt fimm bókaða stjórnarfundi á árinu 2014.

Samskipti við Krabbameinsfélag Íslands. Aðalfundur Krabbameinsfélags Íslands var haldinn 10. maí og fulltrúi Krabbameinsfélags Akureyrar og nágrennis á peim fundi var Friðrik Vagn Guðjónsson auk pess sem Jóhanna Júlíusdóttir og Halldóra Björg Sævarsdóttur sátu fundinn. Formannafundur Krabbameinsfélags Íslands var haldinn á Akureyri 4. október og sá Krabbameinsfélag Akureyrar og nágrennis um alla umgjörð er varðaði fundinn. Starfsmenn sóttu tvo samráðsfundi starfsmanna svæðaskrifstofa Krabbameinsfélagsins.

Starfsemin. Mjög öflug starfsemi er rekin á vegum og í tengslum við Krabbameinsfélag Akureyrar og nágrennis. Skráðar heimsóknir á skrifstofu félagsins á árinu 2014 eru 465. Detta eru að langmestu leyti einstaklingar sem sækja Opið handavinnuhús, slökun, jóga og liðkandi æfingar auk fræðslufunda sem haldnir eru á vegum félagsins. Má par t.d. nefna námskeiðið Gott útlit betri líðan, heilsuréttarnámskeiðið Sætt án samviskubits, námskeið í orkeringu o.fl. Í hverri viku sækja á u.p.b. 20 einstaklingar samveru á Keramikloftinu, og skráð viðtöl (bæði komur á skrifstofu og símaviðtöl) eru skráð 114 á árinu. Kostnaður félagsins vegna aukinnar starfsemi og stuðnings við krabbameinsgreinda og fjölskyldur peirra hefur aukist verulega á milli áranna 2013 og 2014 og munar par tæplega 1.000.000 kr. á milli ára. Greiðsla vegna dvalarkostnaðar sjúklinga í íbúðum Krabbameinsfélagsins hefur líka aukist verulega milli ára og er nú rétt tæplega ein milljón króna miðað við rúmlega 400.000 kr. árið 2013.

Fræðsla/fundir o.fl. Starfsmenn sinna ýmis konar fræðslu sem tengist forvörnum, stuðningi og kynningu á starfsemi félagsins, bæði til hópa og einstaklinga. 
Endurhæfing. Sigrún Jónsdóttir sjúkrapjálfari hefur boðið bæði krabbameinssjúkum og langveikum upp á ókeypis hugleiðslu og slökun alla priðjudaga í húsnæði félagsins, auk pess að vera með vatnsleikfimi í innilaug Sundlaugar Akureyrar, styrktarbjálfun fyrir hópa í Eflingu og einstaklingspjálfun, viðtöl og ráðleggingar.

Opið handavinnuhús er í boði alla fimmtudaga frá kl. 13-17 og hefur verið mjög vel sótt. Umsjón hefur Halldóra Björg Sævarsdóttur textílkennari og er boðið upp á samveru par sem fólk getur komið með handavinnu og spjallað saman yfir kaffibolla. Auk pess sem sérstök fræðsla um valin verkefni hefur verið nokkrum sinnum í vetur í tengslum við Opna húsið.

Keramikloftið og Punkturinn. Á hverjum miðvikudegi frá kl. 13-18 hittist fólk á Keramikloftinu. Par er hægt аð vinna með gler, mosaik, keramik o.fl. Dessi samvera hefur gefist vel og hefur verið mjög vel sótt. Krabbameinsfélag Akureyrar og nágrennis hefur stutt við pessa starfsemi með ýmsu móti frá byrjun. Á Punktinum getur fólk komið alla fimmtudagsmorgna og nýtt pá aðstöðu sem par er í boði og fengið aðstoð og leiðbeiningar t.d. við saumaskap, útskurð, bókband o.m.fl.

Viðtöl og stuðningur við skjólstæðinga. Skráð viðtöl og símtöl eru 114. Starfsmenn hafa frá árinu 1998 haldið utan um fjölda viðtala á skrifstofunni.

Stómasamtökin hafa haldið fundi sína í húsnæði félagsins eins og undanfarin ár.

Líf og loft eru samtök lungnasjúklinga. Dau hafa fundað í húsnæði okkar.

Íbúðir Krabbameinsfélagsins í Reykjavík. Um áramótin 2014/15 höfðu félaginu borist reikningar vegna dvalar í íbúðum Krabbameinsfélagsin vegna 533 gistinátta. Hver sólarhringur kostar 1.850 kr. og greiddi félagið fyrri hluta ársins 75\% af hverjum reikningi, en á haustdögum ákvað stjórn Krabbameinsfélag Akureyrar og nágrennis að greiða pessa reikninga að fullu.

Tekjur og fjáraflanir. Helstu tekjur félagsins fyrir utan rekstarstyrk frá Krabbameinsfélagi Íslands sem greiðir helming af launum starfsmanna og verkefnisstyrk sem gerir okkur kleift m.a. að halda námskeið fyrir krabbameinssjúklinga og aðstandendur, eru félagsgjöldin og styrkir sem félaginu bárust frá félagasamtökum og einstaklingum á árinu. Sem dæmi má nefna að Félag matreiðslumeistara á Norðurlandi var með hátíðarkvöldverð á Hótel KEA í október, par sem fyrirtæki á svæðinu keyptu miða og buðu síðan útvöldum. Annað dæmi er fjáröflunarsamkoma sem tengdist Dömulegum dekurdögum á Icelandair hóteli í lok október. Sú velvild og sá stuðningur sem allir pessir fjölmörgu aðilar sýna okkur er ómetanlegur og gerir okkur kleift að styðja á margvíslegan hátt við bakið á peim íbúum á okkar félagssvæði sem greinast með krabbamein. Öllum pessum aðilum færum við innilega pakkir. Án pessa stuðnings væri petta ekki mögulegt.

Húsnæði. Krabbameinsfélag Akureyrar og nágrennis hefur í mörg ár leigt 110 fermetra húsnæði að Glerárgötu 24. Miklar endurbætur voru gerðar á húsnæðinu og salurinn okkar rúmar nú um 25-30 manns í sæti, auk pess sem rýminu er skipt pannig að auðvelt er að eiga notarlegt spjall við einstaklinga á fleiri en einum stað og segja má að vel hafi tekist til með endurbætur.

Samskipti við fjölmiðla. Starfsmenn hafa átt mjög góð samskipti við fjölmiðla á félagssvæðinu og hafa bæði birst viðtöl í Dagblöðum og tímaritum, auk pess sem allir starfsmenn hafa komið oftar en einu sinni í sjónvarpsviðtöl vegna ýmissa viðburða sem tengjast t.d. starfsemi félagins auk pess að vekja athygli á ýmsu sem hefur verið ofarlega á baugi í almennri umræðu í bjóðfélaginu. N4 sjónvarp hefur verið okkur sérlega vinsamlegt með аð kynna starfsemi okkar og koma til móts við kostnað vegna auglýsinga t.d. í Sjónvarpsdagskránni. Færum við peim bestu pakkir fyrir.

Dorbjörg Ingvadóttir. 


\section{Krabbameinsfélag Suður-Dingeyinga}

Stofnað: 22. ágúst 1968.

Félagsmenn: Um 400.

Stuðningshópur: Birta

Stjórn 2013:

Formaður: $\quad$ Jóhanna Björnsdóttir, Sólbrekku 7, 640 Húsavík

8628792 j.bjornsd@gmail.com

Ritari: $\quad$ Halla Lovísa Loftsdóttir, Álftanesi, 641 Húsavík

Gjaldkeri: $\quad$ Edda Björg Sverrisdóttir, Laugarholti 7, 640 Húsavík

Meðstjórnandi: Erla Sigurðardóttir, Höfðavegi 22, 640 Húsavík

Meðstjórnandi: Gunnlaug María Eiðsdóttir, Heiðargerði 4, 640 Húsavík

Meðstjórnandi: Ingigerður Arnljótsdóttir, Gautlöndum, 660 Mývatni

\section{Starfsemi 2014-2015}

Segja má að starfsemi Krabbameinsfélags Suður-Dingeyinga hafi verið með hefðbundnum hætti síðastliðið starfsár. Haustið hófst með sölu á ýmsum varningi merkt Krabbameinsfélaginu til ágóða fyrir félagið. Einnig stendur félagið fyrir sölu á minningarkortum par sem ágóðinn rennur óskiptur til Krabbameinsfélags Suðurpingeyinga. Í október stóð félagið fyrir pví að hvetja fyrirtæki og stofnanir að lýsa byggingar sínar bleikar, og í framhaldi af pví buðum við pingeyskum konum í „Bleikt boð“ á Húsavík. Í pessum boðum okkar fáum við góða fyrirlesara, fyrirtæki á svæðinu er með kynningu á sínum varningi eða starfsemi og síðast en ekki síst er gott skemmtiatriði með í farteskinu. Að pessu sinni var Friðbjörn Sigurðsson krabbameinslæknir með fyrirlestur um konur og krabbamein með áherslu á leghálskrabbamein. Friðbjörn hefur áður verið með fyrirlestur hjá félaginu og fær mikið lof fyrir og viljum við pakka honum fyrir gott og óeigingjarnt starf. pannig hefur hist á að pað hefur skollið á óveður pegar við höfum haldið pessi boð okkar og hefur Friðbjörn lagt mikið á sig að keyra yfir Víkurskarðið i óveðri og leiðindafærð.

Snyrtistofan á staðnum var með kynningu á vörum sem hjálpa til við að ná heilbrigðari og péttari augnhárum og augnbrúnum sem skiptir konur máli í krabbameinsmeðferð. Í lokin var boðið upp á veitingar og ljúfa tóna.

Eftir áramótin hefur starfsemin verið í lágmarki og stjórnast pað meðal annars af pví að við erum með pessi „boð“ (bleikt boð fyrir konur og blátt boð fyrir karla) annað hvert ár og pá er starfsemin mjög virk.

Stjórn félagsins er óbreytt frá síðasta starfsári.

Jóhanna Björnsdóttir.

\section{Krabbameinsfélag Norðausturlands}

Stofnað: 18. ágúst 1970, endurvakið 2. maí 2006.

Félagsmenn: Um 85.

Stjórn kosin á aðalfundi 16. mars 2014:

Formaður: $\quad$ Stefanía V. Gísladóttir, Boðagerði 9, 670 Kópaskeri

8662977 disagisla@islandia.is

Ritari: $\quad$ Gréta Bergrún Jóhannesd., Fjarðarvegi 43, 680 Dórshöfn

Gjaldkeri: $\quad$ María Hermundardóttir, Ekrugötu 4, 670 Kópaskeri

Meðstjórnandi: Bjarney Hermundardóttir, Tunguseli, 681 Dórshöfn

Meðstjórnandi: Guðrún M. Sigurjónsdóttir, Höfða, 675 Raufarhöfn 


\section{Starfsemi 2014}

Starfsemi félagsins hefur að mestu leyti verið bundin við sölu minningarkorta og merkjasölu á starfssvæði félagsins. Minningarkort Krabbameinsfélagsins eru auglýst í auglýsingablaðinu Skeglunni, sem dreift er á starfssvæði okkar, par er vakin athygli á félaginu og bent á Ráðgjafarpjónustu Krabbameinsfélags Íslands.

Haldnir voru kynningarfundir á Pórshöfn og á Kópaskeri. Formaður og gjaldkeri sóttu aðalfund og formannafund Krabbameinsfélags Íslands.

Stefanía V. Gísladóttir.

\section{Krabbameinsfélag Austurlands}

Stofnað: 20. apríl 1970. Félagsmenn: 154.

pjónustuskrifstofa að Búðareyri 15 á Reyðarfirði, rekin í samvinnu við

Krabbameinsfélag Austfjarða, er opin á priðjudögum og fimmtudögum kl. 11-13.

Sími 474 1530, netfang kraus@simnet.is, vefsíða krabb.is/austur

Starfsmaður: Tinna Hrönn Smáradóttir.

Stjórn kosin á aðalfundi 30. apríl 2015:

Formaður: $\quad$ Alfreð Steinar Rafnsson, Dalseli 8, 700 Egilsstöðum

Gjaldkeri: $\quad$ Kristjana Björnsd., Bakkavegi 1, 720 Borgarfirði eystra

Ritari: Jóna Björg Sveinsdóttir, Geitlandi, 720 Borgarfirði eystra

Meðstjórnandi: Ásdís Sigurjónsdóttir, Stekkjartröð 10, 700 Egilsstöðum

Meðstjórnandi: Karólína S. Ingvarsdóttir, Dalseli 8, 700 Egilsstöðum

8472524 alfred.steinar@gmail.com

8935211 kristbj.skima@simnet.is

8627865 jonasb@ismennt.is

8243920 asdiss@simnet.is

8243920 kain@mi.is

\section{Starfsemi 2014-2015}

Á aðalfundi Krabbameinsfélags Austurlands 2014 var stjórn félagsins falið að hefja viðræður við Starfsendurhæfingu Austurlands (StarfA) um samstarf og námskeiðahald fyrir skjólstæðinga félagsins.

Mikil pörf er á aðstoð við krabbameinsgreinda einstaklinga og fjölskyldur peirra á svæði félagsins, en ýmis vandamál hafa orðið pess valdandi að ekki hefur tekist að pjóna pessu fólki sem skyldi og má til dæmis nefna eftirfarandi: 1. Mikill kostnaður er í pví fólginn að fá aðkeypta bjónustu af höfuðborgarsvæðinu og ekki alltaf til reiðu pegar leitast hefur verið eftir pví. 2. Svæði félagsins tekur yfir stórt svæði og pví getur komið upp sú staða að auglýst námskeið nái ekki nægjanlegum fjölda vegna samgönguerfiðleika á svæðinu. 3. Mikil pörf er á pví að komið sé upp aðstöðu fyrir skjólstæðinga félagsins, óháð pví hvort námskeið eða endurhæfing standi yfir. Рað var álit stjórnar að útvega pyrfti húsnæði par sem skjólstæðingar félagsins geti komið saman og rætt sín mál í huggulegu og pægilegu umhverfi. Með hliðsjón af pví sem sett var fram hér аð framan hefur stjórn Krabbameinsfélags Austurlands gert samstarfsamning við StarfA sem felur í sér að skjólstæðingar félagsins hafa aðgang af öllum peim námskeiðum sem Starfsendurhæfingin rekur og skjólstæðingar félagsins kjósa sér. Undirbúningur að starfseminni er pegar hafinn og búið að festa húsnæði fyrir starfsemina og stefnt er af pví að formleg opnun verði 1. ágúst næstkomandi. pað er skoðun félagsins og StarfA að pörf sé á samstarfi við önnur félög sem eru á félagsvæðinu og hafa einnig á stefnuskrá sinni að aðstoða sína félagsmenn hver svo sem sjúkdómurinn er. Öll eiga pessi félög sameiginlegt að fjárskortur hamlar pví að geta pjónað sínum félagsmönnum eins og pau vildu gera, en með samstarfi pessara félaga má ná saman sterkri heild sem kemur öllum til góða. Nú pegar hafa farið fram óformlegar viðræður við önnur félög varðandi pessi mál sem kynnt verða. Allir peir sem rætt hefur verið við eru sammála um að sameinaðir stöndum við, en sundraðir föllum við. Rétt er að geta pess að pegar Oddfellow-reglan frétti af fyrirhuguðu verkefni ákvað kvennadeild reglunnar að færa félaginu að gjöf fartölvu til notkunar í væntanlegri aðstöðu félagsins.

Á formannafundi krabbameinsfélaganna á Akureyri í fyrrahaust kom pað skýrt fram hjá gjaldkera Krabbameinsfélags Íslands og formanni úthlutunarnefndar velunnarasjóðsins, Sigurði P. Sigmundssyni, að hann 
vildi gjarnan sjá nýjungar í umsóknum í velunnarsjóðinn. Í trausti pess að pessi skoðun sé enn í fullu gildi hefur verið sótt um styrk fyrir petta tilraunaverkefni til sjóðsins.

Krabbameinsfélag Austurlands er í samstarfi við Krabbameinsfélag Austfjarða um rekstur pjónustuskrifstofu á Reyðarfirði. Helstu útgjaldaliðir félagsins til pessa hefur verið hlutdeild í kostnaði við skrifstofuna á Reyðarfirði og fjárhagsaðstoð við sjúklinga vegna dvalar í Reykjavík meðan á meðferð stendur.

Skráðir félagar í Krabbameinsfélagi Austurlands voru um síðustu áramót 154. Gera parf gangskör að pví að fjölga félögum.

\section{Alfreð Steinar Rafnsson.}

\section{Krabbameinsfélag Austfjarða}

Stofnað: 21. apríl 1970. Félagsmenn: Um 480.

pjónustuskrifstofan að Búðareyri 15 á Reyðarfirði er rekin í samvinnu við Krabbameinsfélag Austurlands og er opin á priðjudögum og fimmtudögum kl. 11-13. Sími 474 1530. Vetrarstarf fer fram í Virknimiðstöðinni að Austurvegi 29 á Reyðarfirði. Netfang kraus@simnet.is

Starfsmaður: Tinna Hrönn Smáradóttir.

Stjórn kosin á aðalfundi 28. apríl 2015:

Formaður: Jóhann Sæberg Helgason, Heiðarvegi 20, 730 Reyðarfirði 8407212 johann@launafl.is

Ritari: $\quad$ Solveig Friðriksdóttir, Hólalandi 18, 755 Stöðvarfirði

Gjaldkeri: $\quad$ Jórunn Valdimarsdóttir, Sunnugerði 18, 730 Reyðarfirði

Meðstjórnandi: Anna Póra Árnadóttir, Blómsturvöllum 1a, 740 Neskaupstað

Meðstjórnandi: Anna R. Gunnarsdóttir, Stekkjargrund 6, 730 Reyðarfirði

Meðstjórnandi: Iðunn Geirsdóttir, Hjallavegi 4, 730 Reyðarfirði

Meðstjórnandi: Rafnkell Gíslason, Valsmýri 6, 740 Neskaupstað

\section{Starfsemi 2014}

Aðalfundur var haldinn í Safnaðarheimili Reyðarfjarðarkirkju 29. apríl 2014. Stjórn félagsins hélst óbreytt nema að pví leyti að Anna Ragnheiður Gunnarsdóttir tók við stöðu gjaldkera og Iðunn Geirsdóttir sem hafði verið gjaldkeri tók við af Önnu sem meðstjórnandi.

pjónustuskrifstofa: Í janúar hóf Tinna Hrönn Smáradóttir störf hjá félaginu í 50\% stöðu sem felur í sér pjónustu við félagsmenn eins og verið hefur en aukin prósenta felur í sér að koma á fót og sinna virknimiðstöð sem markmiðið var að koma á koppinn. Talsvert var fundað með fleiri aðilum um samstarf á pessum velli en pær viðræður fjöruðu út og pegar líða tók að hausti tók félagið af skarið og hóf leit að húsnæði. Í haust kom svo upp óvænt tækifæri pegar félaginu bauðst að fá afnot af húsnæði farfuglaheimilisins Hjá Marlín sem er staðsett í fyrrverandi Húsgagnaversluninni Hólmum við Austurveg á Reyðarfirði. Afnot af húsnæðinu eru félaginu að kostnaðarlausu og vill Marlín pannig styrkja félagið og má segja að pessi styrkur sé ómetanlegur og kunnum við Marlín bestu pakkir fyrir hennar framlag. Miðstöðin var opnuð formlega pann 30. nóvember 2014 par sem um 30 manns mættu.

Opið hús er haldið annan priðjudag í mánuði og hefur verið reynt að brydda uppá mismunandi umræðum og viðburðum. Einnig hefur virknimiðstöðin verið opin alla fimmtudaga kl.14-17.

Söfnunarátök: Mottumars gekk í garð með samkomu Hárstofu Sigríðar og Staupasteins á Reyðarfirði par sem m.a. var haldið uppboð par sem ágóðinn rann til félagsins, við vorum með sölubás par sem voru til sölu t.d. mottuherðatré, mottuhálsslaufur, skeggpinnar og fleira. Sömu aðilar héldu aftur konukvöld í október til styrktar félaginu par sem var haldið uppboð á munum sem listamenn höfðu gefið til styrktar málefninu og 
runnu upphæðirnar óskiptar til félagsins. Einnig voru farnar hefðbundnar leiðir í sölu á skeggpinnum í mars og haustsölunni.

Vinir Jóa: Í febrúar í fyrra tók félagið pátt í söfnun par sem nokkrir einstaklingar sem kölluðu sig „Vinir Jóa“ tóku sig saman og söfnuðu styrkjum til pess að kaupa rafskutlu fyrir góðan félaga sem vegna alvarlegra veikinda sinna hafði einangrast og komst ekki ferða sinna. Рað tókst á ótrúlega stuttum tíma og innan við mánuð frá pví að hugmyndin kviknaði var búið að safna fyrir og afhenda skutluna við mikla gleði Jóhannesar félaga okkar sem féll frá í haust. Petta dæmi sýnir grannt velviljann í samfélaginu okkar og er virkilega gaman að geta tekið pátt í svona verkefnum.

Hvíldarhelgin á Eiðum var skipulögð í paula með glæsilegri dagskrá, en vegna lélegrar pátttöku var sú ákvörðun tekin að blása hvíldarhelgina af og reyna aftur að ári.

Styrkir til einstaklinga: Sem fyrr hefur félagið styrkt einstaklinga sem hafa fengið afnot af íbúðunum á Rauðarárstíg og gist á Sjúkrahótelinu. ๖að er dýrt að verða veikur á Íslandi og pað sjáum við vel, pess vegna er starf félagsins okkar gríðarlega mikilvægt til að geta létt undir með fólki fjárhagslega og hefur pað aukist.

Styrkir frá fyrirtcekjum og einstaklingum: Við finnum fyrir mikilli velvild í garð félagsins og erum við afar pakklát fyrir pað. Margir einstaklingar, félög og fyrirtæki hafa lagt okkur lið og má par helst nefna Hárstofu Sigríðar og Staupastein varðandi konukvöldin, Tónleikafélag Reyðarfjarðar sem hélt flotta söngvarakeppni sem styrkt var af ýmsum fyrirtækjum og fékk félagið ágóðann sem var 400 púsund krónur, Sesam brauðhús seldi bleikar bollakökur í október og runnu 100 krónur af hverri bollaköku til félagsins, upphæðin varð 125.200 krónur sem pýðir að 1.252 bleikar bollakökur seldust, Kvenfélag Reyðarfjarðar afhenti 150 púsund krónur sem notaðar voru til að kaupa skjávarpa sem mun nýtast vel. Fjöldi annarra einstaklinga og fyrirtækja styrktu félagið með peningagjöfum, sem seint verður pakkað til fullnustu og virkar sem hvatning fyrir okkur að halda áfram okkar góða starfi og gera enn betur!

Tinna Hrönn Smáradóttir.

\section{Krabbameinsfélag Suðausturlands}

Stofnað: 21. apríl 1970 (endurvakið 1. október 2002).

Félagsmenn: 150.

Stjórn:

Formaður: $\quad$ Ester Porvaldsdóttir, Hólabraut 2, 780 Höfn

4782040 ester@hssa.is

Gjaldkeri: $\quad$ Ólöf Óladóttir, Austurbraut 19, 780 Höfn

Ritari: $\quad$ Eyrún Axelsdóttir, Silfurbraut 35, 780 Höfn

Meðstjórnandi: Hjálmar Jens Sigurðsson, Hrísbraut 12, 780 Höfn

Meðstjórnandi: Dórhildur G. Kristjánsdóttir, Svalbaði 5, 780 Höfn

\section{Starfsemi 2014-2015}

Félagið er með eigin minningarkort og tekur pátt í almennri vor- og haustfjáröflun á vegum Krabbameinsfélags Íslands og aðildarfélaga. Ávallt vel tekið á móti fólki pegar fjáraflanir eru í gangi. Veittir hafa verið styrkir til einstaklinga. Greiðir félagið jafnframt leiguhluta einstaklinga í krabbameinsmeðferð, hvort sem dvalið er í íbúðum Krabbameinsfélagsins eða gist á Sjúkrahótelinu meðferðardagana.

Góð mæting er á fræðslufundi sem félagið stendur fyrir. Í tilefni af mottumars 2014 var haldið fræðslu og karlakvöld í Pakkhúsinu við mjög góðar undirtektir par sem Teitur Guðmundsson læknir hélt fyrirlestur um karlmenn og karlaheilsu, „Stakir jakar“ fluttu nokkur hressileg lög og Hjálmar Jens Sigurðsson sjúkrabjálfari kynnti teygjuæfingar. Í október 2014, bleika mánuðinum, var haldið fræðslu- og kvennakvöld í Pakkhúsinu á vegum félagsins par sem Teitur Guðmundsson læknir hélt fyrirlestur um kvennaheilsu, Margrét Gauja Magnúsdóttir fór með örræðu og Matthildur Ásmundardóttir sjúkrabjálfari fór yfir réttar líkamsstellingar og 
slökunaræfingar. Í tilefni af Mottumars 2015 var haldið fræðslu- og karlakvöld á Hótel Höfn par sem Ágst Óskar Gústafsson heimilislæknir flutti fræðsluerindi um karla og krabbamein með áherslu á ristilkrabbamein. Tónlistaratriði voru flutt, Auðunn Helgason fótboltabjálfari flutti erindi. Mæting var mjög góð.

Í samvinnu við Krabbameinsfélag Reykjavíkur, par sem Ingibjörg K Stefánsdóttir hjúkrunarfræðingur handleiddi með námsefni, var haldið hér í febrúar og mars 2015 reykleysisnámskeið fyrir fyrirtæki á staðnum. Gafst petta fyrirkomulag mjög vel og er vonandi komið til með að vera.

Gott samstarf er á milli Heilbrigðisstofnunar Suðausturlands og félagsins, með áherslu á forvarnir og fræðslu.

Ester Porvaldsdóttir.

\section{Krabbameinsfélag Vestur-Skaftafellssýslu}

Stofnað: 6. maí 1971

(endurvakið 22. nóvember 2004 og aftur 5. maí 2009).

Stjórn kosin á aðalfundi 2. apríl 2013:

Formaður: $\quad$ Rannveig Bjarnadóttir, Skaftárvöllum 8, 880 Kirkjub.kl. 8657387 reb@simnet.is

Meðstjórnandi: Sigurður Elías Guðmundsson, Sunnubraut 8, 870 Vík

Gjaldkeri: $\quad$ Sigríður Dórothea Árnadóttir, Sigtúni 4, 870 Vík

Ritari: $\quad$ Margrét Einarsdóttir, Mörk, 880 Kirkjubæjarklaustri

Meðstjórnandi: Ingvar Jóhannesson, Höfðabrekku, 871 Vík

\section{Starfsemi 2014-2015}

Félagasamtök svo og einstaklingar hafa verið einstaklega velviljaðir félaginu. Hafa pví borist höfðinglegar peningaupphæðir og minningagjafir. Hver sá sem parf á krabbameinsmeðferð að halda og sækir um til félagsins fær styrk til endurgreiðslu á húsnæði á meðan á dvöl sjúklinga og aðstandenda stendur.

Lítið hefur verið um formlega fundi en við sjáum ekki annað en pað sé pörf fyrir slíkan félagsskap sem pennan og munum halda áfram að byggja upp félagið.

Rannveig Bjarnadóttir.

\section{Krabbameinsfélag Rangárvallasýslu}

Stofnað: 7. maí 1971 (endurvakið 15. apríl 1993).

Félagsmenn: Um 105.

Stjórn kosin 2012:

Formaður: $\quad$ Ólöf Árnadóttir, Bolöldu 2, 850 Hellu

Gjaldkeri: $\quad$ Dórdís Ingólfsdóttir, Kambi, 851 Hellu

6154606 olof@hsu.is

Meðstjórnandi: Guðríður Bjarnadóttir, prúðvangi 27, 850 Hellu

Meðstjórnandi: Lilja Einarsdóttir, Krókatúni 5, 860 Hvolsvelli

Meðstjórnandi: Sóley Ástvaldsdóttir, Stóragerði 9, 860 Hvolsvelli

\section{Starfsemi 2014-2015}

Starfsemin var að mestu leyti hefðbundin. Sala minningarkorta og önnur sala gekk vel. Formaður hefur heimsótt fólk sem greinst hefur með krabbamein og félagið hefur greitt fyrir dvöl í íbúðunum í Reykjavík.

Ólöf Árnadóttir. 


\section{Krabbameinsfélag Árnessýslu}

Stofnað: 29. maí 1971. Félagsmenn: Um 300.

pjónustuskrifstofa: Eyrarvegi 23 á Selfossi, opin á fimmtudögum kl. 13-16.

Starfsmaður: Erla Guðlaug Sigurjónsdóttir.

Sími: 788 0300. Netfang: arnessysla@krabb.is

Stuðningshópur: Bandið.

Stjórn kosin á aðalfundi 7. apríl 2014:

Formaður: $\quad$ Ingunn Stefánsdóttir, Fossi IV, 800 Selfossi

8623411 ingunn@heilsustofnun.is

Varaformaður: Eygló Aðalsteinsdóttir

Ritari: $\quad$ Rannveig Ingvadóttir, Hveraferði

Gjaldkeri: $\quad$ Ingibjörg Jóhannesdóttir

Meðstjórnandi: Sigríður Guðnadóttir

Meðstjórnandi: Sigrún Ásgeirsdóttir

Meðstjórnandi: Sigurbjörg Jónsdóttir

\section{Starfsemi 2014-2015}

pjónustuskrifstofan hefur verið opin í prjár klukkustundir á viku, á fimmtudögum kl. 13-16. Meira er haft samband í gegnum síma, tölvupóst eða á förnum vegi. Samtals voru skráð 217 samtöl.

Félagið tók pátt bæði í haustsölunni, par sem seldir voru pennar og spil, og í marssölunni par sem seldur var gamall varningur og bílaseglar. Tókst haustsalan mjög vel.

Selfosskirkja, Landsbankinn á Selfossi og Hraungerðiskirkja í Flóahrepp voru lýst upp bleik í október.

Sjálfhjálparhópurinn Bandið hittist fyrsta priðjudagskvöld í mánuði. Sálfræðingur leiddi fund í september og mataræði var tekið fyrir í október. Í nóvember ræddi hjúkrunarfræðingur um svefnvenjur og hvað er til ráða til að bæta svefninn. Jólasaga var lesin í desember.

Eftir áramótin var farið í samstarf við Árnesingadeild Rauða krossins og stofnaður hópur sem nefnist Brosið sem er með opið hús á fimmtudögum milli kl. 13-16. Ýmislegt verður í boði par svo sem fyrirlestrar, handverk og sýnikennsla, Ham-námskeið og fl.

Í marsmánuði urðu starfmannabreytingar og lét Rannveig Árnadóttir af störfum en Erla Guðlaug Sigurjónsdóttir hóf störf.

Rannveig Árnadóttir.

\section{Krabbavörn Vestmannaeyjum}

Stofnað: 25. apríl 1949 (endurvakið 3. maí 1990). Félagsmenn: 250.

Stuðningshópur: Eyjarós. Skrifstofa félagsins er opin á priðjudögum kl. 13-15.

Starfsmaður er Guðbjörg Erla Ragnarsdóttir.

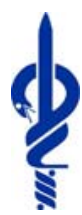

Stjórn kosin á aðalfundi 22. febrúar 2015:

Formaður: $\quad$ Ester Ólafsdóttir, Áshamri 12, 900 Vestmannaeyjum 8672218 baddie@simnet.is

Varaformaður: Margrét Grímlaug Kristjánsdóttir

Ritari: Dóra Björk Gústafsdóttir

Gjaldkeri: $\quad$ Sigríður Garðarsdóttir

Meðstjórnandi: Karólína Jósefsdóttir

Meðstjórnandi: Sigríður Ágústa Pórarinsdóttir 


\section{Starfsemi 2014-2015}

Skrifstofan er opin alla priðjudaga kl.13:00-15.00 og er hún að festa sig í sessi, alltaf kíkja einhverjir við. Magga og Ester eru par í sjálfboðavinnu, en Guðbjörg Erla sem var par starfsmaður dró sig í hlé í bili vegna veikinda.

Fyrsta fimmtudag í mánuði höfum við opinn fund par sem gott meðlæti er í boði sem við gerum sjálfar. Hafdís Kristjánsdóttir jógakennari var með fyrirlestur um meðvirkni og jákvæðni. Fórum á karlakvöld hjá Hjólbarðastofu Vestmannaeyja par sem okkur var afhent peningagjöf. Par hér í Eyjum sem gifti sig eftir áralanga sambúð bað gesti í brúðkaupsveislunni að í stað gjafa léti fólk af hendi rakna peningagjöf til Krabbavarnar. Eldri maður gaf stórgjöf til minningar um látna eignkonu sína. Handboltalið kvenna og karla gáfu ágóða af innkomu á handboltaleik. Ung stúlka tók pátt í Reykjavíkurmaraponi með áheitum á Krabbavörn. Tvær ungar stúlkur gáfu ágóða af blaðaútgáfu. Sjötindaganga og áramótaganga safnaði fjármunum. Tvær konur gáfu út dagatal og seldu. Vinur okkar er að ganga Jakops-veginn og safnar áheitum á Krabbavörn. BK-gler selur boli, svuntur og könnur fyrir okkur. Septembersalan gekk mjög vel, pað var bleikur bær í október og Mottumars flottur, flaggað fánum víða í bænum.

Gáfum eina milljón króna til Kvenfélagsins Líknar til kaupa á röntgentæki fyrir Heilbrigðisstofnunina. Einnig 500 púsund krónur í íbúðirnar sem fólkið okkar notar mjög mikið.

Ester Ólafsdóttir.

\section{Krabbameinsfélag Suðurnesja}

Stofnað: 15. nóvember 1953. Félagsmenn: Um 915.

Starfsmaður: Sigrún Ólafsdóttir. Stuðningshópur: Sunnan 5.

Skrifstofan að Smiðjuvöllum 8 er opin á priðjudögum og fimmtudögum kl. 12-16.

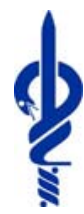

Stjórn kosin á aðalfundi 16. apríl 2015:

Formaður: Guðmundur Björnsson, Óðinsvöllum 14, 230 Reykjanesbæ662 6989 gudmbj@internet.is

Ritari: $\quad$ Friðfinnur Skaftason, Suðurvöllum 8, 230 Reykjanesbæ

Gjaldkeri: $\quad$ Grétar Grétarsson, Heiðarbóli 39, 230 Reykjanesbæ

Meðstjórnandi: Ása V. Einarsdóttir, Baugholti 8, Reykjanesbæ

Meðstjórnandi: Jón Axelsson, Nónvörðu 11, 230 Reykjanesbæ

Meðstjórnandi: Ómar Steindórsson, Baugholti 9, 230 Reykjanesbæ

Meðstjórnandi: Dórunn Benediktsdóttir, Freyjuvöllum 6, 230 Reykjanesbæ

\section{Starfsemi 2014-2015}

Skrifstofa félagsins er opin priðjudaga og fimmtudaga kl 12-16 auk pess sem boðið er upp á viðtalstíma utan vinnutíma. Starfsmaðurinn, Sigrún Ólafsdóttir, er í 40\% starfi. Stjórnarfundir á tímabilinu voru tíu. Aðalfundur félagsins var haldinn 16. apríl 2015 og var með hefðbundnu sniði. Halldór Jónsson jr. bæklunarskurðlæknir flutti erindi um krabbamein í stoðkerfi.

Frá aðalfundi 2014 hefur orðið talsverð aukning á starfsemi félagsins og félögum hefur fjölgað umtalsvert. Eftir sumarfrí var hafist handa við að skipuleggja vetrarstarfið og undirbúa viðburði í október, bleika mánuðinum. Eins og áður hafa verið fastir fundir einu sinni í mánuði yfir vetrartímann par sem við höfum fengið áhugaverða fyrirlesara til okkar.

Í september fór fram haustsala krabbameinsfélaganna. Við tókum pátt í pví og eins og ávallt pegar við erum með fjáröflun notum við tækifærið og öflum nýrra félaga.

Í október var eins og undanfarin ár áherslan á konur og krabbamein og var ýmislegt um að vera. Fyrstu bleiku slaufuna fékk Helga Björk Steinpórsdóttir afhenta sem pakklæti fyrir gott starf fyrir félagið okkar. Margar byggingar voru lýstar bleikar og m.a. allar kirkjurnar á Suðurnesjum. Sunnudaginn 26. október var 
haldin bleik kvöldmessa í Keflavíkurkirkju tileinkuð konum og krabbameinum. Par voru konur í aðalhlutverkum með reynslusögu, ritningalestri og söng. Mánudaginn 3. nóvember var farin bleik ljósaganga sem var hugsuð fyrir alla fjölskylduna. Gengið var frá Holtaskóla að skógræktinni í Vatnsholti par sem boðið var upp á heitt súkkulaði, kex og sögustund við varðeld. Ævar Dór Benediktsson las úr hinni frábæru bók sinni „Dín eigin pjóðsaga“. Vel var mætt og veðrið var eins og best var á kosið. Ungliðar úr Björgunarsveitinni Suðurnes aðstoðuðu okkur við að klippa niður bleika filmu á ljósin og útdeildu súkkulaði og kexi. Með pessari göngu lukum við árlegu árvekniátaki varðandi krabbamein hjá konum.

Í marsfjáröfluninni seldum við heimagerða sultu merkta skeggmottu og félagsmerkinu okkar og vörur frá Raven design, kynntum félagið og öfluðum nýrra félaga. Sunnudaginn 22. mars var haldin blá kvöldmessa í Keflavíkurkirkju tileinkuð körlum og krabbameinum og nú voru pað karlar sem voru í aðalhlutverkum með frásögn, lestri og söng. Í mars var Keflavíkurkirkja lýst blá eins og í fyrra og einnig lýsti HS Orka sínar byggingar bláar til að minna á Mottumars körlum til heiðurs.

Nú á vormánuðum voru haldin tvö námskeið á vegum félagsins, annars vegar námskeið í hugrænni atferlismeðferð og hins vegar námskeið í qigong. Fullt var á bæði námskeiðin. Áfram fá peir sem greinst hafa með krabbamein frítt í jóga í Om-setrinu og á haustmánuðum náðum við að bæta við veigamiklum pætti í pá pjónustu sem við höfum getað veitt krabbameinssjúkum hér á svæðinu með pví að ganga frá samkomulagi við lögfræðistofu Suðurnesja um ókeypis lögfræðipjónustu fyrir okkar skjólstæðinga sem á pví purfa að halda.

Sigrún Ólafsdóttir.

\section{Krabbameinsfélag Hafnarfjarðar}

Stofnað: 10. apríl 1949.

Félagsmenn: Um 480.

Netfang: krabb@isl.is

Vefsíða: www.krabb.is/hafnarfjordur

Stjórn kosin á aðalfundi 15. apríl 2015:

Formaður: $\quad$ Anna Borg Harðardóttir, Skipalóni 18, 220 Hafnarfirði 6645851 annaborg@hafnarfjordur.is

Varaformaður: Hafrún Dóra Júlíusdóttir

Gjaldkeri: Jón Auðunn Jónsson, Klausturhvammi 9, 220 Hafnarfirði

Meðstjórnandi: Una Björk Harðardóttir, Lækjargötu 30, 220 Hafnarfirði

Meðstjórnandi: Gunnar Pór Jónsson

Meðstjórnandi: Magnús Gunnarsson

Meðstjórnandi: Ása Karin Hólm

\section{Starfsemi 2014-2015}

Á síðasta starfsári voru haldnir fimm stjórnarfundir á milli aðalfunda og sóttu varamenn pá til jafns við aðalmenn. Fundirnir voru haldnir í safnaðarheimili Hafnarfjarðarkirkju við Strandgötu og á Skipalóni 18. Aðalfundur félagsins var haldinn í sal í Hafnarfjarðarkirkju pann 28. apríl. Dagskrá var hefðbundin p.e. venjuleg aðalfundarstörf og önnur mál. Undir önnur mál voru sampykkt endurbætt lög félagsins. Fundinn sátu flestir stjórnarmenn en enginn félagsmaður mætti par fyrir utan. Helstu verkefnin á liðnu starfsári voru: pátttaka í Reykjarvíkurmaraboni, vinna við forvarnarverkefni gegn munntóbaki, formannafundir aðildarfélaganna og aðalfundur Krabbameinsfélags Íslands, fjárhagsstuðningur við ákveðin verkefni, bleiki mánuðurinn, skógarganga og mottumars.

Aðalfundur Krabbameinsfélags Íslands var haldinn laugardaginn 10. maí 2014 í Skógarhlíð og sóttu hann Anna Borg formaður og Hafrún Dóra varaformaður. Anna Borg sat formannafund aðildarfélaga Krabbameinsfélags Íslands sem að pessu sinni var haldinn laugardaginn 4. október 2014 á Akureyri. 
Anna Borg, Hafrún Dóra og Geir Bjarnason, forvarnarfulltrúi Hafnarfjarðar, hittust í ágúst 2014 til að fara yfir og undirbúa forvarnarstarfið gegn munntóbaki, í grunnskólum Hafnarfjarðar. Átakið fór síðan í gang í lok janúar 2015 og eins og nokkur undanfarin ár var gengið til samstarfs við Jón Ragnar Jónsson, ípróttamann og tónlistarmann, um að fara í alla 8. bekkina á skólaárinu. Í stuttu máli fór Jón í alla sjö skólana, par sem hann var eina kennslustund í hverjum bekk. Hann spjallaði við krakkana, sagði frá sínu lífi, ræddi heilbrigðan lífsstíl, talaði gegn munntóbaksnotkun og sagði frá tónlistarferlinum sínum og var með gítarinn í hönd og spilaði og söng. Skólastjórnendur og kennarar eru ákaflega ánægð og jákvæð fyrir pessu verkefni og eru farin að gera ráð fyrir bví inn í kennsluáætlun sína. Garðaskóli í Garðabæ fékk Jón Ragnar einnig til sín í ár og er bara vonandi að hann komist yfir fleiri skóla með petta flotta upplegg sitt gegn munntóbaksnotkun ungmenna. Petta átak er svo sannarlega að sýna árangur og má vísa í nýjustu niðurstöður frá Rannsóknir \& greining 2015 (niðurstöður rannsóknar meðal nemenda í 8., 9. og 10. bekk árið 2015) par sem færri og færri krakkar nota reglubundið munntóbak. Átakið gegn munntóbaksnotkun ungmenna er langhlaup sem fylgja verður vel eftir inn í framtíðina. Krabbameinsfélag Hafnarfjarðar sótti um styrk til verkefnisins, 550 púsund kr., í velunnarsjóð Krabbameinsfélags Íslands og fékk úthlutað 300 púsund krónum. Einnig var sótt um styrk frá Lýðheilsusjóði og fengum við úthlutað 200 púsund krónum til átaksins.

Dví miður hefur samstarf við ípróttafélögin, FH og Hauka, ekki gengið nógu vel eftir á liðnu starfsári. Félögin hafa ekki staðið við pau verkefni sem pó hafði verið sammælst um á vormánuðum 2014 og ekki sýnt pað frumkvæði að vera í sambandi við okkur um áframhaldandi samstarf. bessi staða verður væntanlega rædd á næsta starfsári.

Krabbameinsfélag Hafnarfjarðar var skráð hjá Reykjavíkurmaraponi og gátu hlauparar heitið á félagið, p.e. hver km gaf ákveðna krónutölu. Félagið fékk engin áheit að pessu sinni.

Kvöldganga í Höfðaskógi við Hvaleyrarvatn var farin priðjudaginn 23. september 2014 á vegum Krabbameinsfélags Hafnarfjarðar og Skógræktarfélags Hafnarfjarðar. Félagar og aðrir áhugasamir, fjölmenntu (rúmlega 50), við Gróðrastöðina Döll til að njóta skógarins í skjóli myrkurs og ganga saman í ævintýraljóma lukta. Gengið var um skóginn undir leiðsögn Steinars Björgvinssonar skógfræðings. Séra Jón Helgi Pórarinsson, prestur í Hafnarfjarðarkirkju, flutti hugvekju og Jóhann Guðni Reynisson, skáld með meiru, las upp frumsamin ljóð. Eftir gönguna var boðið upp á heitt súkkulaði og meðlæti í húsakynnum Dallar. Gangan tókst einstaklega vel og pátttakendur fóru sáttir og sælir heim eftir ævintýrlega upplifun um dimma skógarstíga. Stjórnarmenn voru pó sammála um varðandi næstu göngu, að leggja af stað hálftíma seinna eða um 19:30 til að gangan standi betur undir nafni í rökkrinu.

Í bleika mánuðinum stóðu Krabbameinsfélag Hafnarfjarðar, Krabbameinsfélag Reykjavíkur, Brjóstaheill Samhjálp kvenna og Ráðgjafarpjónustan fyrir sameiginlegu málpingi og pallborðsumræðum, undir yfirskriftinni: „Er besta pjónusta í boði?“.

Að venju fór Krabbameinsfélag Hafnarfjarðar í samstarf við bæjarstjóra og sóknarprest Hafnarfjarðarkirkju til að minna bæjarbúa á mikilvægi bleika mánaðarins. Fáni með bleiku slaufunni blakti út mánuðinn á fánastöng Ráðhússins og Hafnarfjarðarkirkjan var böðuð í bleiku ljósi. Að auki fór félagið í samstarf við hlaupahóp FH um að setja í gang „október-hlaupið“ og var pað svo sannarlega gert með glæsibrag og stemningu fyrir hlaupara og ekki hvað síst fyrir bæjarlífið. Hlaupið var til styrktar krabbameinssjúkum börnum og söfnuðust samtals 160 púsund krónur sem munu renna til stuðnings við krabbameinssjúk börn. Við gerð pessarar skýrslu standa yfir bréfaskriftir á milli Barnaspítala Hringsins og félagsins um pað í hvað nákvæmlega styrkurinn fer í. Eiga félagar í hlaupahóp FH hinar bestu pakkir fyrir frábæran stuðning. Í bleika mánuðinum var haft samband við Miðbæjarsamtökin og Hafnarborg um samvinnu um að gera bæinn bleikan. Pví miður tókst ekki að fylgja pessu almennilega eftir að pessu sinni en stefnt er að pví að taka upp práðinn haustið 2015, enda voru undirtektir jákvæðar.

Í mars hófst að venju átakið „Karlar og krabbamein - Mottumars“ á vegum Krabbameinsfélags Íslands. Hafnarfjarðarfélagið gerði sig áberandi í samfélaginu með pví að selja bæjarbúum armbönd og segulmottu til styrktar starfsemi félagsins. Stjórnarmenn stóðu í anddyri Fjarðarkaups föstudaginn 13. mars og laugardaginn 14. mars og seldu rúmlega 210 stykki. Heldur minni sala var í ár en mörg undanfarin ár og má par 
fyrst og fremst um kenna mjög slæmu veðri pessa helgina par sem fólk var hvatt til að vera heima vegna veðurs.

Á árinu styrkti Krabbameinsfélag Hafnarfjarðar Heilsugæslustöðina við Sólvang um kaup á öflugri myndavél til að mynda húðbletti. Styrkurinn hljóðaði upp á rúmar 100 púsund krónur.

Á formannafundinum á Akureyri í október 2014, tilkynnti Anna Borg fyrir hönd stjórnar, að Krabbameinsfélag Hafnarfjarðar legði til 100 púsund krónur í nýstofnaðan vísindasjóð Krabbameinsfélags Íslands. Stjórnin sampykkti jafnframt að leggja árlega til 200 krónur fyrir hvern félagsmann í sjóðinn.

Minningarkort félagsins eru seld á nokkrum stöðum hér í bænum og gefur pað félaginu nokkrar tekjur. Dau er einnig hægt að fá gegnum vefinn hjá Krabbameinsfélagi Íslands.

Sampykkt var á aðalfundi 2014 að félagsgjöld yrðu áfram 1.000 kr. fyrir almenna félagsmenn og 10.000 kr. fyrir styrktarfélaga og fyrirtæki. Stjórnin sá ekki ástæðu til hækkunar félagsgjalda.

Félagsmönnum fjölgaði lítillega á milli ára og eru nú um 483 talsins.

Krabbameinsfélag Hafnarfjarðar hefur sótti um tvo stóra styrki fyrir liðið starfsár, til að standa straum af kostnaði við átakið geng munntóbaki. Sótt var um styrk hjá Lýðheilsusjóði og fengum við eins og áður hefur komið fram 200 púsund krónur og hjá velunnarasjóði Krabbameinsfélags Íslands fengum við 300 púsund krónur. Stjórn félagsins er afskaplega pakklát fyrir pennan stuðning við átaksverkefnið.

Tilgangur Krabbameinsfélags Hafnarfjarðar hefur frá upphafi verið sá að styðja við baráttuna gegn krabbameini m.a. með fræðslu um krabbamein og krabbameinsvarnir, með styrkveitingu til ákveðinna verkefna og með stuðningi við krabbameinssjúklinga. Gildi forvarna er mjög mikilvægt t.d. varðandi munntóbaks- og tóbaksvarnir, mætingu í krabbameinsleit, mataræði og hreyfingu svo eitthvað sé nefnt. Petta eru atriði sem við purfum sífellt að vera að minna á. Krabbameinsfélag Hafnarfjarðar vill leggja sitt af mörkum til að hvetja fólk til að ástunda heilbrigða lífshætti og gerir bað með pví að vera sýnilegt í bæjarfélaginu og minna á pau verkefni sem eru í gangi hverju sinni í págu samfélagsins. •að er mikilvægt að missa ekki sjónar af tilgangi félagsins og pá sérstaklega pví sem snýr að forvörnum.

Anna Borg Harðardóttir.

\section{Brjóstaheill - Samhjálp kvenna}

Fullt nafn: Brjóstaheill - Samhjálp kvenna, til stuðnings konum sem greinast með brjóstakrabbamein. Stofnár: 1979 (sem formlegt félag sjálfboðaliða 2001).

Formlegir félagsmenn eru um 50 en um 350 fá fundarboð.

Netfang: samhjalp@krabb.is, vefsíða krabb.is/samhjalp, stuðningssími 8981712.

Stjórn kosin á aðalfundi 25. september 2014:

Formaður: $\quad$ Brynja Björk Gunnarsdóttir, Klapparbergi 2, Reykjavík 8947740 brynjagu@landspitali.is

Meðstjórnandi: Anna Sigríður Arnardóttir

Meðstjórnandi: Dóra Júliussen

Meðstjórnandi: Guðrún Sigurjónsdóttir

Meðstjórnandi: Hrefna Ingólfsdóttir

Meðstjórnandi: Jónína Jónsdóttir

Meðstjórnandi: Ragnheiður Guðmundsdóttir

\section{Starfsemi 2014-2015}

Alpjóðabrjóstaheilsudagurinn. Dann 15. október ár hvert er haldinn sérstakur dagur sem helgaður er baráttunni gegn brjóstakrabbameini. Dagurinn er haldinn í 46 löndum Evrópu undir merkjum Europa Donna. Í tilefni dagsins var gengið kringum Tjörnina undir merkjum Brjóstaheilla, Göngum saman, Krabbameinsfélags Íslands og Krabbameinsfélags Reykjavíkur. 
Málping um um konur og krabbamein var haldið mánudaginn 20. október á vegum Brjóstaheilla, Krabbameinsfélags Hafnarfjarðar, Krabbameinsfélags Reykjavíkur og Ráðgjafarpjónustu Krabbameinsfélagsins. Dema málpingsins var: „Er besta pjónusta í boði“. Fundarstjóri var Pórunn Sveinbjarnardóttir framkvæmdarstjóri. Ragnheiður Haraldsdóttir forstjóri setti málpingið. Helgi Sigurðsson prófessor og yfirlæknir lyflækninga krabbameina á Landspítala flutti erindið „Eru krabbameinslækningar á Íslandi í fallhættu?“ Gylfi Ólafsson heilsuhagfræðingur flutti erindið „Dýr og vandmeðfarin lyf, hver er innkaupastjórinn?“ Í lokin voru pallborðsumræður og pátttakendur voru Helgi Sigurðsson prófessor, Ófeigur Tryggvi Dorgeirsson læknir, Ragnheiður Haraldsdóttir forstjóri, Rannveig Einarsdóttir lyfjafræðingur og Dórunn Sævarsdóttir hjúkrunarfræðingur.

Ráðstefna um brjóstakrabbamein og BRCA-stökkbreytingar var haldin 1. og 2. nóvember 2014 á vegum DeCode í samráði við Brjóstaheill og Krabbameinsfélagið.

Jólafundur var haldinn í byrjun desember 2014. Kristján Skúli Ásgeirsson sérfræðingur í brjóstaskurðlækningum hélt fræðsluerindið „Skurðmeðferð brjóstakrabbameina á Íslandi, hvar stöndum við í dag og framtíðarsýn.“

Kastað til bata. Samhjálp kvenna og Krabbameinsfélagið hafa unnið sameiginlega að verkefninu „Kastað til bata“ og nú er verið að undirbúa pað í sjötta sinn. Dagana 4.-6. maí 2015 býðst 14 konum sem greinst hafa með brjóstakrabbamein, að fara í laxveiði í Laxá í Kjós undir stjórn prautreyndra veiðimanna sem leiðbeina konunum við veiðina. Einnig eru með í för konur frá Brjóstaheillum konunum til stuðnings. bessar ferðir hafa tekist með eindæmum vel og hafa konurnar sem farið hafa haldið hópinn og stutt hver aðra áfram.

Erlent samstarf. prjár konur frá Brjóstaheillum sóttu ráðstefnu norrænu brjóstakrabbameinsfélaganna 12.-14. september sl. sem haldin var í Osló og er fyrirhugað að halda norrænu ráðstefnuna á Íslandi í september 2016. Brjóstaheill er í Europa Donna og starfar með samtökunum. Tveir fulltrúar, Anna Sigríður Arnardóttir lögfræðingur og stjórnarkona í Brjóstaheillum og Fjóla Viggósdóttir brjóstahjúkrunarfræðingur á brjóstamóttöku Landspítalans, sóttu sjálfboðaliðanámskeið Europa Donna í Mílanó í nóvember 2014.

Brynja Björk Gunnarsdóttir.

\section{Framför}

Stofndagur: 12. febrúar 2007. Félagsmenn: 25.

Vefsíða framfor.is

Stjórn:

Formaður: Guðmundur Örn Jóhannsson

Gjaldkeri: Hinrik Greipsson

Meðstjórnandi: Einar Benediktsson

Meðstjórnandi: Hrafn Pálsson

Meðstjórnandi: Jón G. Ingvason

\section{Starfsemi 2013-2014}

Helstu verkefni: Safnað fyrir nýjum línuhraðli, styrkir sóttir til fyrirtækja og páskaegg seld til fyrirtækja.

Guðmundur Örn Jóhannsson. 


\section{Kraftur}

Fullt nafn: Kraftur, stuðningsfélag fyrir ungt fólk sem greinst hefur með krabbamein

og aðstandendur.

Stofndagur: 1. október 1999. Félagsmenn: Um 510.

Netfang kraftur@kraftur.org, vefsíða www.kraftur.org

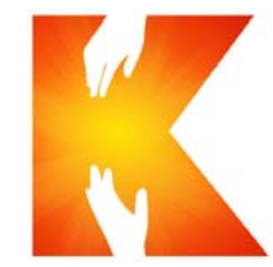

Stjórn Krafts, kosin á aðalfundi 29. apríl 2015:

Formaður: Hulda Hjálmarsdóttir

Meðstjórnandi: Ástrós Rut Sigurðardóttir

Meðstjórnandi: Pórir Ármann Valdimarsson

Meðstjórnandi: Svanhildur Ásta Haig

Meðstjórnandi: Ólafur Einarsson

\section{Starfsemi 2014-2015}

Stjórn o.fl. Miklar breytingar áttu sér stað á stjórn Krafts á aðalfundi félagsins pann 29. apríl sl. Halldóra Víðisdóttir gaf ekki kost á sér áfram sem formaður og var Hulda Hjálmarsdóttir kjörin formaður til næstu tveggja ára. Julie Coadou og Sigríður Margrét Einarsdóttir gáfu ekki kost á sér til áframhaldandi stjórnarsetu. prír fulltrúar voru kosnir í aðalstjórn og tveir í varastjórn.

Starfsmenn. Starfsmaður Krafts er Ragnheiður Davíðsdóttir, sem hefur gegnt starfi framkvæmdastjóra frá 1. september 2013. Anna Sigríður Jökulsdóttir lét af starfi sálfræðings sl. haust og við tók Lilja Sif Dorsteinsdóttir. Hún sér um Stuðningsnet Krafts og sálfræðipjónustu við félagsmenn Krafts og skjólstæðinga Ráðgjafarbjónustunnar. Auk pess hélt hún námskeið fyrir nýja stuðningsfulltrúa snemma á pessu ári. Starfsmaður Ungliðahóps Krafts, Styrktarfélag krabbameinssjúkra barna (SKB) og Ljóssins er Kristján Friðriksson. Starfsmaður Fítonskrafts er Atli Már Sveinsson, ípróttafræðingur.

Stuðningsnetið. Á árinu var haldið eitt stuðningsfulltrúanámskeið. Kraftur hélt áfram að efla Stuðningsnetið og er ætlunin að halda stuðningsfulltrúanámskeið á landsbyggðinni á pessu ári. Kraftur fékk styrk frá velferðarráðuneytinu sérstaklega til útbreiðslu stuðningsnetsins. Hulda Hjálmarsdóttir hefur gert rannsókn á áhrifum stuðningsnetsins og er pað verkefni hennar til BS-prófs í sálfræði við HÍ. Niðurstöður peirrar rannsóknar hafa ekki enn verið birtar en ljóst er pó að pær lofa góðu og eru jákvæðar í garð starfseminnar og verða notaðar til pess að efla Stuðningsnet Krafts enn frekar.

Heimasíða og samfélagsmiðlar. Reglulega er settar fréttir, myndir og fróðleikur inn á www.kraftur.org. Ný heimasíða var tekin í notkun á síðasta ári sem hefur fallið í góðan jarðveg. Facebook-síða Krafts er talsvert mikið notuð og skrá félagsmenn sig gjarnan á viðburði félagsins á síðunni. Nú eru fylgjendur Facebook síðu félagsins um 1.650 að tölu. Pá hefur félagið sett á laggirnar Facebook-síðu Fítonskrafts par sem fréttir eru reglulega settar inn og tilkynningar um starfsemina. Auk pess eru sérstakar Facebook-síður starfræktar á vegum Ungliðahópsins og Stuðningsnetsins.

Útgáfumál. Bókin Lífs-Kraftur, hagnýtar upplýsingar fyrir pá sem greinst hafa með krabbamein og aðstandendur, var gefin út í fjórða sinn á síðasta ári. Bókin nýtur alltaf jafn mikilla vinsælda og er regluleg eftirspurn eftir henni í heilbrigðiskerfinu og víðar. Krafts-blaðið var gefið út síðasta haust og var um að ræða sérstaka viðhafnarútgáfu í tilefni 15 ára afmælis félagsins og kom pað í stað peirra tveggja blaða sem jafnan eru gefin út árlega. Lilja Sif porsteinsdóttir, sálfræðingur, skrifaði texta í bækling um viðbrögð við áföllum og er honum dreift sem víðast til peirra sem á purfa að halda. Kraftur gaf út bókina „Đegar foreldri fær krabbamein“ sem er býdd bók eftir Wendy S. Harpham, lækni. Bókin er seld í bókabúðum á vegum Forlagsins en Kraftur fékk 100 höfundareintök sem seld hafa verið frá skrifstofu félagsins í fjáröflunarskyni. раð var fyrirtækið Gengur vel sem styrkti útgáfuna.

Fjármál og styrkir. Efnahagur Krafts er traustur. Umfangsmesta verkefnið sem Kraftur stóð fyrir á síðasta ári var stofnun Neyðarjóðs Krafts. Nú er verið að úthluta fyrstu styrkjunum úr sjóðnum en úthutað verður vor og 
haust. Lögð var mikil vinna í markaðsstarf, bæði í fjölmiðlum og eins á netinu. Reykjavíkurmarabon var haldið í ágúst. Heildarafrakstur af áheitum einstaklinga færðu félaginu tæplega tvær milljónir króna. bá seldi Kraftur konfekt fyrir jólin sem gaf félaginu 640 púsund í hagnað. Auglýsingar og styrktarlínur voru seldar í blaðið og stóð sú sala undir kostnaði pess og gott betur. Ýmsir aðilar styrktu starfsemina með beinum hætti og má par nefna fyrirtæki sem ákváðu að senda ekki jólakort en gefa Krafti fjármuni sem ella hefði verið varið í pað, ágóða tónleika sem kórar héldu, framlög frá nemendafélögum framhaldsskóla, söfnun á vinnustöðum og fl. Birt var opnuauglýsing í Fréttablaðinu par sem framlög til Reykjavíkurmaraponsins voru pökkuð og fengust ágætar tekjur af pví.

Viðburðir. Árið 2014 var einstaklega viðburðarríkt í sögu félagsins enda hélt félagið uppá 15 ára afmæli sitt. Eins og áður er getið um var gefið út veglegt afmælisblað auk pess sem haldnir voru styrktartónleikar í Hörpu og afmælismálbing á afmælisdegi félagsins pann 1. október sem bar yfirskriftina „Ungt fólk og krabbamein“. Styrktartónleikarnir voru afar vel heppnaðir en par komu fram pekktir listamenn sem allir gáfu vinnu sína. Atlantssolía var aðalstyrktaraðili tónleikanna en fjölmargir aðrir styrktaraðilar komu að peim á einn eða annan hátt. Uppselt var á tónleikana og komust færri að en vildu. Allur ágóði peirra, tvær milljónir, rann óskiptur í Neyðarsjóð Krafts. Sumargrill Krafts var haldið í júní í Hellisgerði í Hafnarfirði og mættu um 70 manns. Vísindaferðir Krafts eru vinsælar meðal háskólanema en í peim er starfsemi Krafts kynnt, sérstaklega fjallað um stuðningsnetið auk pess sem fenginn er fagmaður úr viðkomandi grein til að miðla af reynslu sinni. Í byrjun desember var haldin jólastund félagsins. Par mætti hljómsveitin Dúndurfréttir og skemmti viðstöddum auk pess sem lesið var upp úr jólabók og dregið í veglegu happdrætti. Fyrirtækið Dalpay gerði Krafti kleift að bjóða upp á Dúndurfréttir og fjölmargir aðilar styrktu Kraft með happdrættisvinningum. Um sjötíu manns mættu á jólastundina. Fítonskraftur, endurhæfingar-, íprótta- og útivistarhópur á vegum Krafts var stofnaður á árinu. Detta er samstarfsverkefni Krafts og Ráðgjafarbjónustunnar og fékkst styrkur frá Sorpu til pess að hrinda pessu verkefni, sem er tilraunaverkefni til sex mánaða, af stað. Atli Sveinsson, ípróttafræðingur með sérmenntun í endurhæfingu krabbameinsgreindra, hefur umsjón með Fítonskrafti.

Ragnheiður Davíðsdóttir.

\section{Ný rödd}

Fullt nafn: Ný rödd, samtök fólks sem hefur misst raddbönd vegna krabbameins.

Stofndagur: 20. desember 1980. Félagsmenn: Um 20.

Netfang: nyrodd@krabb.is Vefsíða: www.krabb.is/nyrodd

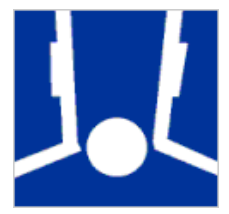

Stjórn kosin á aðalfundi 3. mars 2015:

Formaður: $\quad$ Ragnar Davíðsson, Gnoðavogi 74, 104 Reykjavík $\quad 6931426$ ragnar@rikiskaup.is

Meðstjórnandi: Jón Erlendur Guðmundsson

Meðstjórnandi: Stefán Kr. Sverrisson

\section{Starfsemi 2014-2015}

Ný rödd er stuðningsfélag peirra sem misst hafa raddbönd og barkakýli vegna krabbameins. Heimsóknir til sjúklinga fyrir og eftir aðgerðir og jafningjafræðsla eru fastir liðir í starfseminni, en gott samstarf hefur tekist á milli félagsins og háls-, nef- og eyrnadeildar Landspítalans, sem og talmeinafræðinga. Félagsfundir eru haldnir með líku sniði og fyrri ár og fundað að jafnaði á tveggja mánaða fresti. Ný rödd hefur notið velvildar krabbameinsfélaganna og tekið pátt í formannafundi og aðalfundi Krabbameinsfélags Íslands.

Fulltrúar frá Nýrri rödd hafa í gegnum tíðina sótt norrænnar ráðstefnur systurfélaga sinna á Norðurlöndum par sem kynntar eru helstu nýjungar í hjálpartækjum barkakýlislausra auk pess sem rætt er um framfarir í lækningum og aðgerðum sem vænta má á næstu árum.

Á aðalfundi í mars 2015 var sampykkt að sækja um aðild að Öryrkjabandalagi Íslands. 


\section{Ristilfélagið}

Stofndagur: 30. júní 2009.

Félagsmenn: Um 65.

Vefsíða: krabb.is/ristilfelagid

Stjórn kosin á aðalfundi 3. mars 2015:

Formaður: Páll Sævar Guðjónsson

8978103 psg@tandur.is

Meðstjórnandi: Gunnhildur Sigurðardóttir

Meðstjórnandi: Helena Eydís Ingólfsdóttir

Meðstjórnandi: Magnea Guðmundsdóttir

Meðstjórnandi: Dorleifur Guðmundsson

\section{Starfsemi 2014-2015}

Tilgangur félagsins er að vinna að hagsmunum peirra sem greinst hafa með sjúkdóminn og kynningu á málefnum peirra svo og að beita sér fyrir pví að hafin verði leit að ristil- og endaparmskrabbameini á byrjunarstigi. Félagið hefur tekið pátt í samstarfshópi um fræðslumál o.fl.

Á aðalfundinum í vor var mikill hugur í fundarmönnum og er stefnt að aukinni starfsemi.

Páll Scevar Guðjónsson.

\section{Stómasamtök Íslands}

Stofndagur: 16. október 1980. Félagsmenn: 300.

Netfang: stoma@stoma.is

Vefsíða: www.stoma.is

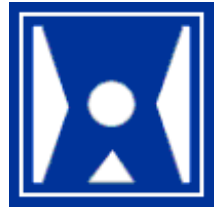

Stjórn kosin á aðalfundi 2015:

Formaður: Jón Dorkelsson, Miðvangi 121, 220 Hafnarfirði

Meðstjórnandi: Eva Bergmann

Meðstjórnandi: Inger Rós Jónsdóttir

Meðstjórnandi: Kristján Freyr Helgason

Meðstjórnandi: Sigurður Jón Ólafsson

\section{Starfsemi 2014-2015}

Starfsárið var með hefðbundnu sniði hjá félaginu. Haldnir voru sex almennir félagsfundir á starfsárinu og voru peir sem hér segir: Almennir félagsfundir voru haldnir fyrsta fimmtudag í hverjum mánuði frá október til apríl að janúar mánuði undanskildum. Almennur fundur var haldinn á Akureyri í maí. Aðalfundur félagsins var síðan haldinn í maí eins og lög félagsins segja til um. Ungir stómapegar hittust nokkrum sinnum óformlega yfir árið.

Innlent samstarf. Stjórnarmenn sóttu fundi í nefndum og ráđum innan Krabbameinsfélags Íslands eftir pví sem efni og ástæður gáfu tilefni til. Einnig á formaður sæti í stjórn Krabbameinsfélagsins og fjáröflunarráði pess. Fulltrúi félagsins á síðan sæti í aðalstjórn Öryrkjabandalagins og sótti par fundi reglulega auk pess sem sem prír fulltrúar samtakanna sóttu aðalfund Öryrkjabandalagsins. Einnig var formaður samtakanna kosinn til setu í kjörnefnd Öryrkjabandalagsins fjórða árið í röð. Sömuleiðis var haldinn sameiginlegur fundur með CCU-samtökunum.

Erlent samstarf. Nokkrar sendingar af afskrifuðum stómavarningi fóru til Úkraínu en undir pað síðasta urðu tafir á frekari sendingum vegna ástandsins par. Einnig aðstoðuðum við sænsku samtökin (ILCO) við starf í Zimbabwe en Svíar eru par með hjálparstarf í gangi. Formaður samtakanna var áfram í stjórn Evrópusam- 
takanna, EOA, og tók pátt í stjórnarstörfum. Norræn ráđstefna var haldin í Reykjavík í september síðastliðnum og tókst mjög vel prátt fyrir fjarveru Norðmanna.

Útgáfumál. Fréttablað Stómasamtakanna var gefið út samkvæmt venju, kom út fimm sinnum og er sem fyrr undir ritstjórn Sigurðar Jóns Ólafssonar. Fréttabréfin er einnig að finna á pdf-formi á heimasíðu samtakanna, www.stoma.is. Endurhönnun á heimasíðu félagsins hófst síðan núna snemma á vordögum og hefur gengið nokkuð vel fyrir sig. Smávægileg fínpússning á verkinu er ennpá eftir en heimasíðan lítur orðið mjög vel út og ætti hún að nýtast vel á næstu árum.

Almennt. Í lok starfsársins voru félagsmenn um 300 talsins, flestir á höfuðborgarsvæðinu en einnig er stór hópur virkur á Eyjafjarðarsvæðinu. Fjárhagur félagsins er ágætur í lok starfsársins. Ítrekað hefur verið reynt að fá styrki til starfseminnar víða að en pað gengur mjög illa nema kannski helst á hefðbundnum slóðum innan Krabbameinsfélagsins og Öryrkjabandalagsins.

Jón Porkelsson.

\section{Styrkur}

Fullt nafn: Styrkur, samtök krabbameinssjúklinga og aðstandenda peirra.

Stofndagur: 20. október 1987. Félagsmenn: Um 350.

Netfang: styrkur@krabb.is Vefsíða: www.krabb.is/styrkur

Stjórn kosin á aðalfundi 15. maí 2014:

Formaður: $\quad$ Steinunn H. Friðriksdóttir, Austurströnd 12, 170 Seltj.

Varaformaður: Hólmfríður Friðriksdóttir, Kaplaskjólsvegi 93, 107 R.

Meðstjórnandi: Bertha Biering

Meðstjórnandi: Bryndís Konráðsdóttir

Meðstjórnandi: Snorri Ingimarsson

Meðstjórnandi: Erna Nielsen

Meðstjórnandi: prúður Hjaltadóttir

\section{Starfsemi 2014-2015}

Formaður og varaformaður sátu aðalfund Krabbameinsfélags Íslands í maí og formaður formannafund á Akureyri í október. Fjáröflun var í september með aðstoð Lionsfélaga í Eir og fimleikahóps telpna í Gróttu á Seltjarnarnesi og félaga í Styrk. Salan gekk vel, seldir voru pennar, spil og málbönd. Jólakort með myndum eftir Kristínu Gunnlaugsdóttur voru seld í desember.

Sú breyting var gerð á fundardögum að við færðum okkur yfir á mánudaga. Fundir eru nú haldnir annan mánudag í mánuði, eins og við vorum upphaflega, en kl. 17 í stað kl. 20.

Hrönn Harðardóttir lungnasérfræðingur kom til okkar í nóvember ásamt Gunnari Bjarna Ragnarssyni krabbameinslækni. Rætt var um reykingar, hættur og afleiðingar. Jólafundur var í desember. Hildur Friðriksdóttir blaðamaður flutti jólahugvekju, Ragnar Jónasson og Porgrímur práinsson lásu úr bókum sínum, Marta Kristín Friðriksdóttir nemi gladdi okkur með frábærum söng og glæsileik. Boðið var upp á heitt súkkulaði, jólatertur og kökur.

Á opnu húsi í janúar las Eyrún Ósk Jónsdóttir rithöfundur og leikstjóri úr bókum sínum söngur Snáksins og Lórelei, ævintýri um ástina. Dorrablót var í febrúar, matur frá Múlakaffi að venju. Markús Dórhallsson sagnfræðingur sagði frá íslenskri kvennhetju. Dansnemar sýndu okkur danssporin á heimsvísu. Maja, Valli og Jón sungu og spiluðu. Félagsfundir voru í mars og apríl.

Steinunn Helga Friðriksdóttir. 


\section{Lög Krabbameinsfélags Íslands}

\section{1. gr. Nafn og skilgreining.}

Félagið heitir Krabbameinsfélag Íslands. Aðild að pví eiga krabbameinsfélög í landinu og önnur áhugamannasamtök sem starfa í samræmi við tilgang félagsins og hlotið hafa sampykki stjórnar pess og staðfestingu aðalfundar.

Heimili félagsins og varnarping er í Reykjavík.

\section{2. gr. Tilgangur.}

Tilgangur félagsins er að styðja og efla í hvívetna baráttuna gegn krabbameini, svo sem með pví að:

1. Beita sér fyrir virkri opinberri stefnu (krabbameinsáætlun) í forvörnum, greiningu, meðferð og endurhæfingu peirra sem greinast með krabbamein.

2. Stuðla að pekkingu og menntun um krabbamein og krabbameinsvarnir.

3. Efla krabbameinsrannsóknir, m.a. með söfnun og vísindalegri úrvinnslu upplýsinga og með rekstri vísindasjóðs.

4. Beita sér fyrir leit að krabbameini á byrjunarstigi.

5. Styðja framfarir í meðferð krabbameins og umönnun krabbameinssjúklinga.

6. Beita sér fyrir stuðningi við krabbameinssjúklinga og aðstandendur.

7. Vera málsvari krabbameinssjúklinga og beita sér fyrir réttindum peirra.

\section{3. gr. Stjórnun.}

Æðsta vald í málefnum félagsins er í höndum aðalfundar, sem haldinn skal fyrir maílok ár hvert. Boða skal til hans bréflega með a.m.k. mánaðar fyrirvara. Fundurinn er lögmætur ef löglega er til hans boðað.

Á aðalfundi skulu tekin fyrir pessi mál:

1. Skýrsla stjórnar fyrir síðastliðið starfsár.

2. Endurskoðaðir reikningar félagsins lagðir fram til sampykktar.

3. Skýrslur aðildarfélaga.

4. Lagabreytingar.

5. Stjórnarkjör.

6. Kosnir tveir endurskoðendur og einn til vara.

7. Kosnir fimm menn í uppstillingarnefnd.

8. Önnur mál.

Hverju starfandi aðildarfélagi er heimilt að senda einn fulltrúa á aðalfund fyrir hverja 200 félagsmenn, eða brot úr peim fjölda, pó aldrei fleiri en sex fulltrúa. Jafnframt hafa stjórnarmenn Krabbameinsfélags Íslands fulltrúarétt á aðalfundi.

Stjórn félagsins hefur æðsta vald í málefnum félagsins á milli aðalfunda. Stjórnin er skipuð sjö aðalmönnum og tveim til vara. Formaður skal kosinn sérstaklega til tveggja ára í senn. Árlega skal kjósa prjá meðstjórnendur til tveggja ára og tvo til vara til eins árs í senn. Við skipan stjórnar skal pess gætt að fulltrúar séu bæði frá svæðafélögum og stuðningshópum. Miðað er við að stjórnarmenn sitji að jafnaði eigi lengur en fjögur kjörtímabil í senn. Á fyrsta stjórnarfundi eftir aðalfund kýs stjórnin úr sínum hópi varaformann, ritara og gjaldkera.

Formaður boðar til stjórnarfunda að jafnaði mánaðarlega. Stjórnarfund skal kalla saman ef prír stjórnarmenn eða fleiri óska pess. 
Formannafundur skal að jafnaði haldinn í október. Par skulu kynnt pau málefni sem unnið er að á vegum félagsins á hverjum tíma. Tillögur sampykktar á formannafundi skulu vera bindandi fyrir stjórn, enda skulu pær hljóta meirihluta greiddra atkvæða peirra sem hefðu haft atkvæðisrétt á síðasta aðalfundi.

4. gr. Rekstur.

Stjórn félagsins ræður forstjóra sem ber ábyrgð á rekstri félagsins gagnvart stjórninni, samkvæmt starfslýsingu.

Stjórnin setur reglur um starfsemi félagsins.

\section{5. gr. Fjármál.}

Aðildarfélög skulu hafa samráð við stjórn áður en stofnað er til meiri háttar fjáröflunar.

Reikningsár félagsins er almanaksárið.

6. gr. Lagabreytingar.

Tillögur um lagabreytingar skulu sendar formanni minnst tveimur mánuðum fyrir aðalfund. Skulu pær kynntar í fundarboði.

Til breytinga á lögum félagsins parf 3/5 greiddra atkvæða á aðalfundi.

Aldrei má breyta lögunum pannig að raskað sé megintilgangi félagsins skv. 2. grein.

7. gr. Félagsslit.

Til að leggja félagið niður parf sampykki tveggja aðalfunda í röð og séu félagsslitin sampykkt með a.m.k. 4/5 greiddra atkvæða á hvorum fundi. Geta skal sérstaklega áforms um félagsslit í fundarboði.

Verði félagið lagt niður skal eignum pess ráðstafað til líknarstarfa í samráði við heilbrigðisráðuneytið. pví ákvæði má aldrei breyta.

Lögin í heild voru sampykkt á aðalfundi 6. maí 2000, breyting á 3. grein (uppstillingarnefnd) á aðalfundi 3. maí 2003 breyting á 2. grein (vísindasjóður) og 3. grein (formannafundur) á aðalfundi 7. maí 2005 og breyting á 2. gr. (1., 6. og 7. töluliður) á aðalfundi 7. maí 2011. 

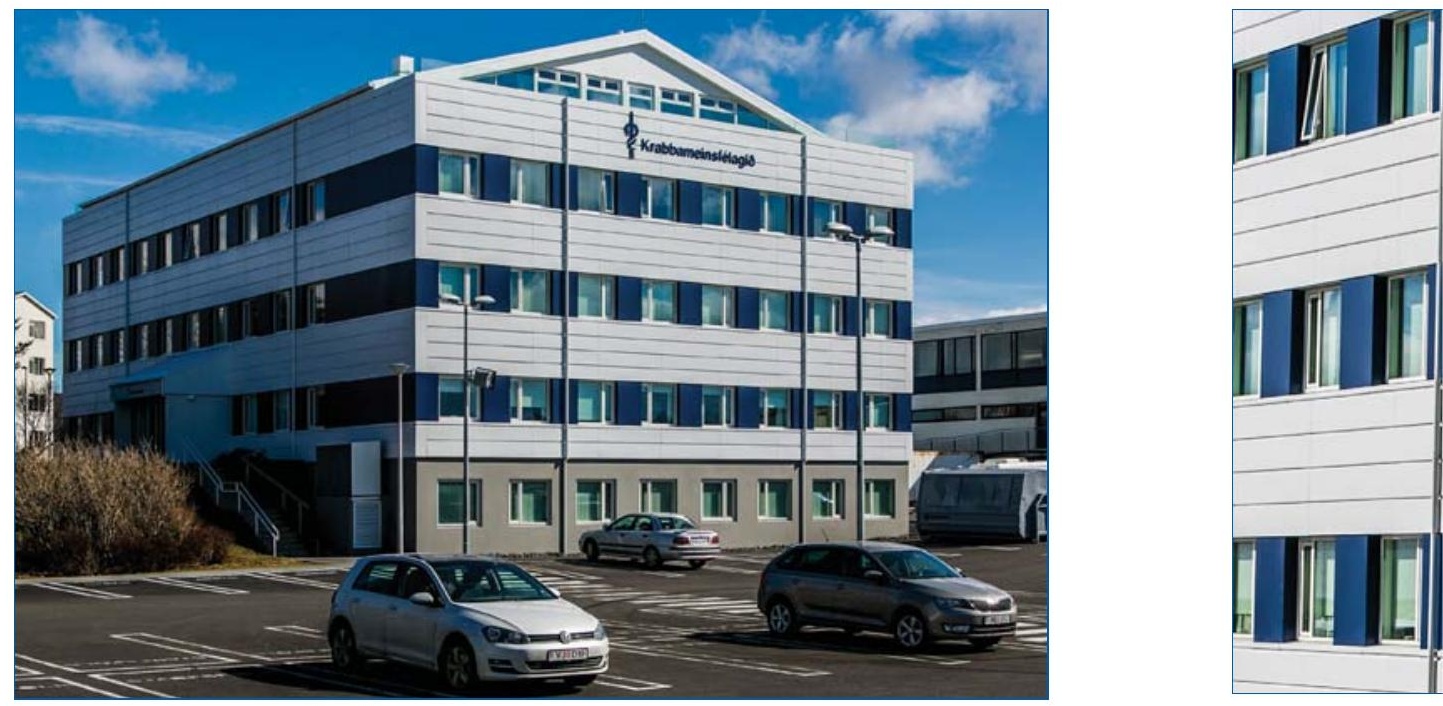

Krabbameinsfélagiô 